\title{
110th Anniversary: Carbon Dioxide and Chemical Looping: Current Research Trends
}

\author{
Lukas C. Buelens, Hilde Poelman, Guy B. Marin, ${ }^{(0)}$ and Vladimir V. Galvita*(0) \\ Laboratory for Chemical Technology, Ghent University, Technologiepark 125, B-9052 Ghent, Belgium \\ Supporting Information
}

ABSTRACT: Driven by the need to develop technologies for converting $\mathrm{CO}_{2}$, an extraordinary array of chemical looping based process concepts has been proposed and researched over the past 15 years. This review aims at providing first a historical context of the molecule $\mathrm{CO}_{2}$, which sits at the center of these developments. Then, different types of chemical looping related to $\mathrm{CO}_{2}$ are addressed, with attention to process concepts, looping materials, and reactor configurations. Herein, focus lies on the direct conversion of carbon dioxide into carbon monoxide, a process deemed to have economic potential.

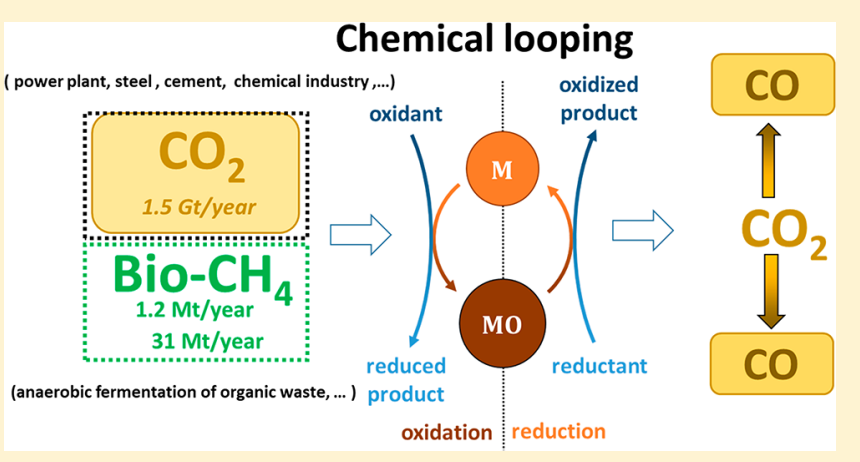

designate $\mathrm{CO}_{2}$ and $\mathrm{CO}$ probably occurred only after the foundation of the International Union on Pure and Applied Chemistry (IUPAC) in 1919.

\section{CARBON DIOXIDE AND THE EARTH'S CLIMATE}

In the 1820s, Joseph Fourier made heat transfer calculationsbased on knowledge of that time-between the Sun and the Earth. ${ }^{9,10}$ On the basis of his calculations, however, Fourier was unable to explain why the Earth's surface temperature was so high. ${ }^{9,10}$ Among other possible explanations, Fourier proposed that the Earth's atmosphere could be partially responsible for keeping the surface warm. ${ }^{9}$ In the early 1860 s, John Tyndall ${ }^{11}$ first proved the greenhouse effect, the heat insulating effect of the atmosphere owing to the presence of absorbing and radiating "greenhouse" gases such as water $\left(\mathrm{H}_{2} \mathrm{O}\right)$, carbon dioxide $\left(\mathrm{CO}_{2}\right)$ and methane $\left(\mathrm{CH}_{4}\right)$. Tyndall correctly measured the relative infrared absorptive powers of different gases present in the atmosphere (nitrogen, oxygen, water vapor, carbon dioxide, ozone, methane, among others). ${ }^{11}$

In 1896, Svante Arrhenius was the first to quantitatively estimate the relation between atmospheric $\mathrm{CO}_{2}$ concentration and the Earth's surface temperature based on physical chemistry. ${ }^{12,13}$ From his calculations, Arrhenius concluded that human-caused $\mathrm{CO}_{2}$ emissions through the combustion of carbonaceous fuels could be large enough to significantly affect the Earth's climate through the greenhouse effect. ${ }^{12,13}$ In 1931, Edward O. Hulburt confirmed Arrhenius' theory and estimated that a doubling and tripling of the $\mathrm{CO}_{2}$ levels in the atmosphere would result in an increased surface temperature

Received: May 7, 2019

Revised: July 11, 2019

Accepted: July 18, 2019

Published: July 18, 2019 
of 4 and $7 \mathrm{~K}$, while the opposite would hold for cooling due to a decrease in $\mathrm{CO}_{2}$ levels. ${ }^{14}$ With his work, published in 1938, Guy S. Callendar was probably the first to report the evolution in the Earth's average surface temperature since 1880 based on collected data from different measurement stations. ${ }^{15}$ Callendar proposed that the observed increase in average temperature could be owing to accumulation of anthropogenic $\mathrm{CO}_{2}$ emissions into the atmosphere. ${ }^{15}$

The discussion with respect to the effect of anthropogenic $\mathrm{CO}_{2}$ upon the Earth's climate was revived by Gilbert N. Plass in $1956 .^{16}$ Plass estimated that global atmospheric $\mathrm{CO}_{2}$ concentrations increased with about $30 \%$ per century and resulted in an average temperature increase of $1.1 \mathrm{~K}$ per century. ${ }^{16}$ Moreover, he calculated that doubling the levels of $\mathrm{CO}_{2}$ would cause an average temperature increase of $3.6 \mathrm{~K} .{ }^{16}$ One year later, in 1957, Roger Revelle and Hans E. Suess published their findings with respect to the role of the oceans as $\mathrm{CO}_{2}$ sinks. ${ }^{17}$ Contrary to what had previously been assumed, Revelle and Suess found that the average residence time of $\mathrm{CO}_{2}$ in the atmosphere before being absorbed in the ocean is of the order of 10 years rather than hundreds of years. ${ }^{17}$ They initially contested earlier propositions that linked the rise in the Earth's surface temperature with an (unproven) increase in atmospheric $\mathrm{CO}_{2}$ concentration. ${ }^{17}$ Revelle and Suess argued that this would be unlikely because most of the anthropogenic $\mathrm{CO}_{2}$ - produced by combustion of fossil fuels since the beginning of the industrial revolution-would have been absorbed by the ocean. ${ }^{17}$ While detailed measurements of the global temperature had started around 1850, ${ }^{18}$ Charles D. Keeling started performing measurements of the atmospheric $\mathrm{CO}_{2}$ concentration in $1958 .^{19}$

In the 1960s and 1970s, many new models and estimates of climate sensitivity to $\mathrm{CO}_{2}$ levels were proposed and showed a strongly varying outcome, causing quite some climate confusion. $^{20}$ The model used by Syukuro Manabe and Richard T. Wetherald in their 1967 publication, ${ }^{21}$ however, was exceptional in that it included all the major occurring physical phenomena (including convection and conduction) while taking into account temperatures at the Earth's surface and in the atmosphere. Indeed, their model, which predicted an average temperature rise of 1.5 to $2.4 \mathrm{~K}$ upon a doubling of the atmospheric $\mathrm{CO}_{2}$ concentration, could be considered the first true meteorological model.

From 1968 , $^{2-24}$ Keeling started publishing the evolution of his atmospheric $\mathrm{CO}_{2}$ concentration measurements, which had steadily increased from 312 to $318 \mathrm{ppm}$ since 1958. In order to acquire temperature data prior to 1850 and $\mathrm{CO}_{2}$ concentration levels before 1958, researchers started studying tree ring cores $^{25-30}$ and ice cores, ${ }^{30-36}$ while developing techniques to accurately obtain climate information by calibration with reliable direct measurements. During the 1980s, efforts in raising awareness about climate change in the US were orchestrated by scientists and activists such as Gordon MacDonald, Rafe Pomerance, and James Hansen. ${ }^{37}$ Although their efforts remained largely unanswered by political leaders, the perseverance of Pomerance and Hansen in particular certainly contributed to the establishment of the International Panel on Climate Change (IPCC) in 1988. ${ }^{37}$ Additional historical context to the relationship between $\mathrm{CO}_{2}$ and the environment is provided in Supporting Information (Historical Context 1).

Current trends in global climate monitoring include the analysis of data recorded by satellites. ${ }^{38-40}$ At the same time, climate modeling has tremendously evolved in the past decades with "Earth System Models" (ESMs) as the current state of the art. $^{41}$ Nevertheless, capturing and modeling the complexity of the Earth's climate remains a huge task as it essentially encompasses comprehending the (physical) chemistry, geology (e.g., effect of volcanic activity), and fluid dynamics of the Earth, as well as the occurrence and influence of processes occurring in the Sun.

After the first IPCC report was published in the 1990s, awareness within the scientific community has grown tremendously. Today, a large majority of the scientific community, estimated at over $95 \%,{ }^{42}$ acknowledges that anthropogenic greenhouse gas (such as $\mathrm{CO}_{2}$ and $\mathrm{CH}_{4}$ ) emissions have a significant effect on the Earth's climate. ${ }^{43}$ Nevertheless, this scientific consensus is not necessarily picked up outside the scientific community, especially in Anglo-Saxon countries. $^{43,44}$

Apart from purely environmental concerns, the presence of excessive amounts of $\mathrm{CO}_{2}$ in the atmosphere is increasingly approached from a geo-engineering perspective, i.e., by aiming to obtain deliberate control over the environment. Accordingly, trends in research and development focus on reducing $\mathrm{CO}_{2}$ emissions by its capture, (geological) storage, or recycling and the active control of atmospheric $\mathrm{CO}_{2}$ levels.

The evolution in carbon dioxide research trends can be illustrated by the number of publications treating certain topics, shown in Figure 1. It can be seen that a stagnating

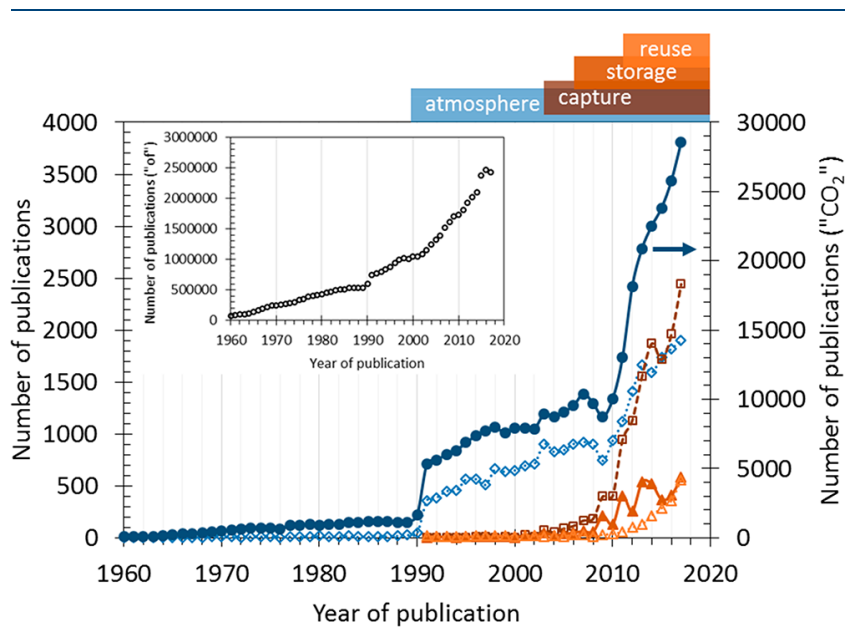

Figure 1. Overview of the evolution of number of scientific publications for different topics. The evolution of the number of scientific publications (Web of Science online database) per year filtered by different keywords is presented. These topical keywords are the following: (๑) " $\mathrm{CO}_{2}$ "; $(\diamond)$ " $\mathrm{CO}_{2}$ " $\mathrm{AND}$ "atmosphere" (atmosphere); ( $\square$ ) " $\mathrm{CO}_{2}$ capture" (capture); ( $\left.\mathbf{\Delta}\right)$ " $\mathrm{CO}_{2}$ storage" (storage); $(\triangle)$ " $\mathrm{CO}_{2}$ utilization" $\mathrm{OR}$ " $\mathrm{CO}_{2}$ conversion" $\mathrm{OR}$ " $\mathrm{CO}_{2}$ recycling" (reuse). The time spans above the graph indicate the years with more than 50 publications/year. The jump between 1990 and 1991 can be (partially) explained by a sudden increase in the number of publications in Web of Science per year, estimated by performing a search with neutral keyword "of" (inset).

increase in the number of carbon dioxide studies occurred between 1960 and 1990, followed by a first growth wave in the 1990 s and a second growth wave in the 2010s. The former may be ascribed to increasing interest in atmospheric $\mathrm{CO}_{2}$ levels and its effect on climate, while the latter corresponds with increasing interest in carbon dioxide capture, (geological) 


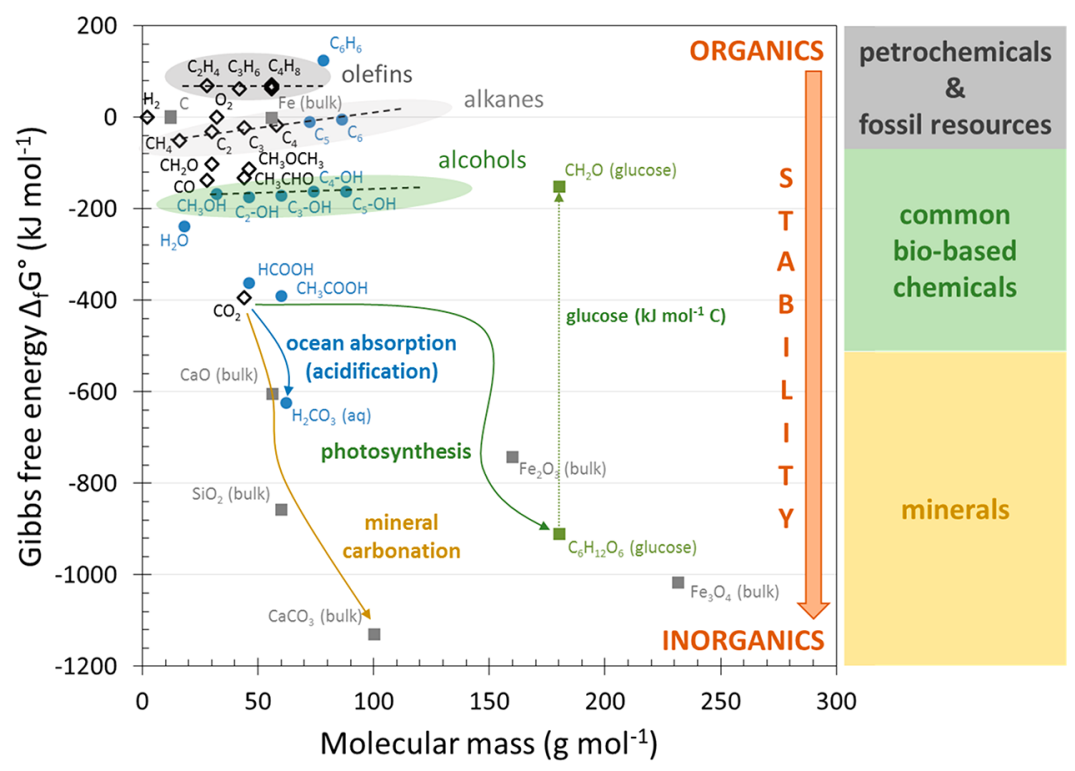

Figure 2. Overview of stability of selected chemical species. Gibbs free energy of formation as a function of molecular mass of different organic and inorganic species with indication of some homologous series (olefins, alkanes, and alcohols).

storage, and reuse (utilization, conversion, recycling). In what follows, some of the principles behind carbon dioxide capture, storage, and reuse will briefly be discussed.

\section{CARBON DIOXIDE CAPTURE, STORAGE, AND REUSE}

3.1. Carbon Dioxide capture. Natural processes of atmospheric carbon dioxide capture occur through equilibrium with the biosphere via photosynthesis, with the lithosphere through carbonation of minerals and with the hydrosphere through absorption. ${ }^{45}$ The former is the odd one out because, through the photosynthesis process, $\mathrm{CO}_{2}$ capture is accompanied by biochemical reduction of carbon dioxide with formation of biomass (e.g., trees, crops and algae), which can be reused as a resource of chemicals or energy. This biomass can also be converted into fossil resources with a significant energy input through high pressure and temperature, albeit on geological time scales. ${ }^{45}$ However, the carbonation of minerals in the lithosphere and the absorption of $\mathrm{CO}_{2}$ by the oceans are kinetically limited chemical processes, which result in chemicals with an even lower energy content than gaseous $\mathrm{CO}_{2}$ (Figure 2).

In order to mitigate $\mathrm{CO}_{2}$ emissions or control its atmospheric concentration directly, $\mathrm{CO}_{2}$ capture techniques are required. Different methods for $\mathrm{CO}_{2}$ capture exist, most of which can be classified into one of the following categories: (i) gas absorption, (ii) gas adsorption, (iii) cryogenic separation, (iv) membrane separation, and (v) mineral carbonation.

Absorption relies on the use of a solvent (e.g., amines, ${ }^{46,47}$ alkali solutions, ${ }^{48}$ or ionic liquids ${ }^{49,50}$ ) contacted with a $\mathrm{CO}_{2}$ containing gas stream in one vessel, resulting in a $\mathrm{CO}_{2}$ lean gas effluent and a $\mathrm{CO}_{2}$ laden solvent. This solvent is regenerated in a second vessel with the release of enriched $\mathrm{CO}_{2}$. Solvents should be resistant to degradation, nontoxic, and noncorrosive and should show low viscosity and fast reaction kinetics with $\mathrm{CO}_{2} \cdot{ }^{46,47}$ Besides these sometimes conflicting requirements, they should preferably also be cheap. While amine- and alkalibased $\mathrm{CO}_{2}$ absorption processes for gas purification have been industrially used for many decades, challenges associated with solvent degradation, volatility, and corrosion are yet to be addressed, especially for amine-based solvents. ${ }^{48}$ While alkali solutions are less corrosive by nature than amine solutions, corrosion remains an issue as the alkali solution absorbs flue gas contaminants and hence degrades. ${ }^{48}$ Besides a loss in absorption capacity due to precipitation of alkali salts (e.g., sulfates or nitrates), the kinetics of $\mathrm{CO}_{2}$ absorption are much slower for alkali solutions compared with amines. ${ }^{48}$ Ionic liquids, however, are favorable in terms of their low volatility, low flammability and thermal stability, though challenges remain due to the increased viscosity of ionic liquids with increasing $\mathrm{CO}_{2}$ absorption and their toxicity. ${ }^{51}$

Adsorption relies on preferential physisorption of $\mathrm{CO}_{2}$ over other compounds on a high-surface area adsorbent (e.g., zeolites $^{51-53}$ or metal-organic frameworks ${ }^{51-54}$ ). The adsorbent is regenerated by applying heat (temperature swing) and/ or decreasing pressure (pressure swing). Important properties of adsorbent materials include the $\mathrm{CO}_{2}$ adsorption selectivity, adsorption capacity, adsorption-desorption kinetics and resistance to poisoning and degradation. ${ }^{51}$ In this sense, the highly tailorable nature of metal-organic frameworks provides a major opportunity in terms of adsorbent properties optimization. ${ }^{53,54}$

Cryogenic separation relies on extensive cooling in order to separate $\mathrm{CO}_{2}$ from other compounds based on its boiling point. Because of the high cost of cooling, such a separation process should only be considered when the concentration of $\mathrm{CO}_{2}$ is already high (e.g., higher than $\left.50 \%\right){ }^{55}$ Additional challenges lie in the buildup of solid $\mathrm{CO}_{2}$ on the heatexchanger surface, which deteriorates the overall energy efficiency of the process. ${ }^{55}$

Membrane separation relies on the difference in permeation of different gases through a membrane (e.g., polymer membrane $^{56}$ or ceramic membrane $\left.{ }^{56}\right)$. The preferential permeation of either $\mathrm{CO}_{2}$ or the diluting gases allows us to obtain an enriched $\mathrm{CO}_{2}$ stream. Critical properties of the membrane include selectivity, permeability, and stability. ${ }^{56}$

Carbonation-decarbonation makes use of the chemical carbonation of solid minerals (typically alkali or earth alkali metal oxides). By decarbonation of the mineral carbonate at 


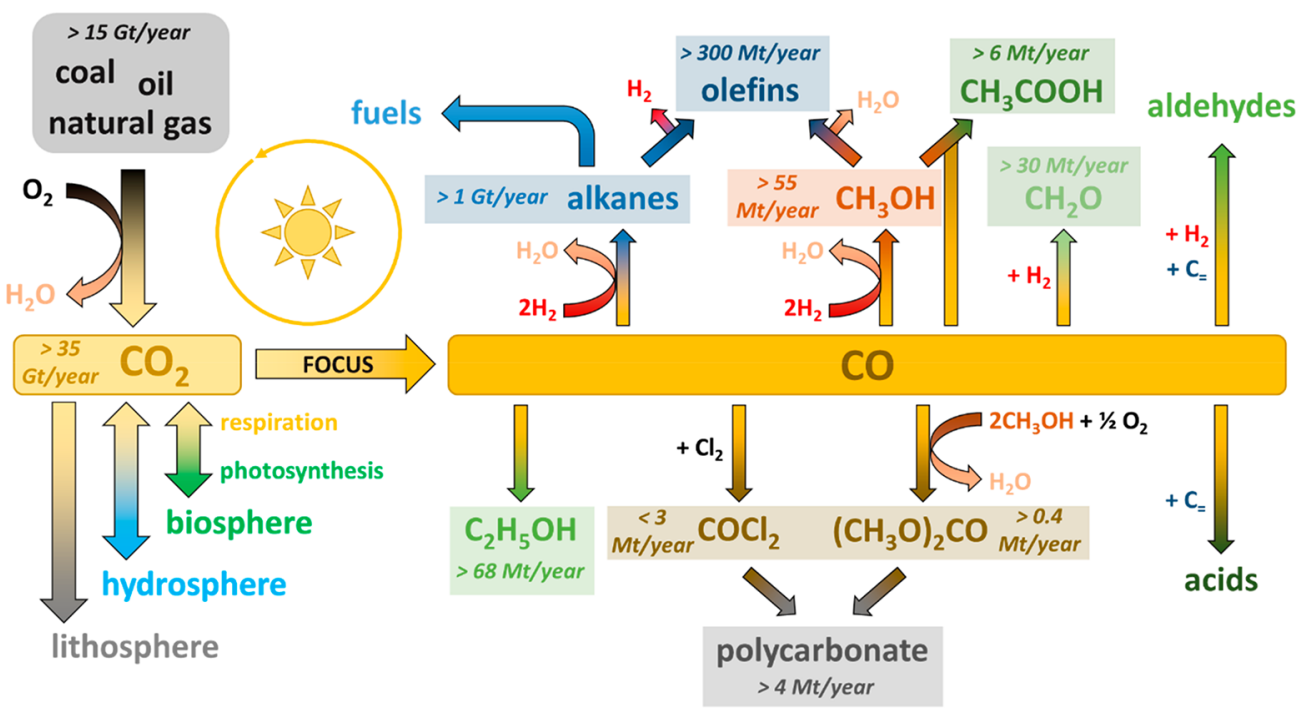

Figure 3. Selection of carbon dioxide production, storage, and conversion processes. In this scheme, the potential of carbon monoxide (CO) as an intermediate between carbon dioxide $\left(\mathrm{CO}_{2}\right)$ and a variety of chemicals is presented with an indication of annual global production volumes ${ }^{51,72-80}$ (in $\mathrm{Mt}$ year ${ }^{-1}$ or $\mathrm{Gt}$ year $^{-1}$ ). These production volumes are not necessarily realized by the indicated process. The scheme indicates that the combustion of fossil resources (coal, oil, and natural gas) results in $\mathrm{CO}_{2}$ emission, part of which is (i) very slowly captured in the lithosphere by formation of mineral carbonates, (ii) slowly captured in the hydrosphere by ocean absorption (acidification), and (iii) captured in the biosphere by means of photosynthesis. Double arrows toward the hydrosphere and biosphere indicate the possibility of $\mathrm{CO}_{2}$ emission by desorption from the oceans (in case the atmospheric $\mathrm{CO}_{2}$ concentration would decrease) and $\mathrm{CO}_{2}$ emission by respiration of organisms (via biomass combustion). In principle, $\mathrm{CO}_{2}$ can be converted into methane $\left(\mathrm{CH}_{4}\right)$, which is equivalent to natural gas. This work focuses on the conversion of $\mathrm{CO}_{2}$ through the intermediate $\mathrm{CO}$, a platform molecule from which ethanol $\left(\mathrm{C}_{2} \mathrm{H}_{5} \mathrm{OH}\right.$, by fermentation), polycarbonate (through phosgene, $\mathrm{COCl}{ }_{2}$, or dimethyl carbonate, $\left(\mathrm{CH}_{3} \mathrm{O}\right)_{2} \mathrm{CO}$ ), and acids (such as acetic acid, $\left.\mathrm{CH}_{3} \mathrm{COOH}\right)$ can be formed. Additionally, $\mathrm{CO}$ can be transformed into alkanes (FischerTropsch synthesis), methanol $\left(\mathrm{CH}_{3} \mathrm{OH}\right)$, formaldehyde $\left(\mathrm{CH}_{2} \mathrm{O}\right)$, and aldehydes when a source of (renewable) hydrogen $\left(\mathrm{H}_{2}\right)$ is available. Alkanes (catalytic dehydrogenation, catalytic cracking, or steam cracking) or $\mathrm{CH}_{3} \mathrm{OH}$ (methanol-to-olefins process) can further be transformed into olefins $\left(\mathrm{C}_{=}\right)$. Alternatively, alkanes can be further refined in order to yield hydrocarbon fuels (or other petrochemical building blocks), thereby allowing us to close the carbon loop.

elevated temperature or reduced pressure, a $\mathrm{CO}_{2}$ rich gas stream can be obtained. Important challenges with respect to such minerals are the mechanical and structural stability after prolonged carbonation-decarbonation cycling. Additionally, the effect of $\mathrm{SO}_{x}$ and $\mathrm{NO}_{x}$ should be borne in mind.

Besides a distinction between $\mathrm{CO}_{2}$ capture based on the separation technology, efforts in $\mathrm{CO}_{2}$ capture can be classified as direct or indirect $\mathrm{CO}_{2}$ capture depending on whether $\mathrm{CO}_{2}$ is caught from the air directly or from (industrial) exhaust gases.

3.2. Carbon Dioxide Storage. An early suggestion for $\mathrm{CO}_{2}$ capture and storage through geo-engineering came from Cesare Marchetti in 1977, who proposed to separate $\mathrm{CO}_{2}$ from flue gases with subsequent disposal either (i) in exhausted gas or oil fields and other geological cavities or (ii) by injection in sinking ocean currents in order to improve the kinetics of $\mathrm{CO}_{2}$ absorption. ${ }^{57}$ Ocean absorption, however, does not seem to be a favorable idea due to the resulting ocean acidification, which harms marine ecosystems. ${ }^{58}$ While several test projects have been started with respect to geological $\mathrm{CO}_{2}$ storage, uncertainty remains with respect to unfavorable long-term effects (e.g., seismic activity or leakage). ${ }^{51,58,59}$ The reader is referred elsewhere for a detailed overview. ${ }^{58,59}$

No doubt the most elegant carbon dioxide storage strategy would be biological storage by promoting reforestation. The development of efficient methods for urban agriculture could create opportunities for nature to reclaim rural agricultural areas. When the produced biomass is periodically harvested and consumed, biological carbon dioxide storage becomes a strategy for carbon dioxide reuse, the topic of next paragraph.
3.3. Carbon Dioxide Reuse. Carbon dioxide reuse can be divided into three categories: (i) carbon dioxide utilization comprises processes in which carbon dioxide is utilized but not necessarily converted; (ii) biological conversion includes biochemical carbon dioxide conversion into biomass through photosynthesis; (iii) carbon dioxide conversion is used for the deliberate industrial conversion of carbon dioxide into chemicals or fuels.

3.3.1. Carbon Dioxide Utilization. A first example of $\mathrm{CO}_{2}$ utilization is its use in enhanced oil recovery, typically a onetime use accompanied by $\mathrm{CO}_{2}$ storage, whereby $\mathrm{CO}_{2}$ is used to enhance the yield of fossil resource recovery by pumping $\mathrm{CO}_{2}$ into geological reservoirs which contain oil and/or gas. While one could argue that enhanced oil recovery results in $\mathrm{CO}_{2}$ storage, it also provides new fossil resources that are likely to cause significant $\mathrm{CO}_{2}$ emissions during their life cycle. A second example is the production of carbonated beverages, in which $\mathrm{CO}_{2}$ is stored as $\mathrm{H}_{2} \mathrm{CO}_{3}$. Carbon dioxide utilization in beverages is temporary as $\mathrm{CO}_{2}$ will again be released from the beverage when consumed. A third example is the use of supercritical $\mathrm{CO}_{2}$ as an extraction or reaction solvent. ${ }^{60-63}$ Because $\mathrm{CO}_{2}$ is nonflammable, nontoxic, and relatively inert, it is perceived as an interesting candidate solvent for green chemistry. ${ }^{60}$ Moreover, the supercritical regime of $\mathrm{CO}_{2}$ is readily accessible contrary to, e.g., that of water. ${ }^{60}$

All of the above-mentioned methods for carbon dioxide utilization have in common that they do not contribute to $\mathrm{CO}_{2}$ emission mitigation. In the following paragraphs, $\mathrm{CO}_{2}$ conversion methods are discussed that have the potential to 
contribute to $\mathrm{CO}_{2}$ emission mitigation and closure of the carbon loop.

3.3.2. Biological Conversion. Biological conversion of $\mathrm{CO}_{2}$ into biomass is typically realized by plants through the process of photosynthesis. Microalgae are considered among the fastest growing species of plants (e.g., compared with crops and trees), a property that makes them a promising candidate for biological $\mathrm{CO}_{2}$ capture and conversion. ${ }^{64}$ Nevertheless, economic feasibility currently hinders the use of algal biofuels and biochemicals. ${ }^{65}$ Product diversification in an algal biorefinery concept could provide future opportunities for the valorization of algae. ${ }^{65}$ The current situation for other biomass feedstocks is similar to that of algae, as high production costs associated with biomass processing ${ }^{66}$ impair their competitiveness with existing processes. Today, biological $\mathrm{CO}_{2}$ conversion and the subsequent use of produced biomass is mainly applied through agriculture for the food industry and the production of biofuels (bioethanol and biodiesel), forestry for the furniture and paper industry, and anaerobic digestion of organic waste for the production of biogas. During the following decades, biomass-based processes are expected to increasingly focus not only on food and energy production but also on the production of value-added chemicals. ${ }^{66-68}$

3.3.3. Carbon Dioxide Conversion. The direct conversion of carbon dioxide into useful chemicals includes the production of urea, salicylic acid, dimethyl carbonate, polyurethane, polycarbonate, polyacrylates, and (in)organic carbonates. ${ }^{45,69,70}$ Additional possibilities lie in its use as a mild oxidant, for example, in the oxidative dehydrogenation of alkanes with formation of alkenes, water, and carbon monoxide. ${ }^{69}$ Finally, carbon dioxide can also be hydrogenated into chemicals or fuels such as methane (methanation), formaldehyde, dimethyl ether, formic acid, methanol, and other alcohols. ${ }^{45,69,70}$ The efficient methanation of carbon dioxide using renewable hydrogen (e.g., from electrolysis using wind or solar electricity) and subsequent injection in the natural gas grid could be particularly interesting as a method of energy storage.

Alternatively, carbon dioxide can first be converted into carbon monoxide, a building block for a broad variety of chemicals and fuels. Figure 3 gives an overview of some carbon dioxide sources and sinks. The main carbon dioxide sources are the combustion of fossil fuels (such as coal, oil, and natural gas), the respiration of organisms through biomass combustion and desorption from the oceans (when the partial pressure of carbon dioxide in the atmosphere decreases). As previously mentioned, carbon dioxide can also be captured and stored in the lithosphere (mineral carbonates), hydrosphere (absorption by oceans), and biosphere (photosynthesis).

The main focus of this review lies on the direct conversion of carbon dioxide, for example, into carbon monoxide, a process deemed to have economic potential. ${ }^{71}$ Carbon monoxide can be converted into chemicals such as ethanol (e.g., through fermentation), polycarbonates (with phosgene or dimethyl carbonate as intermediate), and acids. By adding (renewable) hydrogen, the production of aldehydes, methanol, and alkanes (e.g., through Fischer-Tropsch synthesis) can be realized. Moreover, olefins can be produced from carbon monoxide via methanol (methanol-to-olefins process) or from alkanes (catalytic dehydrogenation, catalytic cracking or steam cracking) as intermediate. Figure 3 indicates the global annual production volume, not necessarily through the proposed process, in order to give an estimate of the capacity of chemicals or fuels as carbon sink. The figures show that, while the production of chemicals could provide a carbon sink for hundreds of $\mathrm{Mt}$ year $^{-1}$, production of fuels would be necessary in order to reach the Gt year ${ }^{-1}$ level and close the carbon loop.

The conversion of $\mathrm{CO}_{2}$ to $\mathrm{CO}$ can be realized by a (photo)electric current, by thermal reduction or by chemical reduction. Chemical reduction, which is the focus of this review, relies on the rearrangement of chemical bonds in a reducing agent such as $\mathrm{CH}_{4}$ or $\mathrm{H}_{2}$.

3.4. Pioneers in Industrial Carbon Dioxide Capture, Storage, and Reuse. Industrial (direct) air capture and the subsequent recycling of $\mathrm{CO}_{2}$ into chemicals/fuels is currently under development and already being demonstrated by pioneering companies such as Climeworks, Carbon Engineering, Global Thermostat, Carbon Recycling International, INERATEC $\mathrm{GmbH}$ and Nordic Blue Crude. Indeed, in recent years the number of start-up companies envisaging to close the carbon loop using renewable energy and $\mathrm{CO}_{2}$ as a feedstock has surged. Carbicrete, however, aims to reduce the carbon footprint of the construction sector by combining mineral waste and $\mathrm{CO}_{2}$ carbonation in a novel way of curing concrete without making use of cement. ${ }^{81-83}$

\section{CHEMICAL LOOPING}

4.1. Principle. Chemical looping processes can play an important role in $\mathrm{CO}_{2}$ conversion. They make use of stable solid intermediates in order to realize a redox reaction or gas separation. In what follows, three categories of chemical looping processes will be distinguished: (i) chemical looping redox reactions; (ii) thermochemical looping redox reactions; (iii) chemical looping carbon dioxide separation.

Chemical looping redox reactions generally make use of a metal oxide oxygen storage material (reduced form, $\mathrm{M}$; oxidized form, $\mathrm{MO}$, which transfers oxygen from the oxidant (e.g., $\mathrm{O}_{2}, \mathrm{H}_{2} \mathrm{O}$, or $\mathrm{CO}_{2}$ ) to the reductant (e.g., C, $\mathrm{CH}_{4}, \mathrm{H}_{2}$ ). Vice versa, electrons are transferred by the oxygen storage material from the reductant to the oxidant. Equations 1 and 2 illustrate the general concept of such redox reactions. The global reaction is an ordinary redox reaction (eq 3). Because the global reaction is split into two sub reactions, however, the reduced and oxidized product can be inherently separated by performing the two reactions at two different points in time or space.

$$
\begin{aligned}
& \text { oxidant }+\mathrm{M}_{(\mathrm{s})} \rightarrow \text { reduced product }+\mathrm{MO}_{(\mathrm{s})} \\
& \text { reductant }+\mathrm{MO}_{(\mathrm{s})} \rightarrow \text { oxidized product }+\mathrm{M}_{(\mathrm{s})} \\
& \text { oxidant }+ \text { reductant } \\
& \quad \rightarrow \text { reduced product }+ \text { oxidized product }
\end{aligned}
$$

Thermochemical looping redox reactions are similar to ordinary chemical looping redox reactions but differ in the method of metal oxide reduction. Here, the reduction of the metal oxide occurs thermally through oxygen evolution. The oxidation of the reduced metal oxide is analogous to the one in chemical looping redox reactions. These reactions as well as the global reaction are presented in eqs 4-6.

$$
\begin{aligned}
& \text { oxidant }+\mathrm{M}_{(\mathrm{s})} \rightarrow \text { reduced product }+\mathrm{MO}_{(\mathrm{s})} \\
& \mathrm{MO}_{(\mathrm{s})} \stackrel{\text { heat }}{\longrightarrow} \frac{1}{2} \mathrm{O}_{2(\mathrm{~g})}+\mathrm{M}_{(\mathrm{s})}
\end{aligned}
$$




$$
\text { oxidant } \stackrel{\text { heat }}{\longrightarrow} \text { reduced product }+\frac{1}{2} \mathrm{O}_{2(\mathrm{~g})}
$$

Chemical looping carbon dioxide separation makes use of an (earth) alkali metal oxide carbon dioxide sorbent (denoted $\mathrm{MO})$, which can capture and release carbon dioxide $\left(\mathrm{CO}_{2}\right)$. The process of $\mathrm{CO}_{2}$ capture is termed carbonation ( $\mathrm{MO}$ is transformed into $\mathrm{MCO}_{3}$ ), while the process of $\mathrm{CO}_{2}$ release is termed decarbonation or calcination $\left(\mathrm{MCO}_{3}\right.$ is transformed into MO). The carbonation (eq 7) and decarbonation (eq 8) reactions can be periodically applied in order to separate $\mathrm{CO}_{2}$ from diluted streams such as exhaust gases. The net process is the upgrading of a diluted $\mathrm{CO}_{2}$-containing stream to a $\mathrm{CO}_{2}$ rich stream.

$$
\begin{aligned}
& \mathrm{CO}_{2 \text { (diluted) }}+\mathrm{MO}_{(\mathrm{s})} \rightarrow \mathrm{MCO}_{3(\mathrm{~s})} \\
& \mathrm{MCO}_{3(\mathrm{~s})} \rightarrow \mathrm{CO}_{2(\text { rich })}+\mathrm{MO}_{(\mathrm{s})}
\end{aligned}
$$

In all three types of chemical looping processes, illustrated in Figure 4, the oxygen storage material and $\mathrm{CO}_{2}$ sorbent are assumed to be fully regenerated after each chemical looping cycle.

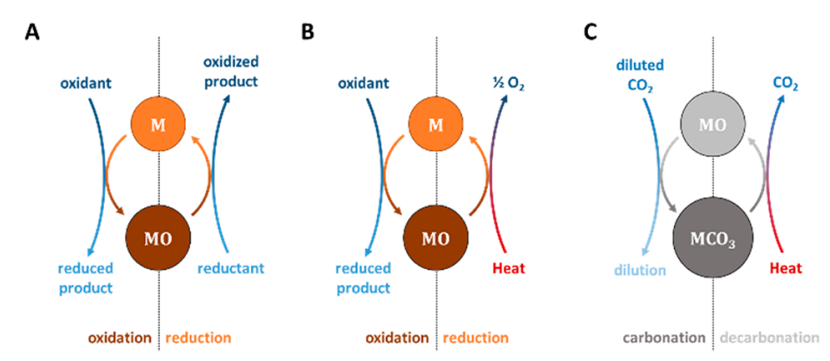

Figure 4. Schematic representation of chemical looping processes. (A) Chemical looping redox reactions. (B) Thermochemical looping redox reactions. (C) Chemical looping carbon dioxide separation. The reduction and decarbonation step in (B) and (C) can also be realized by decreasing the partial pressure of oxygen and carbon dioxide, for example, by means of an inert sweep gas.

4.2. Process Concepts. Different types of processes within the previously described chemical looping approaches can be distinguished. In what follows, a brief history of the development of chemical looping processes will be presented on the basis of a selection of historical contributions. This selection is far from exhaustive but is chosen so as to reflect the long history of research and development on chemical looping processes, the start of which may date back at least 150 years ago with the study of reversible oxygen transport occurring through hemoglobin crystals. ${ }^{84}$

4.2.1. (Thermo)chemical Looping Redox Reactions. The concept of chemical looping redox reactions can be traced back to the 19th century, when the brothers Quentin and Arthur Leon Brin successfully commercialized the production of oxygen with unprecedented purity by means of a (thermo)chemical looping process, patented since the 1880 s. $^{85,86} \mathrm{By}$ periodically contacting barium oxides to air and enriched oxygen in repeated temperature/pressure swings, the Brin brothers succeeded in enriching oxygen up to $95 \%$ purity with balance $\mathrm{N}_{2}{ }^{85}$ The corresponding reactions are presented below (eqs 9 and 10). In the 1890s, Franz Josef Bergmann proposed a similar use of manganese oxides for oxygen production albeit in view of calcium carbide production in blast furnaces. 87

$$
\begin{aligned}
& 2 \mathrm{BaO}_{2(\mathrm{~s})} \rightarrow \mathrm{O}_{2(\mathrm{~g})}+2 \mathrm{BaO}_{(\mathrm{s})} \\
& \mathrm{O}_{2(\mathrm{~g})}(\text { air })+2 \mathrm{BaO}_{(\mathrm{s})} \rightarrow 2 \mathrm{BaO}_{2(\mathrm{~s})}
\end{aligned}
$$

Another chemical looping redox process can be traced back to 1910, when Anton Messerschmitt patented a method for the production of high purity hydrogen using a process of cyclic iron oxide reduction and oxidation. ${ }^{88}$ Messerschmitt proposed to reduce a spongy iron oxide with a mixture of hydrocarbons and steam, the latter to suppress carbon formation, and to reoxidize this iron oxide with steam to produce hydrogen. ${ }^{88}$ The reactions upon which the so-called steam-iron process is based and its global reaction are presented in eqs 11-13. In the early 20th century, the separation between products was realized in batch; i.e., a reactor loaded with iron oxide was reduced to iron by a hydrocarbon fuel, after which the reactor was purged and steam was fed in order to reoxidize iron to iron oxide. This allowed to obtain hydrogen with a relatively high purity.

$$
\begin{aligned}
& \mathrm{C}_{m} \mathrm{H}_{2 n(\mathrm{~g})}+\frac{2 m+n}{4} \mathrm{Fe}_{3} \mathrm{O}_{4(\mathrm{~s})} \\
& \rightarrow m \mathrm{CO}_{2(\mathrm{~g})}+n \mathrm{H}_{2} \mathrm{O}_{(\mathrm{g})}+\frac{6 m+3 n}{4} \mathrm{Fe}_{(\mathrm{s})} \\
& (2 m+n) \mathrm{H}_{2} \mathrm{O}_{(\mathrm{g})}+\frac{6 m+3 n}{4} \mathrm{Fe}_{(\mathrm{s})} \\
& \rightarrow(2 m+n) \mathrm{H}_{2(\mathrm{~g})}+\frac{2 m+n}{4} \mathrm{Fe}_{3} \mathrm{O}_{4(\mathrm{~s})} \\
& \mathrm{C}_{m} \mathrm{H}_{2 n(\mathrm{~g})}+2 m \mathrm{H}_{2} \mathrm{O}_{(\mathrm{g})} \rightarrow m \mathrm{CO}_{2(\mathrm{~g})}+(2 m+n) \mathrm{H}_{2(\mathrm{~g})}
\end{aligned}
$$

In the 1950s, several chemical looping processes for the production of compounds other than hydrogen were developed. In 1952, Dickinson patented a method to produce carbon monoxide from solid carbonaceous materials (e.g., coal) via chemical looping, using air and/or steam in the oxidation step with production of heat and/or hydrogen. ${ }^{89}$ In 1953, Jones patented a process for syngas production from carbonaceous materials with tunable hydrogen content by a combination with the steam-iron process. ${ }^{90}$ In 1954, Lewis and Gilliland patented a chemical looping process for the production of pure $\mathrm{CO}_{2}$ from carbonaceous fuels and air by using what they called a copper oxide solid oxygen carrier. ${ }^{91}$ The proposed reactions are presented in eqs 14-16. In fact, although their focus was primarily on producing $\mathrm{CO}_{2}$, the process that Lewis and Gilliland proposed is now referred to as chemical looping combustion.

$$
\begin{aligned}
& \mathrm{C}_{m} \mathrm{H}_{2 n(\mathrm{~g})}+(2 m+n) \mathrm{CuO}_{(\mathrm{s})} \\
& \rightarrow m \mathrm{CO}_{2(\mathrm{~g})}+n \mathrm{H}_{2} \mathrm{O}_{(\mathrm{g})}+(2 m+n) \mathrm{Cu}_{(\mathrm{s})} \\
& \frac{2 m+n}{2} \mathrm{O}_{2(\mathrm{~g})}+(2 m+n) \mathrm{Cu}_{(\mathrm{s})} \\
& \rightarrow(2 m+n) \mathrm{CuO}_{(\mathrm{s})}+\text { heat } \\
& \mathrm{C}_{m} \mathrm{H}_{2 n(\mathrm{~g})}+\frac{2 m+n}{2} \mathrm{O}_{2(\mathrm{~g})} \rightarrow m \mathrm{CO}_{2(\mathrm{~g})}+n \mathrm{H}_{2} \mathrm{O}_{(\mathrm{g})}
\end{aligned}
$$

The concept of thermally splitting water in hydrogen and oxygen by means of a two-step chemical looping process can be traced back at least to 1966, when Funk and Reinstrom made a thermodynamic study on the decomposition of water 
for hydrogen production. ${ }^{92}$ After a patent filed by Schulten and Knoche in $1972,{ }^{93}$ research interest in other sulfur-based thermochemical looping cycles for hydrogen production increased in the 1970s. ${ }^{94,95}$ In 1976, Kameyama and coworkers published a particularly thorough screening method for potential multistep thermochemical hydrogen production cycles based on metal chlorides, bromides, iodides, sulfates and nitrates. $^{96}$ The three-step cycle proposed by Schulten and Knoche, which requires recycling of gaseous $\mathrm{SO}_{2}$, is presented by eqs $17-19$. The global reaction corresponds with eq 20 .

$$
\begin{aligned}
& \mathrm{SO}_{2(\mathrm{~g})}+\mathrm{Fe}_{2} \mathrm{O}_{3(\mathrm{~s})} \rightarrow \mathrm{FeO}_{(\mathrm{s})}+\mathrm{FeSO}_{4(\mathrm{~s})} \\
& \frac{1}{3} \mathrm{H}_{2} \mathrm{O}_{(\mathrm{g})}+\mathrm{FeO}_{(\mathrm{s})} \rightarrow \frac{1}{3} \mathrm{H}_{2(\mathrm{~g})}+\frac{1}{3} \mathrm{Fe}_{3} \mathrm{O}_{4(\mathrm{~s})} \\
& \frac{1}{3} \mathrm{Fe}_{3} \mathrm{O}_{4(\mathrm{~s})}+\mathrm{FeSO}_{4(\mathrm{~s})} \rightarrow \mathrm{Fe}_{2} \mathrm{O}_{3(\mathrm{~s})}+\frac{1}{6} \mathrm{O}_{2(\mathrm{~g})}+\mathrm{SO}_{2(\mathrm{~g})} \\
& \frac{1}{3} \mathrm{H}_{2} \mathrm{O}_{(\mathrm{g})} \rightarrow \frac{1}{3} \mathrm{H}_{2(\mathrm{~g})}+\frac{1}{6} \mathrm{O}_{2(\mathrm{~g})}
\end{aligned}
$$

With their 1983 publication, Richter and Knoche gave a new perspective to chemical looping processes, in particular with respect to the combustion of hydrocarbons for power production. ${ }^{97}$ They showed that the theoretical efficiency of chemical looping combustion is higher than that of traditional combustion because of the reversibility of metal oxide redox processes, which results in a decreased entropy production. ${ }^{97}$ Four years later, in 1987, this idea was picked up by Ishida and co-workers who first introduced the term chemical-looping combustion. ${ }^{98}$ Further work by Ishida and Jin was performed in the 1990s and a patent was granted in $1995 .^{99-102}$ In their 1994 publication, by combining the ideas of Lewis and Gilliland $^{91}$ and those of Richter and Knoche, ${ }^{97}$ Ishida and Jin first highlighted the potential of chemical looping combustion as an efficient energy production process with inherent separation of $\mathrm{CO}_{2}$, which could subsequently be stored or utilized-and combustion air. ${ }^{99,100}$

It should be noted that many other researchers studied chemical looping processes in the late 1990s, albeit without mentioning chemical looping in their publications. One such example is the work by Van Looij in 1994, who (re)invented syngas production from methane, steam, and air with a chemical looping approach. ${ }^{103,104}$ In this process, while a chemical looping combustor was used for heat generation, a catalytic re-former was still necessary for the syngas production. In 2001, Mattisson and Lyngfelt proposed to use chemical looping re-forming for the coproduction of power and $\mathrm{H}_{2}$ with inherent $\mathrm{CO}_{2}$ separation. ${ }^{105-107}$ In order to reach high $\mathrm{H}_{2}$ yields, however, a water-gas shift reactor would also be required. The corresponding reactions are presented in eqs $21-23$.

$$
\begin{aligned}
& \mathrm{CH}_{4(\mathrm{~g})}+(2-z) \mathrm{M}_{y} \mathrm{O}_{x(\mathrm{~s})}+z \mathrm{H}_{2} \mathrm{O} \\
& \quad \rightarrow \mathrm{CO}_{2(\mathrm{~g})}+(2+z) \mathrm{H}_{2(\mathrm{~g})}+(2-z) \mathrm{M}_{y} \mathrm{O}_{x-1(\mathrm{~s})} \\
& \mathrm{O}_{2(\mathrm{~g})}+(2-z) \mathrm{M}_{y} \mathrm{O}_{x-1(\mathrm{~s})} \rightarrow(2-z) \mathrm{M}_{y} \mathrm{O}_{x(\mathrm{~s})}+\text { heat } \\
& \mathrm{CH}_{4(\mathrm{~g})}+\mathrm{O}_{2(\mathrm{~g})}+z \mathrm{H}_{2} \mathrm{O} \\
& \quad \rightarrow \mathrm{CO}_{2(\mathrm{~g})}+(2+z) \mathrm{H}_{2(\mathrm{~g})}+\text { heat }
\end{aligned}
$$

In 2006, Hong and co-workers suggested to make use of solar heat for the endothermic oxygen storage material reduction step in order to further increase the process efficiency of chemical looping combustion. ${ }^{108}$ Related to their chemical looping re-forming process, Rydén, Lyngfelt, and Mattisson proposed chemical looping for syngas production (eqs 24-26) in the same year. ${ }^{109}$ Since 2001, many researchers have proposed and studied similar chemical looping re-forming processes for the production of hydrogen or syngas. ${ }^{107,110-114}$

$$
\begin{aligned}
& \mathrm{C}_{m} \mathrm{H}_{2 n(\mathrm{~g})}+m \mathrm{M}_{y} \mathrm{O}_{x(\mathrm{~s})} \rightarrow m \mathrm{CO}_{(\mathrm{g})}+n \mathrm{H}_{2(\mathrm{~g})}+\mathrm{mM}_{y} \mathrm{O}_{x-1(\mathrm{~s}} \\
& \frac{m}{2} \mathrm{O}_{2(\mathrm{~g})}+m \mathrm{M}_{y} \mathrm{O}_{x-1(\mathrm{~s})} \rightarrow m \mathrm{M}_{y} \mathrm{O}_{x(\mathrm{~s})} \\
& \mathrm{C}_{m} \mathrm{H}_{2 n(\mathrm{~g})}+\frac{m}{2} \mathrm{O}_{2(\mathrm{~g})} \rightarrow m \mathrm{CO}_{(\mathrm{g})}+n \mathrm{H}_{2(\mathrm{~g})}
\end{aligned}
$$

The concept of chemical looping oxygen uncoupling was proposed by Mattisson and co-workers in 2009. ${ }^{115,116}$ This concept, illustrated by eqs 27-29, may be considered a combination of chemical looping and thermochemical looping processes. Reactions 27 and 28 occur in the first step, while reaction 29 completes the chemical loop in the second step. Note that eq 28 is also the global reaction, since reactions 27 and 29 cancel out. The main advantage of such a chemical looping approach lies in the strong enhancement of reaction rates. $^{15,116}$

$$
\begin{aligned}
& (2 m+n) \mathrm{M}_{y} \mathrm{O}_{x(\mathrm{~s})} \rightarrow \frac{2 m+n}{2} \mathrm{O}_{2(\mathrm{~g})}+(2 m+n) \mathrm{M}_{y} \mathrm{O}_{x-1(\mathrm{~s})} \\
& \mathrm{C}_{m} \mathrm{H}_{2 n(\mathrm{~g})}+\frac{2 m+n}{2} \mathrm{O}_{2(\mathrm{~g})} \rightarrow m \mathrm{CO}_{2(\mathrm{~g})}+n \mathrm{H}_{2} \mathrm{O}_{(\mathrm{g})} \\
& \frac{2 m+n}{2} \mathrm{O}_{2(\mathrm{~g})}+(2 m+n) \mathrm{M}_{y} \mathrm{O}_{x-1(\mathrm{~s})} \rightarrow(2 m+n) \mathrm{M}_{y} \mathrm{O}_{x(\mathrm{~s})}
\end{aligned}
$$

In 2010, Najera and co-workers proposed chemical looping dry re-forming (eqs 30-32) for the conversion of $\mathrm{CH}_{4}$ and $\mathrm{CO}_{2}$ into $\mathrm{CO}$. $^{117-120}$

$$
\begin{aligned}
& \mathrm{CH}_{4(\mathrm{~g})}+4 \mathrm{M}_{y} \mathrm{O}_{x(\mathrm{~s})} \rightarrow \mathrm{CO}_{2(\mathrm{~g})}+2 \mathrm{H}_{2} \mathrm{O}_{(\mathrm{g})}+4 \mathrm{M}_{y} \mathrm{O}_{x-1(\mathrm{~s})} \\
& 4 \mathrm{CO}_{2(\mathrm{~g})}+4 \mathrm{M}_{y} \mathrm{O}_{x-1(\mathrm{~s})} \rightarrow 4 \mathrm{CO}_{(\mathrm{g})}+4 \mathrm{M}_{y} \mathrm{O}_{x(\mathrm{~s})} \\
& \mathrm{CH}_{4(\mathrm{~g})}+3 \mathrm{CO}_{2(\mathrm{~g})} \rightarrow 4 \mathrm{CO}_{(\mathrm{g})}+2 \mathrm{H}_{2} \mathrm{O}_{(\mathrm{g})}
\end{aligned}
$$

In 2011, catalyst-assisted chemical looping was first proposed by Galvita and co-workers as a method to improve the achieved reduction degree of oxygen storage materials. ${ }^{114,121}$ The concept of autothermal chemical looping was elaborated on by $\mathrm{Hu}$ and co-workers in 2016. ${ }^{122}$ In this method, the endothermic methane re-forming and oxygen storage material reduction is compensated by cofeeding oxygen, resulting in exothermic combustion of part of the methane feed (eqs 33-35).

$$
\begin{aligned}
& \mathrm{CH}_{4(\mathrm{~g})}+(4-x) \mathrm{M}_{y} \mathrm{O}_{x(\mathrm{~s})}+\frac{x}{2} \mathrm{O}_{2(\mathrm{~g})} \\
& \rightarrow \mathrm{CO}_{2(\mathrm{~g})}+2 \mathrm{H}_{2} \mathrm{O}_{(\mathrm{g})}+(4-x) \mathrm{M}_{y} \mathrm{O}_{x-1(\mathrm{~s})}
\end{aligned}
$$




$$
\begin{aligned}
& (4-x) \mathrm{CO}_{2(\mathrm{~g})}+(4-x) \mathrm{M}_{y} \mathrm{O}_{x-1(\mathrm{~s})} \\
& \quad \rightarrow(4-x) \mathrm{CO}_{(\mathrm{g})}+(4-x) \mathrm{M}_{y} \mathrm{O}_{x(\mathrm{~s})} \\
& \mathrm{CH}_{4(\mathrm{~g})}+(3-x) \mathrm{CO}_{2(\mathrm{~g})}+\frac{x}{2} \mathrm{O}_{2(\mathrm{~g})} \\
& \quad \rightarrow(4-x) \mathrm{CO}_{(\mathrm{g})}+2 \mathrm{H}_{2} \mathrm{O}_{(\mathrm{g})}
\end{aligned}
$$

A schematic overview of catalyst-assisted chemical looping (autothermal) dry re-forming is presented in Figure 5. Besides

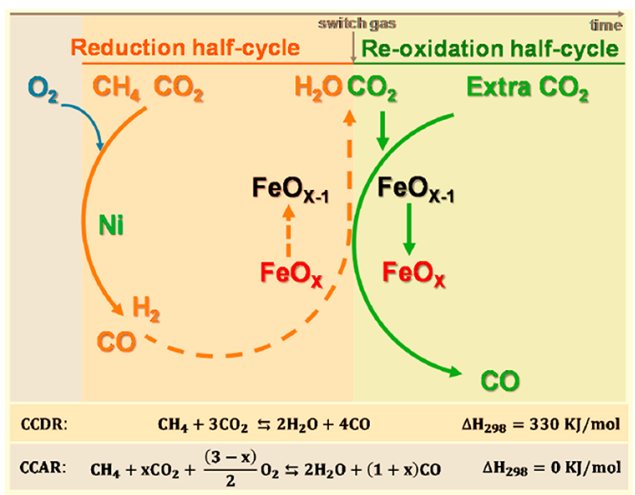

Figure 5. Schematic representation of catalyst-assisted chemical looping processes. $\mathrm{Ni}$ represents the $\mathrm{Ni}$ catalyst while $\mathrm{FeO}_{X}$ and $\mathrm{FeO}_{X-1}$ correspond with the oxidized and reduced state of the oxygen storage material. The global reaction of the corresponding processes are provided. CCDR: catalyst-assisted chemical looping dry reforming. CCAR: catalyst-assisted chemical looping autothermal dry re-forming. Reprinted with permission from ref 124. Copyright 2018 MDPI.

using methane as a reductant, Dharanipragada and co-workers demonstrated that catalyst-assisted chemical looping can also be realized using an alcohol such as methanol or ethanol as a reductant. $^{123}$

For a more elaborate overview of some of these chemical looping process concepts, the reader is referred to several comprehensive reviews. ${ }^{125-137}$ Additional historical context to the concept of chemical looping processes is provided in Supporting Information (Historical Context 2).

4.2.2. Chemical Looping Carbon Dioxide Separation. Although the true purpose at the time was not necessarily the separation of carbon dioxide, the application of earth alkali metal oxides for carbon dioxide removal can be traced back to 1931 with a patent by Gluud and co-workers. ${ }^{138}$ In this patent, they propose the application of such metal oxides for pushing the equilibrium water-gas shift reaction to the product side, thereby enhancing hydrogen production, and their periodic regeneration by means of calcination in the presence of air or steam. ${ }^{138}$ The corresponding reactions are presented in eqs 36-38.

$$
\begin{aligned}
& \mathrm{CO}_{(\mathrm{g})}+\mathrm{H}_{2} \mathrm{O}_{(\mathrm{g})} \rightarrow \mathrm{CO}_{2(\mathrm{~g})}+\mathrm{H}_{2(\mathrm{~g})} \\
& \mathrm{CO}_{2(\mathrm{~g})}+\mathrm{MO}_{(\mathrm{s})} \rightarrow \mathrm{MCO}_{3(\mathrm{~s})} \\
& \mathrm{MCO}_{3(\mathrm{~s})} \rightarrow \mathrm{CO}_{2(\mathrm{~g})}+\mathrm{MO}_{(\mathrm{s})}
\end{aligned}
$$

Interest in the use of a so-called $\mathrm{CO}_{2}$ acceptor during hydrocarbon processing was revived in the 1980 s. ${ }^{139,140}$ In the mid-1990s, Harrison and co-workers were perhaps the first to point out the benefits of such a process, not only in view of hydrogen production but also in terms of $\mathrm{CO}_{2}$ capture and disposal. ${ }^{141-143}$ In 1998, Nakagawa and Ohashi proposed the use of lithium metazirconate as a high-temperature $\mathrm{CO}_{2}$ sorbent in hydrogen production and combustion plants for power production with $\mathrm{CO}_{2}$ capture. ${ }^{144}$ Such a configuration would make use of reactions $36-38$.

$$
\mathrm{H}_{2(\mathrm{~g})}+\frac{1}{2} \mathrm{O}_{2(\mathrm{~g})} \rightarrow \mathrm{H}_{2} \mathrm{O}_{(\mathrm{g})}+\text { heat }
$$

The application of calcium oxide for the continuous removal of $\mathrm{CO}_{2}$ from postcombustion exhaust gases was proposed in 1999 by Shimizu and co-workers. ${ }^{145}$

4.2.3. Combined Chemical Looping Processes. As early as 1996, Lyon patented a hydrogen production process, termed unmixed combustion or unmixed re-forming, in which chemical looping combustion and chemical looping carbon dioxide capture were combined in a three-step process. ${ }^{146-148}$ During the first step of the process, the nickel oxide catalyst is reduced (eq 40, endothermic) to a metallic nickel steam re-forming catalyst.

$$
\mathrm{CH}_{4(\mathrm{~g})}+4 \mathrm{NiO}_{(\mathrm{s})} \rightarrow \mathrm{CO}_{2(\mathrm{~g})}+2 \mathrm{H}_{2} \mathrm{O}_{(\mathrm{g})}+4 \mathrm{Ni}_{(\mathrm{s})}
$$

This catalyst catalyzes the steam re-forming of methane (eq 41, endothermic) in the second step. The water-gas shift reaction equilibrium (eq 42, exothermic) is shifted to the product side by carbonation of a $\mathrm{CO}_{2}$ sorbent material (eq 43, exothermic). The overall reaction in the second step is an intensified production of hydrogen by methane re-forming with a combination of endo- and exothermic reactions (eq 44).

$$
\begin{aligned}
& \mathrm{CH}_{4(\mathrm{~g})}+\mathrm{H}_{2} \mathrm{O}_{(\mathrm{g})} \stackrel{\mathrm{Ni}}{\rightarrow} \mathrm{CO}_{(\mathrm{g})}+3 \mathrm{H}_{2(\mathrm{~g})} \\
& \mathrm{CO}_{(\mathrm{g})}+\mathrm{H}_{2} \mathrm{O}_{(\mathrm{g})} \rightarrow \mathrm{CO}_{2(\mathrm{~g})}+\mathrm{H}_{2(\mathrm{~g})} \\
& \mathrm{CO}_{2(\mathrm{~g})}+\mathrm{MO}_{(\mathrm{s})} \rightarrow \mathrm{MCO}_{3(\mathrm{~s})} \\
& \mathrm{CH}_{4(\mathrm{~g})}+2 \mathrm{H}_{2} \mathrm{O}_{(\mathrm{g})}+\mathrm{MO}_{(\mathrm{s})} \rightarrow 4 \mathrm{H}_{2(\mathrm{~g})}+\mathrm{MCO}_{3(\mathrm{~s})}
\end{aligned}
$$

In the third step, the solids are regenerated in air by once more combining exo- and endothermic processes of nickel oxidation (eq 45, exothermic) and metal carbonate decomposition (eq 46 , endothermic) in air. The overall reaction for this step is given in eq 47 . One drawback of this process is that the resulting $\mathrm{CO}_{2}$ is diluted with (oxygen-depleted) air.

$$
\begin{aligned}
& 4 \mathrm{Ni}_{(\mathrm{s})}+2 \mathrm{O}_{2(\mathrm{~g})} \rightarrow 4 \mathrm{NiO}_{(\mathrm{s})} \\
& \mathrm{MCO}_{3(\mathrm{~s})} \rightarrow \mathrm{MO}_{(\mathrm{s})}+\mathrm{CO}_{2(\mathrm{~g})} \\
& 4 \mathrm{Ni}_{(\mathrm{s})}+2 \mathrm{O}_{2(\mathrm{~g})}+\mathrm{MCO}_{3(\mathrm{~s})} \rightarrow 4 \mathrm{NiO}_{(\mathrm{s})}+\mathrm{MO}_{(\mathrm{s})}+\mathrm{CO}_{2(\mathrm{~g})}
\end{aligned}
$$

The overall reaction then corresponds with eq 48. In summary, this process combines chemical looping combustion (eqs 40 and 45) with steam re-forming (eq 41), water-gas shift reaction (eq 42), and chemical looping carbon dioxide capture (eqs 43 and 46).

$$
2 \mathrm{CH}_{4(\mathrm{~g})}+2 \mathrm{O}_{2(\mathrm{~g})} \rightarrow 4 \mathrm{H}_{2(\mathrm{~g})}+2 \mathrm{CO}_{2(\mathrm{~g})}
$$

Following this patent, much effort has been put into studying this process-later termed sorption enhanced chemical looping re-forming-experimentally. ${ }^{149-156}$ In 2010, Abanades and coworkers proposed a variant of this process (Figure 6) to overcome the drawback of $\mathrm{CO}_{2}$ dilution. ${ }^{157}$ As a first step, they propose sorption enhanced steam re-forming using a 


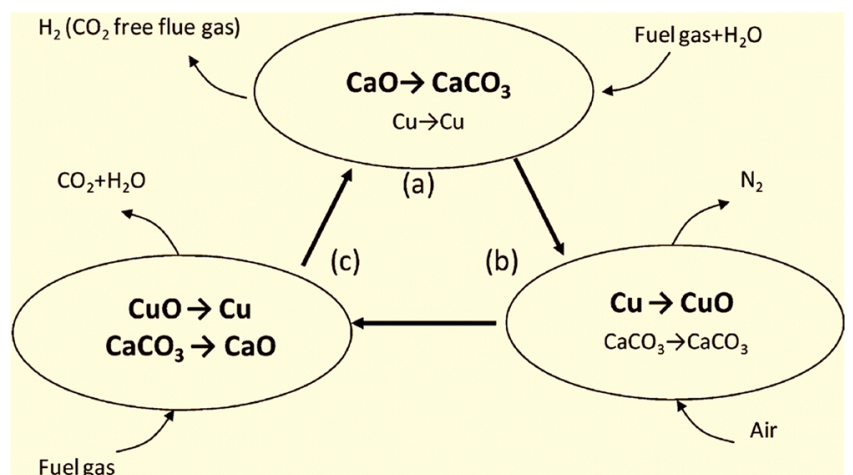

Figure 6. Schematic representation of the combined chemical looping process proposed by Abanades and co-workers. This chemical looping process for hydrogen production is based on sorption-enhanced steam re-forming of methane. Reprinted with permission from ref 157. Copyright 2010 American Chemical Society.

(promoted) copper catalyst (eqs 41-44). The second step is the oxidation of copper under conditions where the metal carbonate does not decompose. Finally, the metal carbonate is decomposed (endothermic process), while copper oxide is reduced, e.g., using syngas with high $\mathrm{CO}$ content (exothermic process).

In 2015, Galvita and co-workers proposed a two-step combined chemical looping approach for energy storage. ${ }^{158}$ In the first step, methane is oxidized over a metal oxide oxygen storage material, re-forming catalyst and $\mathrm{CO}_{2}$ sorbent. During this "chemical charging" step, the oxygen storage material is reduced (eq 49), carbon is deposited (eq 50), and the $\mathrm{CO}_{2}$ sorbent is carbonated (eq 51). The overall reaction during the first step is represented in eq 52.

$$
\begin{aligned}
& \mathrm{CH}_{4(\mathrm{~g})}+\mathrm{Fe}_{3} \mathrm{O}_{4(\mathrm{~s})} \rightarrow \mathrm{CO}_{2(\mathrm{~g})}+2 \mathrm{H}_{2} \mathrm{O}_{(\mathrm{g})}+3 \mathrm{Fe}_{(\mathrm{s})} \\
& \mathrm{CH}_{4(\mathrm{~g})} \rightarrow \mathrm{C}_{(\mathrm{s})}+2 \mathrm{H}_{2(\mathrm{~g})} \\
& 5 \mathrm{CO}_{2(\mathrm{~g})}+5 \mathrm{CaO}_{(\mathrm{s})} \rightarrow 5 \mathrm{CaCO}_{3(\mathrm{~s})} \\
& 2 \mathrm{CH}_{4(\mathrm{~g})}+4 \mathrm{CO}_{2(\mathrm{~g})}+\mathrm{Fe}_{3} \mathrm{O}_{4(\mathrm{~s})}+5 \mathrm{CaO}_{(\mathrm{s})} \\
& \quad \rightarrow \mathrm{C}_{(\mathrm{s})}+2 \mathrm{H}_{2} \mathrm{O}_{(\mathrm{g})}+2 \mathrm{H}_{2(\mathrm{~g})}+3 \mathrm{Fe}_{(\mathrm{s})}+5 \mathrm{CaCO}_{3(\mathrm{~s})}
\end{aligned}
$$

During the second step, "chemical discharging", the solids are regenerated. The metal carbonate is decomposed (eq 53) and the released $\mathrm{CO}_{2}$ oxidizes the reduced oxygen storage material (eq 54) as well as the deposited carbon (eq 55) with production of $\mathrm{CO}$. The overall reaction during this second step is represented in eq 56 .

$$
\begin{aligned}
& 5 \mathrm{CaCO}_{3(\mathrm{~s})} \rightarrow 5 \mathrm{CaO}_{(\mathrm{s})}+5 \mathrm{CO}_{2(\mathrm{~g})} \\
& 4 \mathrm{CO}_{2(\mathrm{~g})}+3 \mathrm{Fe}_{(\mathrm{s})} \rightarrow \mathrm{Fe}_{3} \mathrm{O}_{4(\mathrm{~s})}+4 \mathrm{CO}_{(\mathrm{g})} \\
& \mathrm{CO}_{2(\mathrm{~g})}+\mathrm{C}_{(\mathrm{s})} \rightarrow 2 \mathrm{CO}_{(\mathrm{g})} \\
& 5 \mathrm{CaCO}_{3(\mathrm{~s})}+3 \mathrm{Fe}_{(\mathrm{s})}+\mathrm{C}_{(\mathrm{s})} \\
& \quad \rightarrow 5 \mathrm{CaO}_{(\mathrm{s})}+\mathrm{Fe}_{3} \mathrm{O}_{4(\mathrm{~s})}+6 \mathrm{CO}_{(\mathrm{g})}
\end{aligned}
$$

The global reaction of this combined chemical looping process is presented in eq 57 .

$$
2 \mathrm{CH}_{4(\mathrm{~g})}+4 \mathrm{CO}_{2(\mathrm{~g})} \rightarrow 2 \mathrm{H}_{2} \mathrm{O}_{(\mathrm{g})}+2 \mathrm{H}_{2(\mathrm{~g})}+6 \mathrm{CO}_{(\mathrm{g})}
$$

A schematic representation of the charge and discharge step of this combined chemical looping approach is shown in Figure 7.

More recently, the so-called superdry re-forming of methane has been proposed as a process to enhance the $\mathrm{CO}$ yield from the regular $\mathrm{CH}_{4}$ dry re-forming process. ${ }^{159}$ In the $\mathrm{CH}_{4}$ oxidation step, syngas is formed by dry re-forming over a nickel-based catalyst (eq 58). This mixture of $\mathrm{CO}$ and $\mathrm{H}_{2}$ then reduces the iron-based oxygen carrier (eqs 59 and 60), a process enhanced by the presence of a $\mathrm{CO}_{2}$ sorbent via Le Chatelier's principle. This step, which generally comprises reaction eqs 58-61, results in a reactor bed containing $\mathrm{Fe}$ and $\mathrm{CaCO}_{3}$ at the end of the $\mathrm{CH}_{4}$ oxidation step.

$$
\begin{aligned}
& \mathrm{CH}_{4(\mathrm{~g})}+\mathrm{CO}_{2(\mathrm{~g})} \rightarrow 2 \mathrm{H}_{2(\mathrm{~g})}+2 \mathrm{CO}_{(\mathrm{g})} \\
& \mathrm{H}_{2(\mathrm{~g})}+\frac{1}{4} \mathrm{Fe}_{3} \mathrm{O}_{4(\mathrm{~s})} \rightarrow \mathrm{H}_{2} \mathrm{O}_{(\mathrm{g})}+\frac{3}{4} \mathrm{Fe}_{(\mathrm{s})} \\
& \mathrm{CO}_{(\mathrm{g})}+\frac{1}{4} \mathrm{Fe}_{3} \mathrm{O}_{4(\mathrm{~s})} \rightarrow \mathrm{CO}_{2(\mathrm{~g})}+\frac{3}{4} \mathrm{Fe}_{(\mathrm{s})} \\
& \mathrm{CO}_{2(\mathrm{~g})}+\mathrm{CaO}_{(\mathrm{s})} \rightarrow \mathrm{CaCO}_{3(\mathrm{~s})}
\end{aligned}
$$

In the $\mathrm{CO}_{2}$ reduction step, isothermally initiated by an inert sweep gas, $\mathrm{CO}$ is formed upon release of $\mathrm{CO}_{2}$ from $\mathrm{CaCO}_{3}$ (eq 62), which subsequently oxidizes iron with formation of iron oxide and $\mathrm{CO}$ (eq 63). As with the $\mathrm{CH}_{4}$ oxidation step, the $\mathrm{CO}_{2}$ reduction step is enhanced by Le Chatelier's principle.

$$
\begin{aligned}
& \mathrm{CaCO}_{3(\mathrm{~s})} \rightarrow \mathrm{CO}_{2(\mathrm{~g})}+\mathrm{CaO}_{(\mathrm{s})} \\
& \mathrm{CO}_{2(\mathrm{~g})}+\frac{3}{4} \mathrm{Fe}_{(\mathrm{s})} \rightarrow \mathrm{CO}_{(\mathrm{g})}+\frac{1}{4} \mathrm{Fe}_{3} \mathrm{O}_{4(\mathrm{~s})}
\end{aligned}
$$

The global reaction of this combined chemical looping process is presented in eq 64 .

$$
\mathrm{CH}_{4(\mathrm{~g})}+3 \mathrm{CO}_{2(\mathrm{~g})} \rightarrow 4 \mathrm{CO}_{(\mathrm{g})}+2 \mathrm{H}_{2} \mathrm{O}_{(\mathrm{g})}
$$
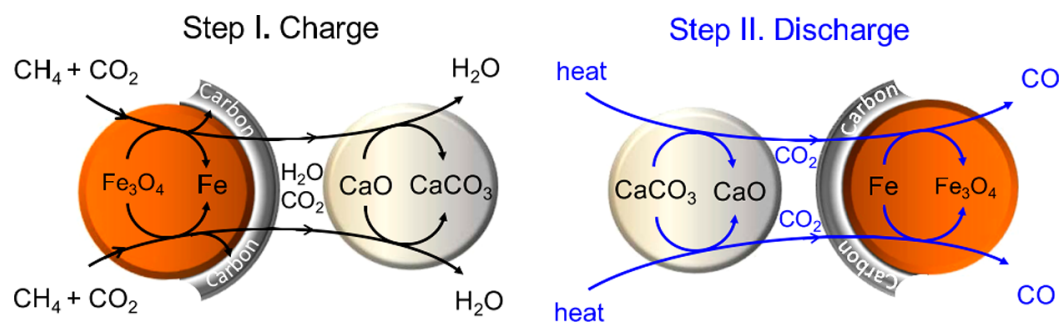

Figure 7. Schematic representation of the combined chemical looping process proposed by Galvita and co-workers. This chemical looping process, consisting of a charging and discharging step, could find its application in energy storage and conversion. Reprinted with permission from ref 158 . Copyright 2015 Elsevier. 
Compared to regular dry re-forming of methane, superdry reforming is a strongly intensified process as it converts up to three $\mathrm{CO}_{2}$ molecules per $\mathrm{CH}_{4}$. A schematic overview of the superdry re-forming process is presented in Figure 8. Recently,

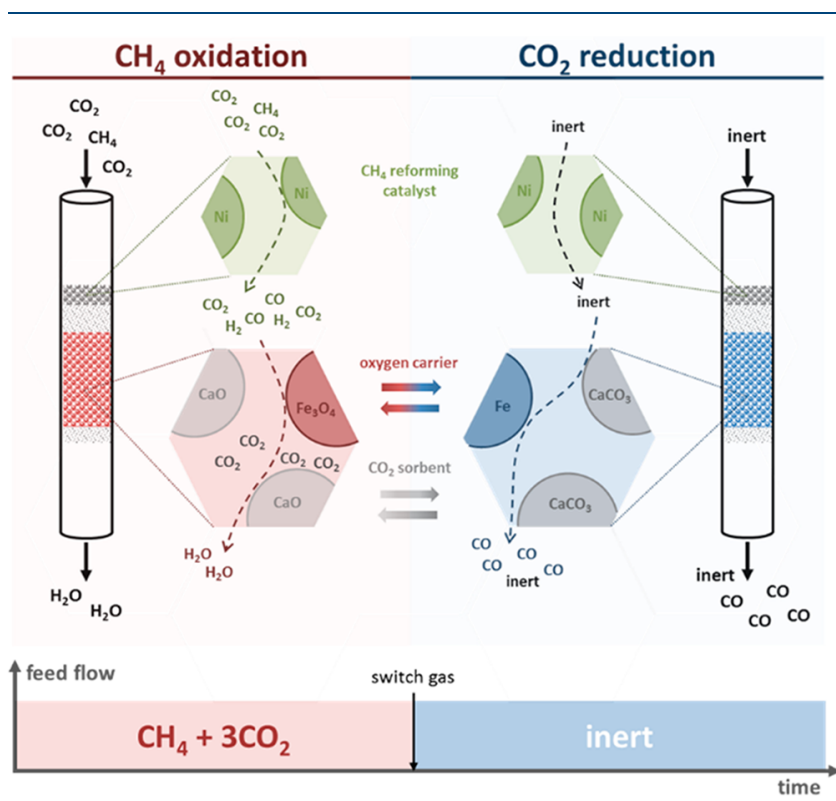

Figure 8. Schematic representation of the superdry re-forming process. In the $\mathrm{CH}_{4}$ oxidation step, $\mathrm{Ni}$ catalyzes the $\mathrm{CO}_{2}$ re-forming of $\mathrm{CH}_{4}$ into syngas, $\mathrm{Fe}_{3} \mathrm{O}_{4}$ is reduced by syngas with formation of $\mathrm{CO}_{2}$ and $\mathrm{H}_{2} \mathrm{O}$, and carbonation of $\mathrm{CaO}$ yields in situ $\mathrm{CO}_{2}$ removal. Overall, $\mathrm{CH}_{4}$ is oxidized into $\mathrm{CO}_{2}$ and $\mathrm{H}_{2} \mathrm{O}, \mathrm{Fe}_{3} \mathrm{O}_{4}$ has been reduced to $\mathrm{Fe}$ and $\mathrm{CaCO}_{3}$ has been formed from $\mathrm{CaO}$ and $\mathrm{CO}_{2}$. The $\mathrm{CO}_{2}$ reduction step consists of $\mathrm{CaCO}_{3}$ decomposition into $\mathrm{CaO}$ and $\mathrm{CO}_{2}$ and $\mathrm{Fe}$ oxidation to $\mathrm{Fe}_{3} \mathrm{O}_{4}$ through the reduction of $\mathrm{CO}_{2}$ into $\mathrm{CO}$. Reprinted with permission from ref 159. Copyright 2016 AAAS.

Kim and co-workers ${ }^{160}$ integrated $\mathrm{CO}_{2}$ capture and conversion and performed dry re-forming in which $\mathrm{CO}_{2}$ is fixed using $\mathrm{CaO}$ as sorbent in the first step. In the second step, the $\mathrm{CO}_{2}$ sorbent is regenerated, thereby releasing a stream of $\mathrm{CO}_{2}$ into a $\mathrm{CH}_{4}$ atmosphere, which is converted to a synthesis gas via DRM; i.e., sorbent regeneration and $\mathrm{CO}_{2}$ conversion are performed simultaneously.

4.3. Looping Materials. The previous paragraphs have focused on opportunities of using oxygen storage materials and $\mathrm{CO}_{2}$ sorbents in chemical looping processes (e.g., the inherent separation between products). This paragraph provides more information regarding the selection of a suitable looping material and the challenges associated with the use of looping materials.

4.3.1. Oxygen Storage Materials. The choice of the oxygen storage material depends highly on the chemical looping redox process, in particular the gaseous reactants. It is crucial that the chosen metal oxide oxidizes the reducing gas with a sufficient selectivity toward the desired gaseous product in the first step, while reducing the oxidizing gas with a sufficient selectivity toward the desired gaseous product in the second step. If kinetics and/or thermodynamics during the oxidation or reduction step are unfavorable for a certain metal oxide, its applicability in the chemical looping process is compromised. Typical oxygen storage materials for chemical looping combustion are based on transition metals (such as $\mathrm{Mn},^{98,161-166} \mathrm{Fe}{ }^{98,113,162-164,167-176} \mathrm{Co}{ }^{161,167,168,173,174}$ $\mathrm{Ni}{ }^{97,98,161-164,167,168,177}$ and $\mathrm{Cu}^{97,98,161-164}$ ) and/or their corresponding oxides, which can be periodically regenerated through reduction and oxidation cycles. The affinity of the reduced metal oxides toward oxygen and the ability of the oxidized metal oxides to oxidize fuels (such as $\mathrm{CH}_{4}$ or coal), either partially (into $\mathrm{CO}$ and $\mathrm{H}_{2}$ ) or fully (into $\mathrm{CO}_{2}$ and $\mathrm{H}_{2} \mathrm{O}$ ), make them ideal candidates for chemical looping combustion. The conversion of $\mathrm{H}_{2} \mathrm{O}$ or $\mathrm{CO}_{2}$ into $\mathrm{H}_{2}$ or $\mathrm{CO}$, however, can be realized by using oxygen storage materials based on $\mathrm{Mn}, \mathrm{Fe}$, and Co.

The thermodynamic (theoretical) oxygen storage capacity of an oxygen storage material depends on its capability to exchange oxygen during reduction and oxidation cycles. Figure 9 shows metal oxide pairs (e.g., $\mathrm{Fe} / \mathrm{Fe}_{3} \mathrm{O}_{4}$ ) and their Gibbs free

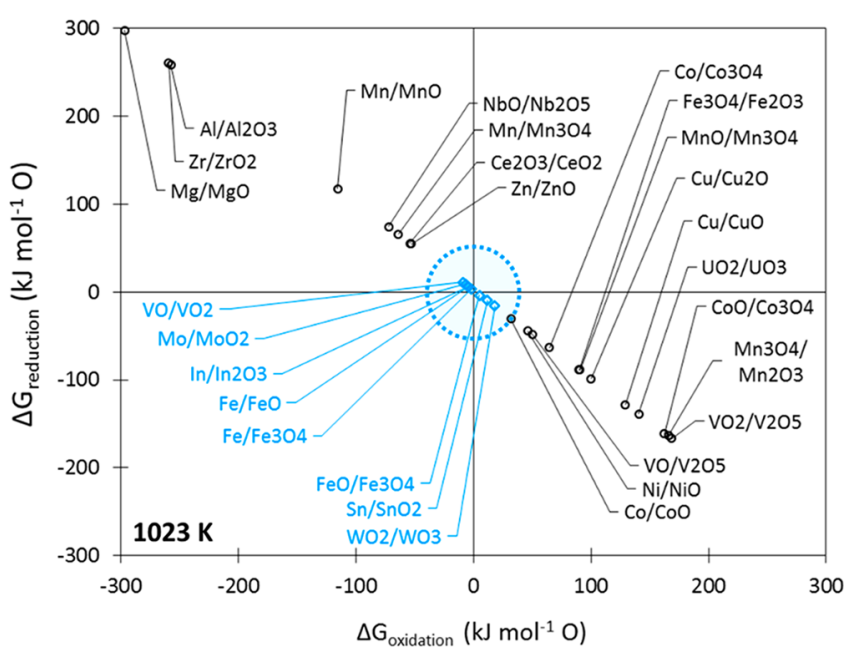

Figure 9. Thermodynamics study. Gibbs free energy of reduction by syngas ( $\mathrm{CO}: \mathrm{H}_{2}$ in a 1:1 molar ratio) as a function of the Gibbs free energy of reoxidation by $\mathrm{CO}_{2}$ for selected metal oxide pairs. The blue circle indicates the metal oxide pairs where reduction and oxidation can be considered sufficiently reversible for cyclic operation in a chemical looping redox process. Gibbs free energies were calculated at $1023 \mathrm{~K}$ using the reaction module in FactSage 6.4. ${ }^{181,182}$

energy of reduction (i.e., $\mathrm{Fe}_{3} \mathrm{O}_{4}$ reduction to $\mathrm{Fe}$ by syngas) and oxidation (i.e., $\mathrm{Fe}$ oxidation to $\mathrm{Fe}_{3} \mathrm{O}_{4}$ by $\mathrm{CO}_{2}$ ). Amid these metal oxide pairs, only the ones with Gibbs free energies sufficiently close to $0 \mathrm{~kJ} \mathrm{~mol}^{-1}$ in both the reduction and oxidation step (eqs 65 and 66) will be applicable for chemical looping redox reactions.

$$
\begin{aligned}
& 0.5 \mathrm{CO}_{(\mathrm{g})}+0.5 \mathrm{H}_{2(\mathrm{~g})}+\mathrm{M}_{x} \mathrm{O}_{y(\mathrm{~s})} \rightarrow 0.5 \mathrm{CO}_{2(\mathrm{~g})}+0.5 \mathrm{H}_{2} \mathrm{O}_{(\mathrm{g})} \\
& \quad+\mathrm{M}_{x} \mathrm{O}_{y-1(\mathrm{~s})} \Delta G_{\text {reduction }} \\
& \mathrm{CO}_{2(\mathrm{~g})}+\mathrm{M}_{x} \mathrm{O}_{y-1(\mathrm{~s})} \rightarrow \mathrm{CO}_{(\mathrm{g})}+\mathrm{M}_{x} \mathrm{O}_{y(s)} \quad \Delta G_{\text {oxidation }}
\end{aligned}
$$

Among the metal oxide pairs suitable for the conversion of $\mathrm{CO}_{2}$ into $\mathrm{CO}$ are the iron oxide-based materials. In order to further improve the properties an oxygen storage material, several active metal oxides can be combined. To this end, the application of ferrite spinel oxygen storage materials, including $\mathrm{MnFe}_{2} \mathrm{O}_{4}{ }^{178} \mathrm{CuFe}_{2} \mathrm{O}_{4},{ }^{179} \mathrm{CoFe}_{2} \mathrm{O}_{4}{ }^{123,180}$ and $\mathrm{NiFe}_{2} \mathrm{O}_{4}{ }^{123,180}$ has been proposed.

Even when the applied metal oxide initially shows favorable thermodynamics and kinetics for both redox steps, its applicability can be limited mainly due to three phenomena: (i) Thermodynamics dictates that the Gibbs free energy can 


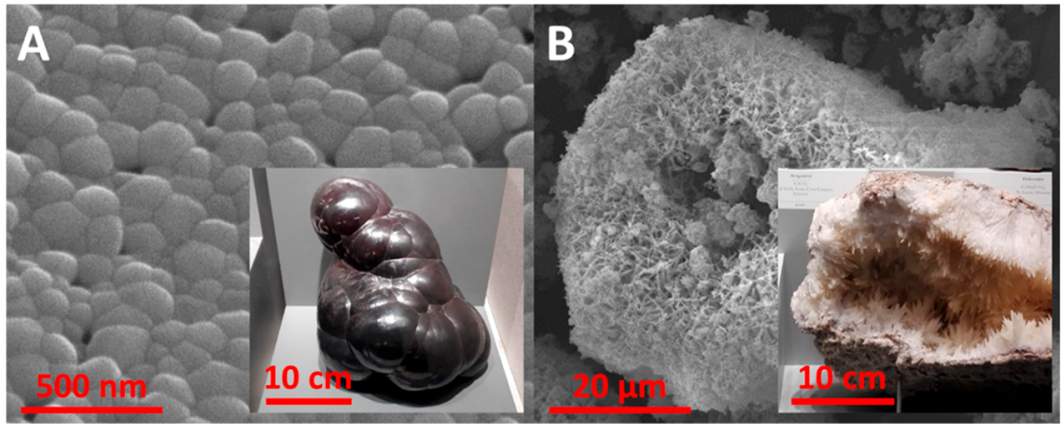

Figure 10. Illustration of crystallite growth. (A) Scanning electron micrograph of synthetic hematite $\left(\alpha\right.$ - $\left.\mathrm{Fe}_{2} \mathrm{O}_{3}\right)$ nanocrystals. The inset shows a photograph of macroscopic natural hematite crystals. (B) Scanning electron micrograph of synthetic aragonite $\left(\mathrm{CaCO}_{3}\right) \mathrm{crystals}$ The inset shows a photograph of macroscopic natural aragonite crystals. As natural crystals typically start off as small crystallite nuclei that grow slowly under favorable conditions (chemical environment, temperature, and pressure), the existence of such large natural crystals illustrates the thermodynamic driving force behind crystallite growth.

decrease by decreasing the gas-solid and solid-solid surface tension, i.e., by crystallite growth. This is illustrated by comparing synthetic nanocrystals with natural minerals that had hundreds if not thousands of years to grow (Figure 10). Indeed, while the shapes of these crystals are highly similar, the differences in the crystallite dimensions are tremendous. Together with the associated collapse of pore structure, crystallite growth may cause solid state ion diffusion limitations and gas phase product/reactant diffusion limitations. The phenomena of crystallite growth and collapsing pore structure are related to the occurrence of crystallographic phase transformations during reduction and oxidation as well as the melting temperature of these crystallographic phases. (ii) Gassolid or solid-solid shear forces may deteriorate the mechanical integrity of the oxygen storage material and lead to fines, which can be entrained by the gas flow. (iii) Poisoning of the metal (oxide) may occur, e.g., due to the presence of sulfur in the reducing gas or due to carbon formation.

In what follows, a brief review of methods for improving oxygen storage material properties is given. For a more extensive overview, the reader is referred elsewhere. ${ }^{124,127,183-186}$ In the 1990s and early 2000s, researchers focused on adding materials such as yttria-stabilized zirconia (YSZ), ${ }^{167,168,187} \mathrm{Al}_{2} \mathrm{O}_{3}{ }^{161-163,168,187} \mathrm{TiO}_{2}{ }^{162,168,187} \mathrm{MgO},{ }^{168}$ $\mathrm{NiAl}_{2} \mathrm{O}_{4},{ }^{163,168,177} \mathrm{Ni}-\mathrm{Mg}-\mathrm{Al}-\mathrm{O},{ }^{177}$ bentonite clay, ${ }^{188}$ sepiolite clay, ${ }^{162} \mathrm{SiO}_{2},{ }^{162,164} \mathrm{ZrO}_{2},{ }^{162}$ kaolinite clay, ${ }^{163} \mathrm{MnAl}_{2} \mathrm{O}_{4}{ }^{163}$ $\mathrm{CuAl}_{2} \mathrm{O}_{4}{ }^{163}$ and $\mathrm{MgAl}_{2} \mathrm{O}_{4}{ }^{164,170}$ to the redox-active metal oxide. Such additives were applied (i) as a way to increase the surface area available for reaction, (ii) as binder material enhancing the mechanical strength and attrition resistance, and (iii) as an ion conducting material. ${ }^{162}$ More recently, redoxactive additives such as $\mathrm{Ce}_{0.5} \mathrm{Zr}_{0.5} \mathrm{O}_{2}{ }^{113,171,172}$ and $\mathrm{CeO}_{2}{ }^{171,175,180,189}$ have been proposed to further improve the overall performance of the oxygen storage material. The schematic representation in Figure 11 illustrates the effect of mixing different oxides on the crystallite size and morphology of oxygen storage materials.

Even though the addition of above-mentioned metal oxides improves the physical properties, resistance, and is sometimes also found to mitigate poisoning of the oxygen storage material, ${ }^{177}$ it may give rise to deactivation through formation of undesired (crystalline) phases. When $\mathrm{Al}_{2} \mathrm{O}_{3}$ or $\mathrm{MgO}$ is used as an iron oxide additive, for example, $\mathrm{FeAl}_{2} \mathrm{O}_{4}$ and $\mathrm{MgFe}_{2} \mathrm{O}_{4}$ may be formed. ${ }^{176,180}$ Similarly, the addition of $\mathrm{CeO}_{2}$ may result in the formation of $\mathrm{CeFeO}_{3} \cdot{ }^{171,189}$ Formation of such

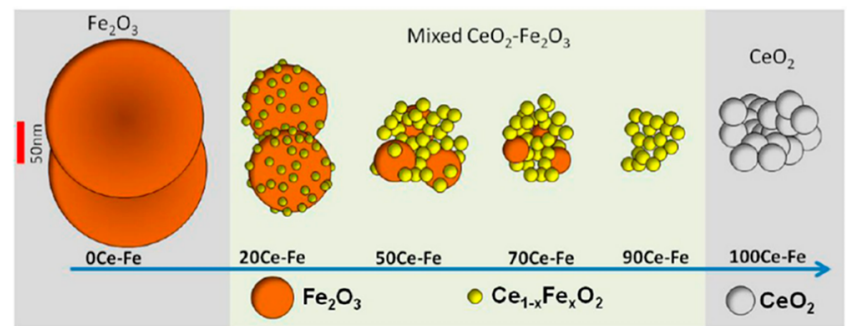

Figure 11. Schematic illustration of mixed $\mathrm{CeO}_{2}-\mathrm{Fe}_{2} \mathrm{O}_{3}$ samples. The illustration, based on ICP composition, XRD, STEM-EDX, and EELS, shows the effect of the $\mathrm{CeO}_{2}$ and $\mathrm{Fe}_{2} \mathrm{O}_{3}$ content on the crystallite size and morphology. Reprinted with permission from ref 175. Copyright 2013 American Chemical Society.

phases can cause deactivation either by decreasing the change in $\mathrm{Fe}$ oxidation state-and, hence, the amount of oxygen exchange-during redox cycling or by losing its redox capacity all together. ${ }^{176,180,189}$ A possible strategy for mitigating such a phenomenon is the addition of another metal oxide, e.g., by combining iron oxide with $\mathrm{MgO}$ and $\mathrm{Al}_{2} \mathrm{O}_{3}$ in order to form $\mathrm{MgAl}_{2} \mathrm{O}_{4}$ rather than $\mathrm{MgFe}_{2} \mathrm{O}_{4}$ or $\mathrm{FeAl}_{2} \mathrm{O}_{4}$.

Another class of oxygen storage materials that has been increasingly studied by researchers during the past decade, relies on the redox properties of stable crystallographic structures such as perovskites. Examples of investigated perovskites are $\mathrm{La}_{x} \mathrm{Sr}_{1-x} \mathrm{Fe}_{y} \mathrm{Co}_{1-y} \mathrm{O}_{3-\delta}$, ${ }^{173,174}$ $\mathrm{La}_{x} \mathrm{Sr}_{1-x} \mathrm{FeO}_{3-\delta},{ }^{173,174} \mathrm{LaFeO}_{3-\delta},{ }^{173} \mathrm{LaMnO}_{3},{ }^{190}$ $\mathrm{Dy}_{1-x} \mathrm{Y}_{x} \mathrm{MnO}_{3+\delta},{ }^{165} \mathrm{CaMn}_{0.875} \mathrm{Ti}_{0.125} \mathrm{O}_{3},{ }^{166}$ and $\mathrm{CaMn}_{0.875-\mathrm{x}} \mathrm{Fe}_{x} \mathrm{Ti}_{0.125} \mathrm{O}_{3-\delta} .{ }^{191}$ Additionally, the behavior of the $\mathrm{MgFeAlO}_{x}{ }^{176,180,192}$ spinel in $\mathrm{MgAl}_{2} \mathrm{O}_{4}$-promoted iron oxide has been studied. The benefit of these perovskite and spinel structures lies in their high oxygen mobility with limited crystallographic transformation, which results in a stable redox activity during high-temperature redox cycling. Recently, an extensive stability study over 1000 redox cycles was performed on three $\mathrm{Fe}_{2} \mathrm{O}_{3} / \mathrm{MgAlO}_{x}$ oxygen storage materials ${ }^{192}$ which form $\mathrm{Mg}-\mathrm{Fe}-\mathrm{Al}-\mathrm{O}$ spinels. Superior properties were found for 10 wt $\% \mathrm{Fe}_{2} \mathrm{O}_{3} / \mathrm{MgAlO}_{x}$, with the highest morphological stability and activity, while 50 wt $\% \mathrm{Fe}_{2} \mathrm{O}_{3} / \mathrm{MgAlO}_{x}$ had the best $\mathrm{CO}$ yield. All three materials deactivated through sintering, though less for 10 wt $\% \mathrm{Fe}_{2} \mathrm{O}_{3} / \mathrm{MgAlO}_{x}$. In addition, transformation to a $\mathrm{Mg}_{x} \mathrm{Fe}_{1-x} \mathrm{O}$ phase caused a loss of oxygen storage capacity in 30 and 50 wt $\% \mathrm{Fe}_{2} \mathrm{O}_{3} / \mathrm{MgAlO}_{x}$. In a follow-up to this stability study, detailed Mössbauer spectros- 
copy and in situ XRD studies were combined to provide new insight in the evolution of the redox behavior of 50 wt \% $\mathrm{Fe}_{2} \mathrm{O}_{3} / \mathrm{MgAlO}_{x}$ over the course of 1000 redox cycles. ${ }^{193}$ It was shown that at least three different oxygen storage cycles could be distinguished, as illustrated in Figure 12.

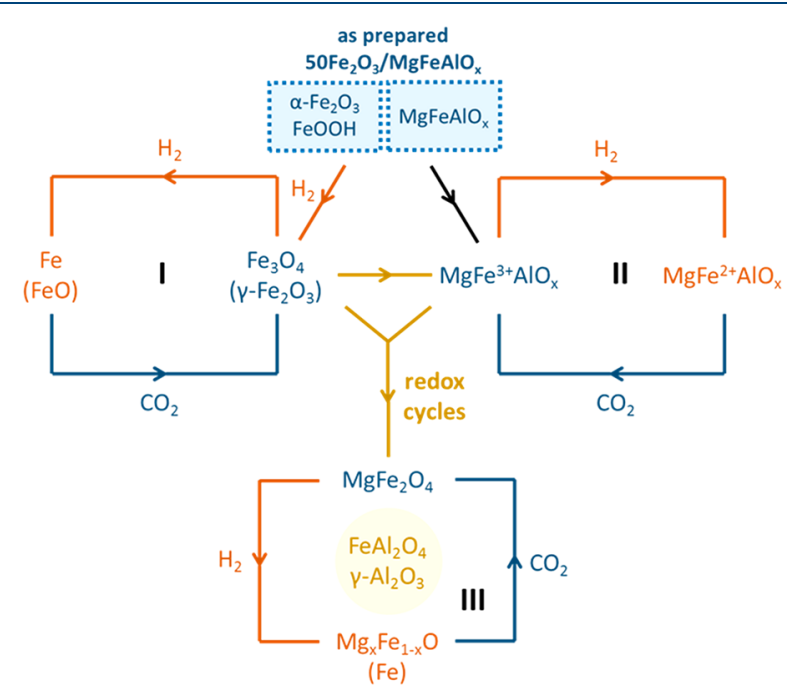

Figure 12. Schematic overview of redox activity over 1000 redox cycles. Effect of redox cycles on the oxygen storage behavior of $50 \mathrm{Fe}_{2} \mathrm{O}_{3} / \mathrm{MgFeAlO}_{x}$. As prepared OSM consists of $\alpha-\mathrm{Fe}_{2} \mathrm{O}_{3}, \alpha$ $\mathrm{FeOOH}$, and $\mathrm{MgFe}^{3+} \mathrm{AlO}_{x}$. Different redox-active species, categorized in three different redox loops, come into play upon redox cycling. Reprinted with permission from ref 193. Copyright 2019 American Chemical Society.

Other strategies for mitigating crystallite growth include the coating of active metal oxide particles with mesoporous inert metal oxides, such as $\mathrm{SiO}_{2}$-coated $\mathrm{LaMnO}_{3},{ }^{190} \mathrm{SiO}_{2}$-coated $\mathrm{Fe}_{2} \mathrm{O}_{3}{ }^{120}$ and $\mathrm{ZrO}_{2}$-coated $\mathrm{Fe}_{2} \mathrm{O}_{3}{ }^{194,195}$ An example of an advanced bifunctional oxygen storage material applied in catalyst-assisted chemical looping is presented in Figure 13.

For a more extensive overview dedicated to the synthesis and oxygen exchange mechanism of advanced materials for chemical looping applications, the interested reader is referred elsewhere. $^{86,124}$

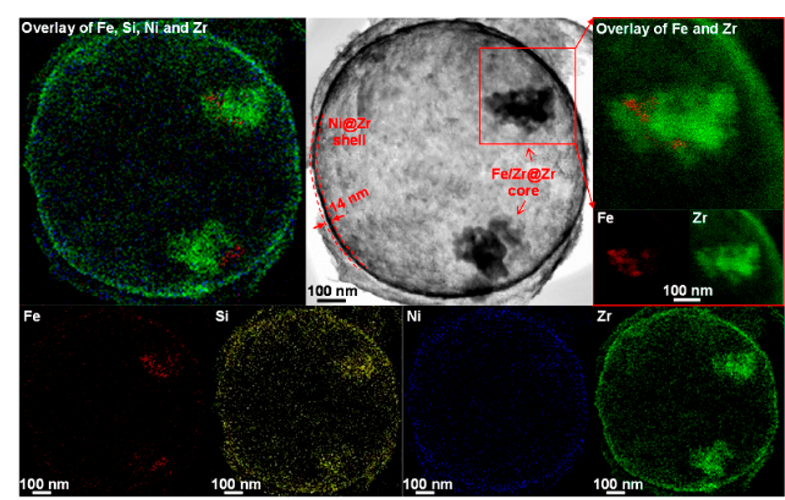

Figure 13. STEM-EDX characterization of a core-shell bifunctional nanomaterial. This advanced bifunctional Fe/Zr@Zr-Ni@Zr material consists of a $\mathrm{ZrO}_{2}$-coated nickel outer shell, encapsulating a $\mathrm{Fe}_{2} \mathrm{O}_{3}$ / $\mathrm{ZrO}_{2}$ (core) $-\mathrm{ZrO}_{2}$ (shell) oxygen storage material. Reprinted with permission from ref 195. Copyright 2018 MDPI.
4.3.2. Carbon Dioxide Sorbent Materials. Criteria for the choice of a carbon dioxide sorbent material and challenges with respect to its performance are very similar to those discussed for oxygen storage materials in the previous paragraph. Analogously, the active metal oxides (most commonly (earth) alkali metal oxides) were initially proposed to be used in form of natural minerals, e.g., limestone or dolomite. Most of the synthetic carbon dioxide sorbent materials are based on the carbonation-decarbonation equilibrium of $\mathrm{Li}_{2} \mathrm{O},{ }^{144,196-208} \mathrm{MgO},{ }^{209-214}$ or CaO. ${ }^{145,215-235}$ The optimal operating temperature of a carbon dioxide sorbent material is highly dependent on the chosen (earth) alkali metal, as illustrated by Figure 14 and Figure 15.

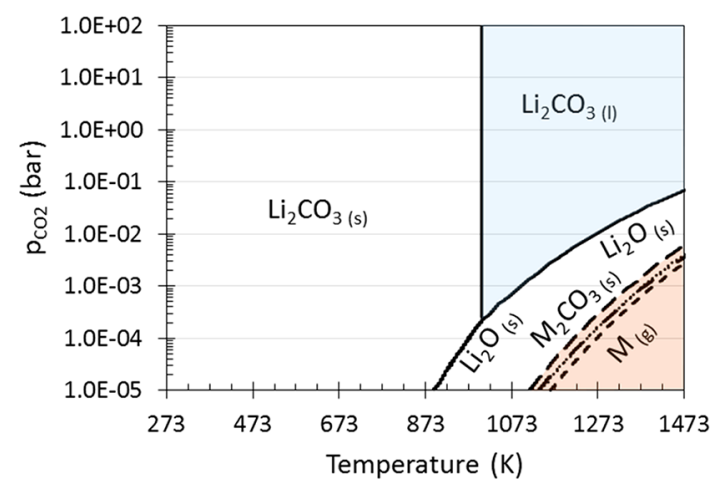

Figure 14. Thermodynamics study. Phase diagram showing the carbonation-decarbonation equilibrium of alkali metal oxides as a function of temperature and $\mathrm{CO}_{2}$ partial pressure: $(-) \mathrm{Li}_{2} \mathrm{CO}_{3(\mathrm{~s})}-$ $\mathrm{Li}_{2} \mathrm{CO}_{3(1)}-\mathrm{Li}_{2} \mathrm{O}_{(\mathrm{s})} ;(---) \mathrm{Na}_{2} \mathrm{CO}_{3(\mathrm{~s})}-\mathrm{Na}_{(\mathrm{g})} ;(\cdots) \mathrm{K}_{2} \mathrm{CO}_{3(\mathrm{~s})}-\mathrm{K}_{(\mathrm{g})}$; (-.) $\mathrm{Cs}_{2} \mathrm{CO}_{3(\mathrm{~s})}-\mathrm{Cs}_{(\mathrm{g})}$; (--) $\mathrm{Rb}_{2} \mathrm{CO}_{3(\mathrm{~s})}-\mathrm{Rb}_{(\mathrm{g}}$. Phase diagrams were calculated using the phase diagram module in FactSage 6.4. ${ }^{181,182}$

The phase diagram, presented in Figure 14, indicates the equilibrium lines between carbonation and decarbonation of pure alkali metal oxides. While the $\mathrm{Li}_{2} \mathrm{CO}_{3}-\mathrm{Li}_{2} \mathrm{O}$ equilibrium could be of interest for cyclic $\mathrm{CO}_{2}$ uptake and release, other alkali metal oxides vaporize at conditions where decarbonation is favorable. Making use of $\mathrm{Li}_{2} \mathrm{O}$ as such, however, may be equally challenging due to the favorability of liquid $\mathrm{Li}_{2} \mathrm{CO}_{3}$ formation at elevated temperature and $\mathrm{CO}_{2}$ partial pressure.

In view of vaporization and liquefaction, earth alkali metal oxides provide a more workable alternative. Phase diagrams for the equilibrium between carbonation and decarbonation of earth alkali metal oxides are presented in Figure 15A. At low temperatures and elevated partial pressures of water vapor, however, their effective use can be impaired through formation of hydroxides. This is illustrated by the phase diagrams in Figure 15B, which show that liquid state hydroxides may even be formed when exposing $\mathrm{SrO}$ or $\mathrm{BaO}$ to high water vapor pressures. The use of earth alkali metal oxides is therefore limited to a temperature window with a lower limit determined by (i) carbonation kinetics and (ii) hydroxide formation, and an upper limit governed by the decarbonation temperature.

Instead of choosing a different class of materials all together, the issues of vaporization and liquefaction raised for the alkali metal oxides can be (partially) addressed by incorporation of these alkali metal oxides into a stable framework, e.g., in the form of silicates. Phase diagrams for the carbonation and decarbonation of $\mathrm{Li}_{2} \mathrm{ZrO}_{3}, \mathrm{Li}_{4} \mathrm{SiO}_{4}, \mathrm{Na}_{4} \mathrm{SiO}_{4}$, and $\mathrm{K}_{4} \mathrm{SiO}_{4}$ are presented in Figure 16, showing significantly different 
A

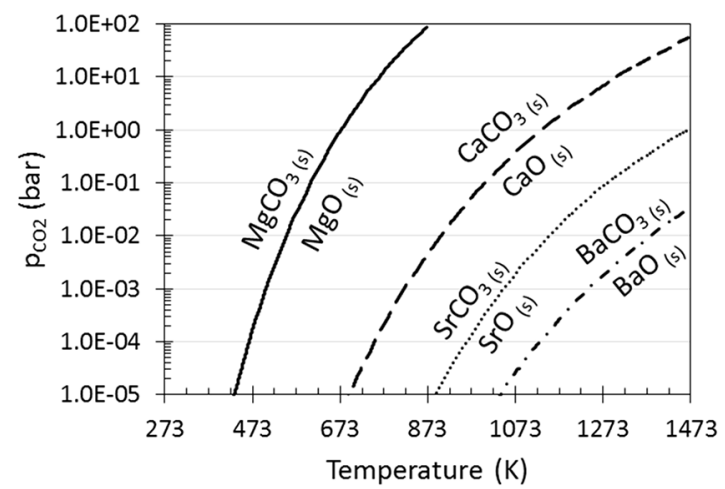

B

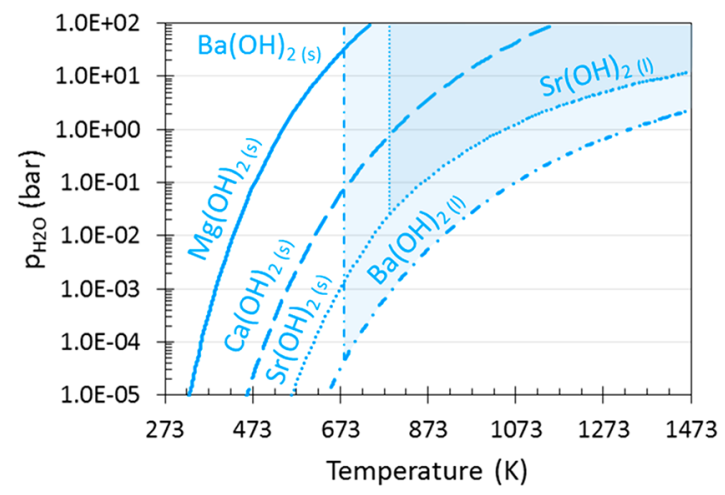

Figure 15. Thermodynamics studies. (A) Phase diagram of earth alkali metal oxides and their carbonates as a function of temperature and $\mathrm{CO}_{2}$ partial pressure: (-) $\mathrm{MgCO}_{3}-\mathrm{MgO}$; (--) $\mathrm{CaCO}_{3}-\mathrm{CaO}$; (...) $\mathrm{SrCO}_{3}-\mathrm{SrO}$; (-.-) $\mathrm{BaCO}_{3}-\mathrm{BaO}$. (B) Phase diagram of earth alkali metal hydroxides and their corresponding oxides (omitted for clarity) as a function of temperature and $\mathrm{H}_{2} \mathrm{O}$ partial pressure: (-) $\mathrm{Mg}(\mathrm{OH})_{2(\mathrm{~s})}-\mathrm{MgO}_{(\mathrm{s})} ;(--) \mathrm{Ca}(\mathrm{OH})_{2(\mathrm{~s})}-\mathrm{CaO}_{(\mathrm{s})} ;(\cdots) \mathrm{Sr}(\mathrm{OH})_{2(\mathrm{~s})}-$ $\mathrm{Sr}(\mathrm{OH})_{2(1)}-\mathrm{SrO}_{(\mathrm{s})} ;(-\cdot-) \mathrm{Ba}(\mathrm{OH})_{2(\mathrm{~s})}-\mathrm{Ba}(\mathrm{OH})_{2(1)}-\mathrm{BaO}_{(\mathrm{s})}$. Phase diagrams were calculated using the phase diagram module in FactSage 6.4. ${ }^{181,182}$

behaviors compared with the alkali metal oxides as such (Figure 14).

Indeed, lithium oxide-based sorbents are typically stabilized by formation of $\mathrm{Li}_{2} \mathrm{ZrO}_{3}{ }^{144,196-198}$ or $\mathrm{Li}_{4} \mathrm{SiO}_{4},{ }^{199-206}$ and less commonly in form of $\mathrm{Li}_{2} \mathrm{Fe}_{2} \mathrm{O}_{4}{ }^{207}$ or $\mathrm{Li}_{4+x}\left(\mathrm{Si}_{1-x} \mathrm{Al}_{x}\right) \mathrm{O}_{4}{ }^{208}$ The most studied promoter materials are $\mathrm{K}_{2} \mathrm{CO}_{3}{ }^{198,201-204}$ and $\mathrm{Na}_{2} \mathrm{CO}_{3},{ }^{203-205}$ both of which actively contribute to the carbon dioxide storage capacity. Advanced methods for improving the stability of, e.g., $\mathrm{Li}_{4} \mathrm{SiO}_{4}$ include its coating with a $\mathrm{Li}_{2} \mathrm{ZrO}_{3}$ layer to form a $\mathrm{Li}_{4} \mathrm{SiO}_{4} @ \mathrm{Li}_{2} \mathrm{ZrO}_{3}$ sorbent material (STEM-EDX image presented in Figure 17A). ${ }^{236}$ Figure 17B illustrates the improvement in the cyclic stability of a $\mathrm{Li}_{4} \mathrm{SiO}_{4}$ sorbent after coating with $\mathrm{Li}_{2} \mathrm{ZrO}_{3}$.

Magnesia-based sorbents are most often modified with $\mathrm{Al}_{2} \mathrm{O}_{3},{ }^{211-214}$ thereby forming a hydrotalcite-like structure, and/or with $\mathrm{K}_{2} \mathrm{CO}_{3}{ }^{209-211}$ While many different additives for calcium oxide-based sorbents have been studied, $\mathrm{Al}_{2} \mathrm{O}_{3}{ }^{216-229}$ and $\mathrm{ZrO}_{2}{ }^{230-235}$ are by far the most widely studied. In the presence of $\mathrm{CaO}$, these metal oxides are typically transformed into $\mathrm{Ca}_{12} \mathrm{Al}_{14} \mathrm{O}_{33}$ and $\mathrm{CaZrO}_{3}$. For a more elaborate overview of carbon dioxide sorbent materials, the reader is referred elsewhere. $^{237-244}$

4.3.3. Economic and Environmental Considerations. When choosing a looping material, economic and environ- mental aspects should be considered. As previously mentioned, the activity and stability of the material are highly important properties in view of process economics. Tailored material synthesis, however, can lead to a high cost of material production owing to complexity in the synthesis procedure or the use of expensive (precursor) materials.

Improving the economics and sustainable nature of the synthesis procedure necessitates the minimization of required resources such as solvents, energy, time, and chemicals (e.g., surfactants). The use of solvents and nonessential chemicals should be minimized as these substances will not end up in the final material but are removed during the synthesis procedure instead, weighing on the process economics through energy consumption and waste production. Toxic substances should be avoided where possible.

An indication for the cost of metals and their oxides can be obtained from their percent elemental abundancy in the Earth's crust (Figure 18). As a rule of thumb, abundant materials such silica, alumina, iron oxide, calcium oxide, magnesium oxide, sodium oxide, and potassium oxide are cheap, as they comprise more than $99 \%$ of the Earth's crust. Of the remaining $1 \%$, about $60 \%$ consists of titanium oxide and manganese oxide as well as other (transition) metals with lower abundancy. The group of rare-earth materials such as ceria, neodymium oxide, and lanthanum oxide represents about $1 \%$ of $1 \%$ of the Earth's crust. The estimated abundancy of all noble metals together, silver and iridium being the most and least common, adds up to about $0.001 \%$ of $1 \%$ of the Earth's crust (roughly $100 \mathrm{ppb}$ ).

In conclusion, an optimum should be found when highly stable materials are expensive to produce, while less stable materials are cheap to produce but expensive to dispose of economically and/or environmentally.

4.4. Reactor Configurations. Along with an appropriate choice of chemical looping material, the reactor configuration choice is vital for the practical realization of chemical looping processes. In 1920, Abbott proposed a multireactor configuration using four reactors-each packed with an iron oxide bed-and switching valves in order to realize continuous hydrogen production through the steam-iron process with an improved heat integration (Figure 19A). ${ }^{246}$ Two decades later, Walton H. Marshall patented a continuous reactor setup (Figure 19B) for the steam-iron process, in which transportation and reaction of iron oxide occur simultaneously in an oxidizing and reducing coil, each time followed by a separation between the solid phase and the gas phase. ${ }^{247}$ The dual fluidized bed reactor setup (Figure 19C) for the steam-iron process was patented by Barr in $1948 .{ }^{248}$ In 1954, a moving bed reactor setup (Figure 19D) was patented by Lewis and Gilliland for the production of $\mathrm{CO}_{2}$ from carbonaceous fuels. ${ }^{91}$

More recently, in 2014, Dahl and Blom patented a rotating reactor (Figure 19E) for chemical looping combustion. ${ }^{249}$ A different type of rotating reactor, in which the oxygen storage material is fixed by coating onto porous structure, has been proposed by Zhao and co-workers. ${ }^{251,252}$

In what follows, some of the main advantages and challenges of different reactor configurations are discussed. A strong advantage of the dual fluidized bed reactor, suspension reactor, moving bed reactor, and rotary reactor configuration is the possibility to run the chemical looping process continuously. As for the multireactor configuration, a semicontinuous operation can be realized in the so-called permanent periodic regime. 
A

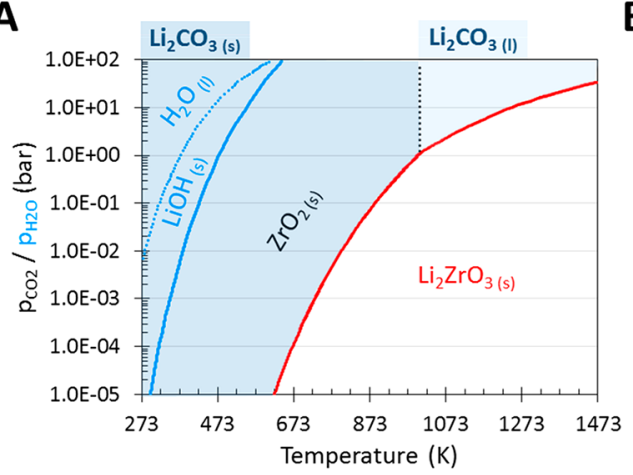

C

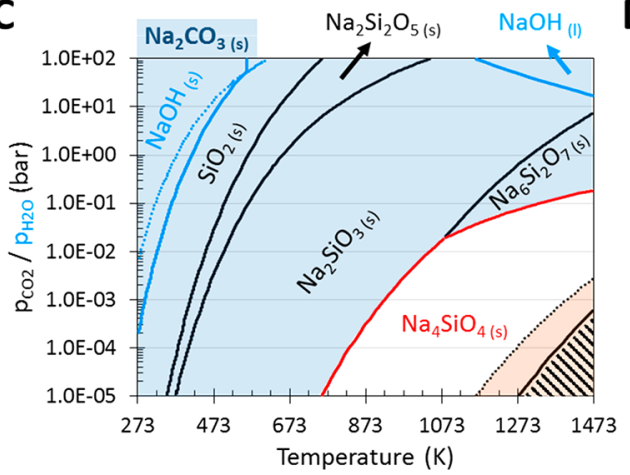

B

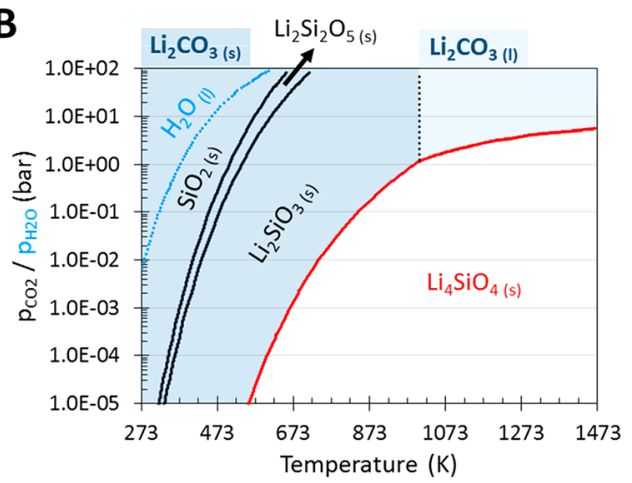

D

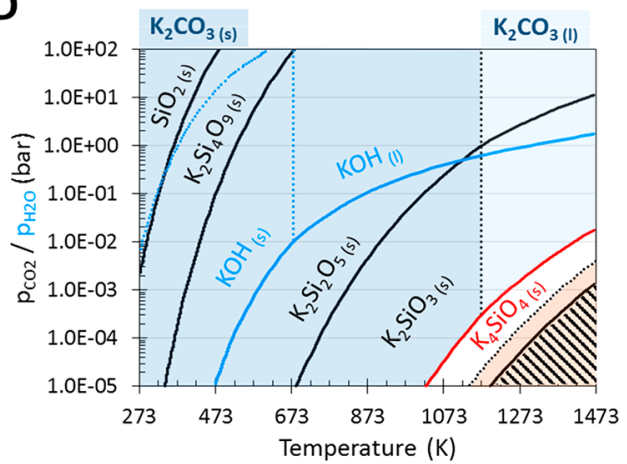

Figure 16. Thermodynamics studies. Phase diagram of alkali metal oxides and their carbonates (or hydroxides) as a function of temperature and $\mathrm{CO}_{2}$ (or $\mathrm{H}_{2} \mathrm{O}$ ) partial pressure: (A) $\mathrm{Li}_{2} \mathrm{ZrO}_{3}$; (B) $\mathrm{Li}_{4} \mathrm{SiO}_{4}$; (C) $\mathrm{Na}_{4} \mathrm{SiO}_{4}$; (D) $\mathrm{K}_{4} \mathrm{SiO}_{4}$. Blue lines correspond to the equilibrium between hydroxides and oxides under $\mathrm{H}_{2} \mathrm{O}$ pressure. Red lines correspond to the equilibrium between $\mathrm{CO}_{2}$ uptake and full $\mathrm{CO}_{2}$ release. Dotted lines represent solidliquid-gas phase transformations. The gray shaded area corresponds to conditions where carbonate formation is favorable. The orange shaded area corresponds to conditions where alkali vapor is formed in case alkali metal oxides are used as such (Figure 14). The stripe-shaded area corresponds to conditions where alkali vaporization is favorable and depletion of alkali in the solid silicate occurs. Phase diagrams were calculated using the phase diagram module in FactSage 6.4. ${ }^{181,182}$
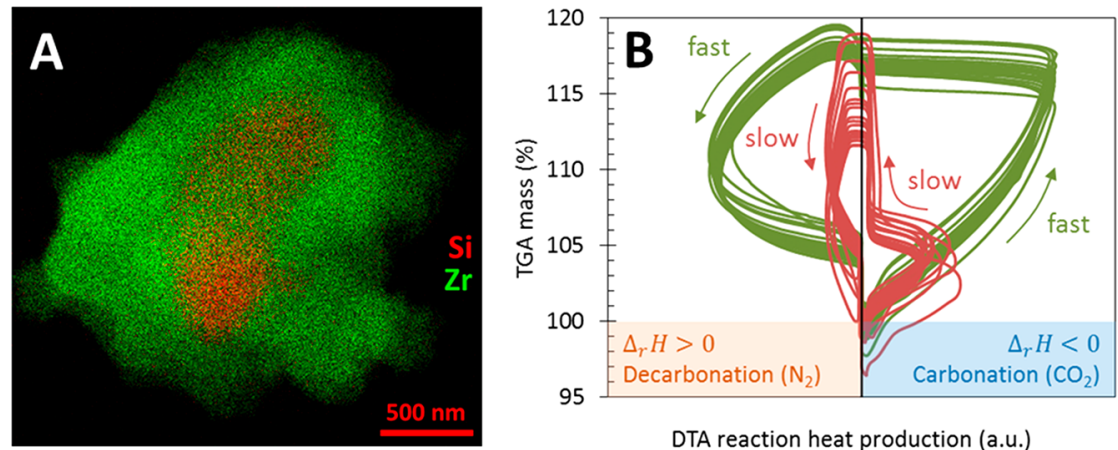

Figure 17. Characterization of a $\mathrm{Li}_{2} \mathrm{ZrO}_{3}$-coated $\mathrm{Li}_{4} \mathrm{SiO}_{4}$ carbon dioxide sorbent. (A) STEM-EDX elemental map of $\mathrm{Li}_{2} \mathrm{ZrO}_{3}$-coated $\mathrm{Li}_{4} \mathrm{SiO}_{4}$. (B) TGA-DTA analysis of 20 carbonation-decarbonation cycles of $\mathrm{Li}_{4} \mathrm{SiO}_{4}$ (red) and $\mathrm{Li}_{4} \mathrm{SiO}_{4} @ \mathrm{Li}_{2} \mathrm{ZrO}_{3}$ (green). Reprinted with permission from ref 236. Copyright 2019 Elsevier.

The dual fluidized bed reactor, suspension reactor, and moving bed reactor are highly favorable in terms of mass and heat transfer but pose stringent requirements in terms of mechanical strength and attrition resistance of the solid looping materials due to considerable gas-solid and solidsolid shear forces. Moreover, efficient solid-gas separation units (e.g., cyclones) should be available in order to successfully operate such a reactor configuration. Over the past two decades, the dual fluidized bed and moving bed have been the reactor configurations of choice for many researchers studying different kinds of chemical looping processes from a theoretical and experimental point of view. ${ }^{112,125,128,145,253-273}$ A clear advantage of the dual fluidized bed configuration is the available knowledge and experience from its application in fluid catalytic cracking. As for the moving bed reactor configuration, the possibility to operate it in countercurrent allows higher conversions at lower recirculation rate of the solids. ${ }^{125,128}$ For the regeneration of carbon dioxide sorbent material in chemical looping carbon dioxide separation, rotary kilns (Figure 19F) have also been used. ${ }^{128,260}$ Such a rotary kiln, commonly used for the industrial calcination of limestone, ${ }^{128}$ can be described as a rotating moving bed reactor, slowly transporting solid looping material while ensuring a good contact with the gas phase.

The rotating reactor aims to intensify the process by providing a more compact configuration that eliminates the 

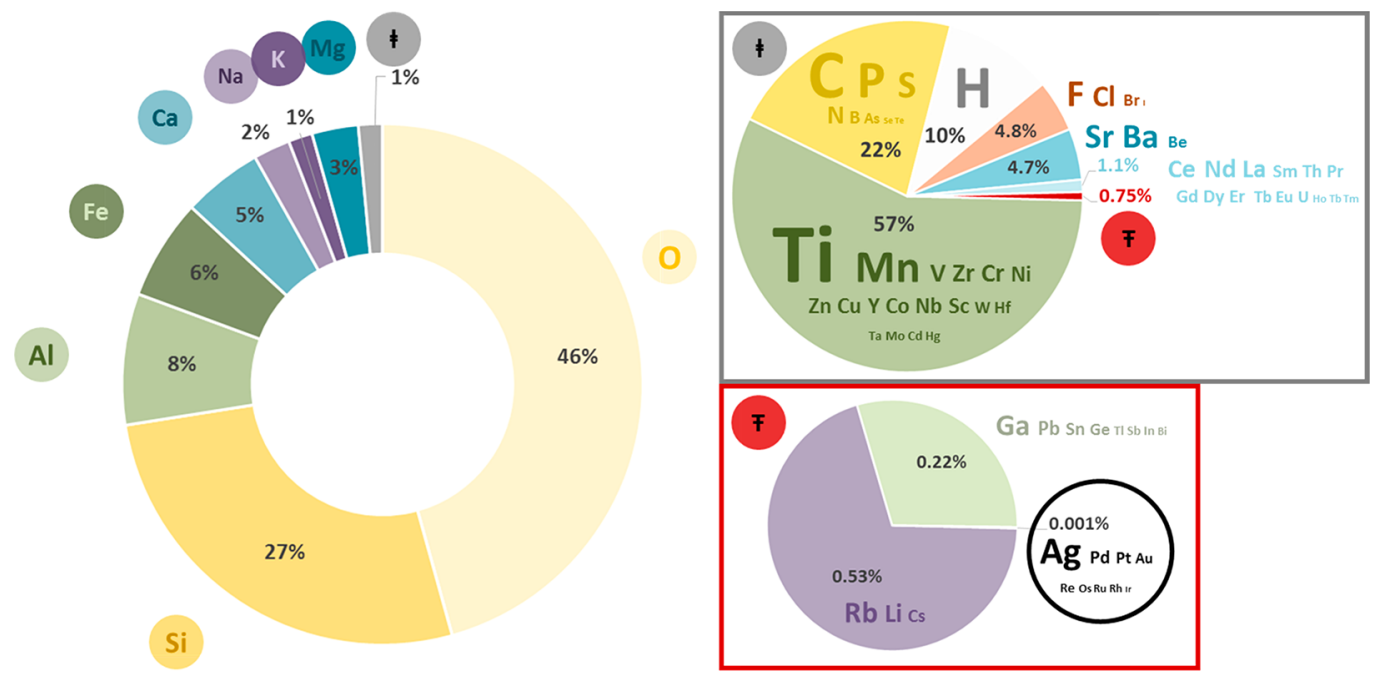

Figure 18. Abundancy of elements in the Earth's crust. Overview of the percent abundancy of elements in the Earth's crust. (Top right) Percentages in this pie chart add up to $100 \%$, which corresponds with $1 \%$ of the total abundancy of elements in the Earth's crust. (Bottom right) Percentages in this pie chart add up to $0.75 \%$ and further divides the smallest slice in the top right chart. Reprinted with permission from ref 245 .

need for separation between solids and gases. ${ }^{274} \mathrm{~A}$ drawback of the reactor configuration proposed by Zhao and co-work$\operatorname{ers}^{251,252}$ is the requirement of an immobilized solid looping material, e.g., by coating it onto a porous substrate, which may pose restrictions with respect to the application of solid looping materials. Moreover, temperature fluctuations in different reactor zones may cause significant stress levels on the reactor system by position-dependent expansion. ${ }^{252}$ As for the rotating reactor configuration proposed by Dahl, Blom, and co-workers, ${ }^{24,275,276}$ the optimal performance in terms of product gas separation remains uncertain.

The multibed reactor configuration avoids high shear forces and therefore poses milder requirements in terms of attrition resistance of the looping material. ${ }^{277}$ Moreover, it allows us to reach deeper reduction and oxidation of the oxygen storage material. ${ }^{277}$ By choosing a cocurrent or countercurrent regeneration of the looping material, the process efficiency can be optimized. ${ }^{278,279}$ As previously mentioned, a drawback of such a system is that it can be operated only semicontinuously and requires intensive use of switching valves, typically at high temperature and pressure. ${ }^{277}$

Overall, the choice of reactor configuration strongly affects the requirements for the solid looping material. A long lifetime of the looping material, the heart of the chemical looping process, is primordial for successful operation. To this end, the development of attrition-resistant looping materials, e.g., through spray-drying synthesis, ${ }^{280,281}$ is a crucial step toward commercialization of a dual fluidized bed chemical looping process. For a detailed overview of progress and challenges in scale-up of chemical looping processes, the interested reader is referred elsewhere. ${ }^{127,130,258,260,272,282}$

\section{CONCLUSION AND PERSPECTIVE}

During the past centuries, mankind has improved its quality of life by making use of a seemingly endless source of fossil resources for energy production. Today, the environmental impact, associated with the accumulation of anthropogenic $\mathrm{CO}_{2}$ emissions in atmosphere and oceans is of increasing concern for societies and hence governments. In the past decade, the sharp decrease in energy cost associated with wind and solar energy production has triggered the start of an energy revolution toward renewables. In the coming decades, electric vehicles are expected to stir up the transportation sector. Both evolutions seem favorable in terms of reducing anthropogenic $\mathrm{CO}_{2}$ emissions. Nevertheless, future challenges lie in reducing the carbon footprint of the (petro)chemical industry, and perhaps actively decreasing atmospheric $\mathrm{CO}_{2}$ concentrations. In this respect, carbon recycling by conversion of $\mathrm{CO}_{2}$ into useful chemicals or fuels may allow to close the carbon loop. A possible method for activating $\mathrm{CO}_{2}$ is its reduction into $\mathrm{CO}$ by means of a chemical reductant such as renewable $\mathrm{H}_{2}$ or $\mathrm{CH}_{4}$, e.g., obtained from biogas. To this end, iron oxide-based chemical looping redox processes provide interesting perspective.

Although the first description and application of chemical looping can be traced back to over a century ago, the last two decades have witnessed intensified research on chemical looping processes. In contrast with the early days of chemical looping, which saw huge challenges in obtaining a looping material, stable over the course of just several cycles, the ever increasing knowledge and expertise with respect to the synthesis, characterization and testing of functional nanomaterials in catalysis and materials science has strongly contributed to the progress made in the design of chemical looping materials that retain much of their activity over hundreds to thousands of cycles.

Simultaneously, researchers have developed innovative ways to apply of these looping materials for converting different types of feedstocks into a variety of products, or by combining different chemical looping processes to improve the overall performance. The strength of chemical looping indeed lies in its flexibility, which results from the fact that a single reaction is separated into two subreactions coupled through the oxygen carrier material. This specificity opens up a wide parameter space for design and optimization of reactor feed and process operation. In global perspective, the chemical looping principle should be fundamentally applicable to any catalytic reaction, if suitable carriers are found that allow transport of the desired functional group. The reagent and product separation that is inherent to this technology can have significant impact in the future on a broad range of chemical processes, yielding higher efficiency and "greener" chemistry. 

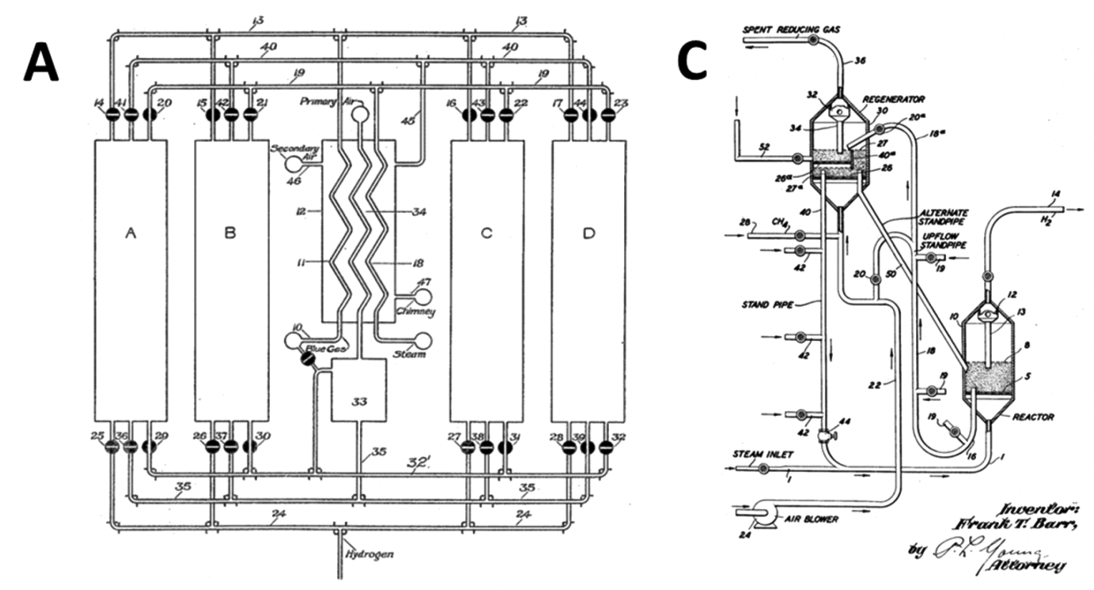

\section{B}
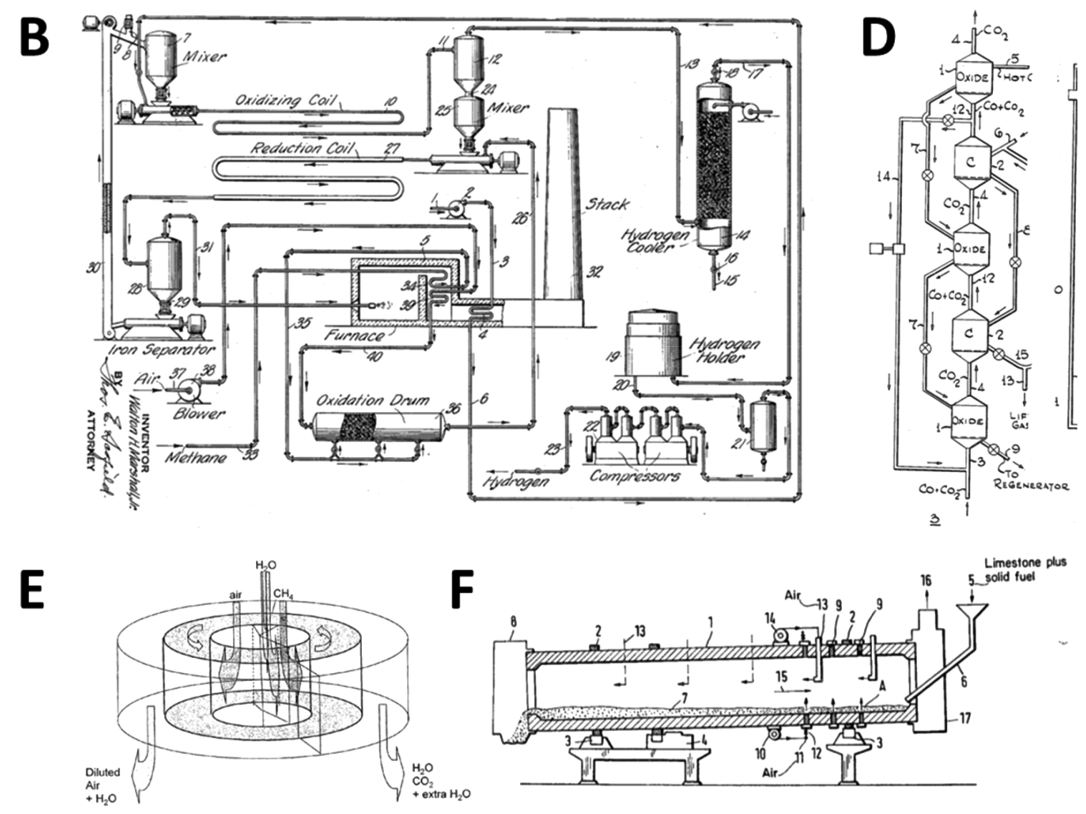

Figure 19. Schematic representation of chemical looping reactor configurations for continuous production. (A) Multireactor configuration, patented by Abbott. ${ }^{246}$ (B) Suspension reactor configuration with oxygen storage material transport through oxidizing and reduction coil, patented by Marshall. $^{247}$ (C) Dual fluidized bed reactor with oxygen storage material transport between the reactor and regenerator, patented by Barr. ${ }^{248}$ (D) Moving bed reactor for chemical looping $\mathrm{CO}_{2}$ production, patented by Lewis and Gilliland. ${ }^{91}$ (E) Rotating reactor for chemical looping combustion with inherent $\mathrm{CO}_{2}$ separation, patented by Dahl and Blom. ${ }^{249}$ (F) Rotary kiln for the calcination of limestone, patented by Gerhard Reuter and coinventors. ${ }^{250}$ Images were reprinted with permission from the cited patents.

\section{ASSOCIATED CONTENT}

\section{S Supporting Information}

The Supporting Information is available free of charge on the ACS Publications website at DOI: 10.1021/acs.iecr.9b02521.

Historical context 1, carbon dioxide and the environment; historical context 2: chemical looping (PDF)

\section{AUTHOR INFORMATION}

\section{Corresponding Author}

*E-mail: Vladimir.Galvita@UGent.be. Tel: +32-468-10-6004. Fax: +32-9331-1759.

\section{ORCID $\odot$}

Guy B. Marin: 0000-0002-6733-1213

Vladimir V. Galvita: 0000-0001-9205-7917

\section{Notes}

The authors declare no competing financial interest.

\section{ACKNOWLEDGMENTS}

This work was supported by the Long Term Structural Methusalem Funding of the Flemish Government and the Fund for Scientific Research Flanders (FWO; project G004613N). L. C. Buelens acknowledges financial support from the Institute for the Promotion of Innovation through Science and Technology in Flanders (IWT Vlaanderen).

\section{REFERENCES}

(1) Harris, D. F. The pioneer in the hygiene of ventilation. Lancet 1910, 176 (4542), 906-908.

(2) Almqvist, E. History of Industrial Gases; Springer, 2003; p 472.

(3) Black, J. Experiments upon magnesia alba, quicklime, and some other alcaline substances. Essays and Observations: Physical and Literary (Vol. 2); Philosophical Society of Edinburgh: Edinburgh, 1756; pp 157-225.

(4) West, J. B. Joseph Black, carbon dioxide, latent heat, and the beginnings of the discovery of the respiratory gases. American Journal of Physiology-Lung Cellular and Molecular Physiology 2014, 306 (12), 1057-1063. 
(5) Priestley, J., XIX. Observations on different kinds of air. Philosophical Transactions 1772, 62, 147-264.

(6) Ingenhousz, J. Experiments upon vegetables: discovering their great power of purifying the common air in the sun-shine, and of injuring it in the shade and at night: to which is joined, a new method of examining the accurate degree of salubrity of the atmosphere; Printed for P. Elmsly and H. Payne: London, 1779.

(7) Lavoisier, A. Traité Élementaire de Chimie, présenté dans un ordre nouveau, et d'après des découvertes modernes; L'Académie des Sciences \& de la Société Royale de Médecine: Paris, 1789.

(8) Dalton, J. A New System of Chemical Philosophy; Henderson \& Spalding: London, 1808.

(9) Fourier, J. Mémoire sur les Températures du Globe Terrestre et des Espaces Planétaires. Mémoires de l'Académie Royale des Sciences 1827, 7, 569-604.

(10) Fourier, J. Remarques Générales Sur Les Températures Du Globe Terrestre Et Des Espaces Planétaires. Annales de Chimie et de Physique 1824, 27, 136-167.

(11) Tyndall, J. On the Absorption and Radiation of Heat by Gases and Vapours, and on the Physical Connexion of Radiation, Absorption, and Conduction. Philosophical Transactions of the Royal Society of London 1861, 22, 273.

(12) Arrhenius, S., XXXI On the influence of carbonic acid in the air upon the temperature of the ground. London, Edinburgh, and Dublin Philosophical Magazine and Journal of Science 1896, 41 (251), 237276.

(13) Arrhenius, S. On the Influence of Carbonic Acid in the Air upon the Temperature of the Earth. Publ. Astron. Soc. Pac. 1897, 9 (54), 14.

(14) Hulburt, E. O. The Temperature of the Lower Atmosphere of the Earth. Phys. Rev. 1931, 38 (10), 1876-1890.

(15) Callendar, G. S. The artificial production of carbon dioxide and its influence on temperature. Q. J. R. Meteorol. Soc. 1938, 64 (275), 223-240.

(16) Plass, G. N. The Carbon Dioxide Theory of Climatic Change. Tellus 1956, 8 (2), 140-154.

(17) Revelle, R.; Suess, H. E. Carbon Dioxide Exchange Between Atmosphere and Ocean and the Question of an Increase of Atmospheric $\mathrm{CO}_{2}$ during the Past Decades. Tellus 1957, 9 (1), 1827.

(18) Brohan, P.; Kennedy, J. J.; Harris, I.; Tett, S. F. B.; Jones, P. D. Uncertainty estimates in regional and global observed temperature changes: A new data set from 1850. J. Geophys. Res. 2006, 111, D12106.

(19) Keeling, C. D. The Concentration and Isotopic Abundances of Atmospheric Carbon Dioxide in Rural Areas. Geochim. Cosmochim. Acta 1958, 13 (4), 322-334.

(20) Schneider, S. H. On the Carbon Dioxide-Climate Confusion. J. Atmos. Sci. 1975, 32 (11), 2060-2066.

(21) Manabe, S.; Wetherald, R. T. Thermal Equilibrium of the Atmosphere with a Given Distribution of Relative Humidity. J. Atmos. Sci. 1967, 24 (3), 241-259.

(22) Keeling, C. D. Carbon Dioxide from Fossil Fuel - its Effect on Natural Carbon Cycle and on Global Climate. Trans.-Am. Geophys. Union 1968, 49 (1), 183.

(23) Keeling, C. D. Is Carbon Dioxide from Fossil Fuel Changing Man's Environment? Proc. Am. Philos. Soc. 1970, 114 (1), 10-17.

(24) Keeling, C. D. A Chemist thinks about Future. Arch. Environ. Health 1970, 20 (6), 764-777.

(25) Fritts, H. C. An approach to dendroclimatology - screening by means of multiple regression techniques. J. Geophys. Res. 1962, 67 (4), $1413-1420$

(26) Fritts, H. C. Dendroclimatology and Dendroecology. Quat. Res. 1971, 1 (4), 419-449.

(27) Wigley, T. M. L.; Briffa, K. R.; Jones, P. D. On the average value of correlated time-series, with applications in dendroclimatology and hydrometeorology. J. Clim. Appl. Meteorol. 1984, 23 (2), 201-213.
(28) Galimov, E. M. Contribution of technogenic $\mathrm{CO}_{2}$ to balance of atmosphere carbon dioxide (study of C-13-C-12 in annual rings of trees). Dokl. Akad. Nauk SSSR 1975, 225 (1), 190-191.

(29) Wagener, K. Total anthropogenic $\mathrm{CO}_{2}$ production during period 1800-1935 from C-13 measurements in tree rings. Radiat. Environ. Biophys. 1978, 15 (2), 101-111.

(30) Jones, P. D.; Briffa, K. R.; Osborn, T. J.; Lough, J. M.; van Ommen, T. D.; Vinther, B. M.; Luterbacher, J.; Wahl, E. R.; Zwiers, F. W.; Mann, M. E.; Schmidt, G. A.; Ammann, C. M.; Buckley, B. M.; Cobb, K. M.; Esper, J.; Goosse, H.; Graham, N.; Jansen, E.; Kiefer, T.; Kull, C.; Kuttel, M.; Mosley-Thompson, E.; Overpeck, J. T.; Riedwyl, N.; Schulz, M.; Tudhope, A. W.; Villalba, R.; Wanner, H.; Wolff, E.; Xoplaki, E. High-resolution palaeoclimatology of the last millennium: a review of current status and future prospects. Holocene 2009, 19 (1), $3-49$.

(31) Shackleton, N. J.; Opdyke, N. D. Oxygen Isotope and Palaeomagnetic Stratigraphy of Equatorial Pacific Core V28-238: Oxygen Isotope Temperatures and Ice Volumes on a 105 Year and 106 Year Scale. Quat. Res. 1973, 3 (1), 39-55.

(32) Broecker, W. S. Glacial to interglacial changes in ocean chemistry. Prog. Oceanogr. 1982, 11 (2), 151-197.

(33) Dansgaard, W.; Clausen, H. B.; Gundestrup, N.; Hammer, C. U.; Johnsen, S. F.; Kristinsdottir, P. M.; Reeh, N. A New Greenland Deep Ice Core. Science 1982, 218 (4579), 1273-1277.

(34) Shackleton, N. J.; Hall, M. A.; Line, J.; Shuxi, C. Carbon isotope data in core V19-30 confirm reduced carbon dioxide concentration in the ice age atmosphere. Nature 1983, 306, 319.

(35) Lorius, C.; Jouzel, J.; Ritz, C.; Merlivat, L.; Barkov, N. I.; Korotkevich, Y. S.; Kotlyakov, V. M. A 150,000-year climatic record from Antarctic ice. Nature 1985, 316, 591.

(36) Pearson, P. N.; Palmer, M. R. Atmospheric carbon dioxide concentrations over the past 60 million years. Nature 2000, 406, 695 .

(37) Rich, N. Losing Earth: The Decade We Almost Stopped Climate Change. URL: https://www.nytimes.com/interactive/2018/ 08/01/magazine/climate-change-losing-earth.html (accessed September 2nd, 2018).

(38) Pillai, D.; Buchwitz, M.; Gerbig, C.; Koch, T.; Reuter, M.; Bovensmann, H.; Marshall, J.; Burrows, J. P. Tracking city $\mathrm{CO}_{2}$ emissions from space using a high-resolution inverse modelling approach: a case study for Berlin, Germany. Atmos. Chem. Phys. 2016, 16, 9591-9610.

(39) Pekel, J. F.; Cottam, A.; Gorelick, N.; Belward, A. S. Highresolution mapping of global surface water and its long-term changes. Nature 2016, 540 (7633), 418-422.

(40) Andela, N.; Morton, D. C.; Giglio, L.; Chen, Y.; van der Werf, G. R.; Kasibhatla, P. S.; DeFries, R. S.; Collatz, G. J.; Hantson, S.; Kloster, S.; Bachelet, D.; Forrest, M.; Lasslop, G.; Li, F.; Mangeon, S.; Melton, J. R.; Yue, C.; Randerson, J. T. A human-driven decline in global burned area. Science 2017, 356 (6345), 1356-1362.

(41) Morgenstern, O.; Hegglin, M. I.; Rozanov, E.; O’Connor, F. M.; Abraham, N. L.; Akiyoshi, H.; Archibald, A. T.; Bekki, S.; Butchart, N.; Chipperfield, M. P.; Deushi, M.; Dhomse, S. S.; Garcia, R. R.; Hardiman, S. C.; Horowitz, L. W.; Jockel, P.; Josse, B.; Kinnison, D.; Lin, M. Y.; Mancini, E.; Manyin, M. E.; Marchand, M.; Marecal, V.; Michou, M.; Oman, L. D.; Pitari, G.; Plummer, D. A.; Revell, L. E.; Saint-Martin, D.; Schofield, R.; Stenke, A.; Stone, K.; Sudo, K.; Tanaka, T. Y.; Tilmes, S.; Yamashita, Y.; Yoshida, K.; Zeng, G. Review of the global models used within phase 1 of the ChemistryClimate Model Initiative (CCMI). Geosci. Model Dev. 2017, 10 (2), 639-671.

(42) Cook, J.; Nuccitelli, D.; Green, S. A.; Richardson, M.; Winkler, B.; Painting, R.; Way, R.; Jacobs, P.; Skuce, A. Quantifying the consensus on anthropogenic global warming in the scientific literature. Environ. Res. Lett. 2013, 8 (2), 024024.

(43) Dunlap, R. E.; McCright, A. M. Organized Climate Change Denial. The Oxford Handbook of Climate Change and Society; Oxford University Press Inc.: New York, 2011.

(44) Björnberg, K. E.; Karlsson, M.; Gilek, M.; Hansson, S. O. Climate and environmental science denial: A review of the scientific 
literature published in 1990-2015. J. Cleaner Prod. 2017, 167, 229241.

(45) Martens, J. A.; Bogaerts, A.; De Kimpe, N.; Jacobs, P. A.; Marin, G. B.; Rabaey, K.; Saeys, M.; Verhelst, S. The Chemical Route to a Carbon Dioxide Neutral World. ChemSusChem 2017, 10 (6), 10391055 .

(46) Dutcher, B.; Fan, M. H.; Russell, A. G. Amine-Based $\mathrm{CO}_{2}$ Capture Technology Development from the Beginning of 2013-A Review. ACS Appl. Mater. Interfaces 2015, 7 (4), 2137-2148.

(47) Bernhardsen, I. M.; Knuutila, H. K. A review of potential amine solvents for $\mathrm{CO}_{2}$ absorption process: Absorption capacity, cyclic capacity and pKa. Int. J. Greenhouse Gas Control 2017, 61, 27-48.

(48) Hu, G. P.; Nicholas, N. J.; Smith, K. H.; Mumford, K. A.; Kentish, S. E.; Stevens, G. W. Carbon dioxide absorption into promoted potassium carbonate solutions: A review. Int. J. Greenhouse Gas Control 2016, 53, 28-40.

(49) Babamohammadi, S.; Shamiri, A.; Aroua, M. K. A review of $\mathrm{CO}_{2}$ capture by absorption in ionic liquid-based solvents. Rev. Chem. Eng. 2015, 31 (4), 383-412.

(50) Luo, X. Y.; Wang, C. M. The development of carbon capture by functionalized ionic liquids. Curr. Opin. Green Sustain. Chem. 2017, 3, $33-38$.

(51) Boot-Handford, M. E.; Abanades, J. C.; Anthony, E. J.; Blunt, M. J.; Brandani, S.; Mac Dowell, N.; Fernandez, J. R.; Ferrari, M.-C.; Gross, R.; Hallett, J. P.; Haszeldine, R. S.; Heptonstall, P.; Lyngfelt, A.; Makuch, Z.; Mangano, E.; Porter, R. T. J.; Pourkashanian, M.; Rochelle, G. T.; Shah, N.; Yao, J. G.; Fennell, P. S. Carbon capture and storage update. Energy Environ. Sci. 2014, 7 (1), 130-189.

(52) Ben-Mansour, R.; Habib, M. A.; Bamidele, O. E.; Basha, M.; Qasem, N. A. A.; Peedikakkal, A.; Laoui, T.; Ali, M. Carbon capture by physical adsorption: Materials, experimental investigations and numerical modeling and simulations - A review. Appl. Energy 2016, $161,225-255$.

(53) Abu Ghalia, M.; Dahman, Y. Development and Evaluation of Zeolites and Metal-Organic Frameworks for Carbon Dioxide Separation and Capture. Energy Technology 2017, 5 (3), 356-372.

(54) Bae, Y. S.; Snurr, R. Q. Development and Evaluation of Porous Materials for Carbon Dioxide Separation and Capture. Angew. Chem., Int. Ed. 2011, 50 (49), 11586-11596.

(55) Song, C. F.; Liu, Q. L.; Ji, N.; Deng, S.; Zhao, J.; Li, Y.; Song, Y. J.; Li, H. L. Alternative pathways for efficient $\mathrm{CO}_{2}$ capture by hybrid processes - a review. Renewable Sustainable Energy Rev. 2018, 82, 215231.

(56) Sreenivasulu, B.; Gayatri, D. V.; Sreedhar, I.; Raghavan, K. V. A journey into the process and engineering aspects of carbon capture technologies. Renewable Sustainable Energy Rev. 2015, 41, 1324-1350.

(57) Marchetti, C. On geoengineering and the $\mathrm{CO}_{2}$ problem. Clim. Change 1977, 1 (1), 59-68.

(58) Aminu, M. D.; Nabavi, S. A.; Rochelle, C. A.; Manovic, V. A review of developments in carbon dioxide storage. Appl. Energy 2017, 208, 1389-1419.

(59) Anderson, S. T. Risk, Liability, and Economic Issues with LongTerm $\mathrm{CO}_{2}$ Storage - A Review. Nat. Resour. Res. 2017, 26 (1), 89112.

(60) Beckman, E. J. Supercritical and near-critical $\mathrm{CO}_{2}$ in green chemical synthesis and processing. J. Supercrit. Fluids 2004, 28 (2-3), $121-191$.

(61) Djas, M.; Henczka, M. Reactive extraction of carboxylic acids using organic solvents and supercritical fluids: A review. Sep. Purif. Technol. 2018, 201, 106-119.

(62) Dias, A. L. B.; dos Santos, P.; Martinez, J. Supercritical $\mathrm{CO}_{2}$ technology applied to the production of flavor ester compounds through lipase-catalyzed reaction: A review. J. $\mathrm{CO}_{2}$ Utilization 2018, 23, 159-178.

(63) Knez, Z.; Cor, D.; Hrncic, M. K. Solubility of Solids in Sub- and Supercritical Fluids: A Review 2010-2017. J. Chem. Eng. Data 2018, 63 (4), 860-884.

(64) Wang, B.; Li, Y. Q.; Wu, N.; Lan, C. Q. $\mathrm{CO}_{2}$ bio-mitigation using microalgae. Appl. Microbiol. Biotechnol. 2008, 79 (5), 707-718.
(65) Suganya, T.; Varman, M.; Masjuki, H. H.; Renganathan, S. Macroalgae and microalgae as a potential source for commercial applications along with biofuels production: A biorefinery approach. Renewable Sustainable Energy Rev. 2016, 55, 909-941.

(66) Narron, R. H.; Kim, H.; Chang, H.-m.; Jameel, H.; Park, S. Biomass pretreatments capable of enabling lignin valorization in a biorefinery process. Curr. Opin. Biotechnol. 2016, 38, 39-46.

(67) Tuck, C. O.; Perez, E.; Horvath, I. T.; Sheldon, R. A.; Poliakoff, M. Valorization of Biomass: Deriving More Value from Waste. Science 2012, 337 (6095), 695-699.

(68) Ragauskas, A. J.; Beckham, G. T.; Biddy, M. J.; Chandra, R.; Chen, F.; Davis, M. F.; Davison, B. H.; Dixon, R. A.; Gilna, P.; Keller, M.; Langan, P.; Naskar, A. K.; Saddler, J. N.; Tschaplinski, T. J.; Tuskan, G. A.; Wyman, C. E. Lignin Valorization: Improving Lignin Processing in the Biorefinery. Science 2014, 344 (6185), 1246843.

(69) Song, C. Global challenges and strategies for control, conversion and utilization of $\mathrm{CO}_{2}$ for sustainable development involving energy, catalysis, adsorption and chemical processing. Catal. Today 2006, 115 (1-4), 2-32.

(70) Aresta, M.; Dibenedetto, A.; Angelini, A. The changing paradigm in $\mathrm{CO}_{2}$ utilization. $J$. $\mathrm{CO}_{2}$ Utilization 2013, 3-4, 65-73.

(71) Verbeeck, K.; Buelens, L. C.; Galvita, V. V.; Marin, G. B.; Van Geem, K. M.; Rabaey, K. Upgrading the value of anaerobic digestion via chemical production from grid injected biomethane. Energy Environ. Sci. 2018, 11 (7), 1788-1802.

(72) World Energy Resources; World Energy Council, 2016; pp 11028

(73) Boulamanti, A.; Moya, J. A. Production costs of the chemical industry in the EU and other countries: Ammonia, methanol and light olefins. Renewable Sustainable Energy Rev. 2017, 68, 1205-1212.

(74) Tian, P.; Wei, Y. X.; Ye, M.; Liu, Z. M. Methanol to Olefins (MTO): From Fundamentals to Commercialization. ACS Catal. 2015, 5 (3), 1922-1938.

(75) Canilha, L.; Rodrigues, R. d. C. L. B.; Antunes, F. A. F.; Chandel, A. K.; Milessi, T. S. d. S.; Felipe, M. d. G. A.; Silva, S. S. d., Bioconversion of Hemicellulose from Sugarcane Biomass Into Sustainable Products. In Sustainable Degradation of Lignocellulosic Biomass - Techniques, Applications and Commercialization; Chandel, A. K., Silva, S. S. d., Eds.; InTech: Rijeka, 2013; Chapter 2.

(76) Bahmanpour, A. M.; Hoadley, A.; Mushrif, S. H.; Tanksale, A. Hydrogenation of Carbon Monoxide into Formaldehyde in Liquid Media. ACS Sustainable Chem. Eng. 2016, 4 (7), 3970-3977.

(77) Yang, S.-T.; El-Ensashy, H.; Thongchul, N. Bioprocessing Technologies in Biorefinery for Sustainable Production of Fuels, Chemicals, and Polymers; John Wiley \& Sons: Hoboken, NJ, 2013; p 488.

(78) Jakobsson, N. B.; Hinnemann, B.; Pedersen, F. C.; Schjødt, N. C. A process for safe production of phosgene. WO2015189064 A1, December 17th, 2015, 2015.

(79) Eckert, M.; Fleischmann, G.; Jira, R.; Bolt, H. M.; Golka, K., Acetaldehyde. In Ullmann's Encyclopedia of Industrial Chemistry; Wiley-VCH Verlag GmbH \& Co. KGaA: 2006.

(80) Araújo, O. d. Q. F.; Medeiros, J. L. d.; Alves, R. M. B., $\mathrm{CO}_{2}$ Utilization: A Process Systems Engineering Vision. In $\mathrm{CO}_{2}$ Sequestration and Valorization, Morgado, C. d. R. V., Esteves, V. P. P., Eds.; InTech: Rijeka, 2014; p Ch. 02.

(81) Mahoutian, M.; Shao, Y. X. Production of cement-free construction blocks from industry wastes. J. Cleaner Prod. 2016, 137, 1339-1346.

(82) Mahoutian, M.; Ghouleh, Z.; Shao, Y. X. Synthesis of wastebased carbonation cement. Mater. Struct. 2016, 49 (11), 4679-4690.

(83) Mahoutian, M.; Chaallal, O.; Shao, Y. X. Pilot production of steel slag masonry blocks. Can. J. Civ. Eng. 2018, 45 (7), 537-546.

(84) Hoppe-Seyler, F., Beiträge zur Kenntniss der Constitution des Blutes: 1. Über die Oxydation im lebendem Blute. In Medicinischchemische Untersuchungen, Laboratorium für angewandte Chemie, Tübingen; Verlag von August Hirschwald, 1866; Vol. 1, pp 133-140.

(85) Hepworth, T. C. Oxygen for Limelight. Nature 1892, 47 (1208), 176-177. 
(86) Zeng, L.; Cheng, Z.; Fan, J. A.; Fan, L.-S.; Gong, J. Metal oxide redox chemistry for chemical looping processes. Nature Reviews Chemistry 2018, 2 (11), 349-364.

(87) Bergmann, F. J. Process for the Production of Calcium Carbide in Blast Furnaces. GB189729384A, December 11th, 1897, 1897.

(88) Messerschmitt, A. Process of producing hydrogen. US971206A, 2 december 1908, 1910.

(89) Dickinson, N. L. Treatment of solid carbon containing materials to produce carbon monoxide for the synthesis of organic materials. US2602809A, July 10th 1948, 1952.

(90) Jones, M. C. K. Production of mixture of carbon monoxide and hydrogen. US2640034A, June 4th 1946, 1953.

(91) Lewis, W. K.; Gilliland, E. R. Production of pure carbon dioxide. US2665972A, November 13th 1950, 1954.

(92) Funk, J. E.; Reinstrom, R. M. Energy Requirements in Production of Hydrogen from Water. Ind. Eng. Chem. Process Des. Dev. 1966, 5 (3), 336-342.

(93) Schulten, R.; Knoche, K. F. Hydrogen and oxygen thermally produced from water - by reacting ferric oxide with sulphur dioxide and steam in 3 stages at increased temperature and elevated pressure. DE2260599A1, December 9th, 1972.

(94) Soliman, M. A.; Conger, W. L.; Carty, R. H.; Funk, J. E.; Cox, K. E. Hydrogen production via thermochemical cycles based on sulfur chemistry. Int. J. Hydrogen Energy 1976, 1 (3), 265-270.

(95) Ota, K.; Conger, W. L. Thermochemical hydrogen production via a cycle using barium and sulfur: Reaction between barium sulfide and water. Int. J. Hydrogen Energy 1977, 2 (2), 101-106.

(96) Kameyama, H.; Yoshida, K.; Kunii, D. A method for screening possible thermochemical decomposition processes for water using $\Delta \mathrm{G0}$-T diagrams. Chemical Engineering Journal 1976, 11 (3), 223229.

(97) Richter, H. J.; Knoche, K. F. Reversibility of combustion processes, in Efficiency and Costing - Second law analysis of processes. ACS Symp. Ser. 1983, 235, 71-85.

(98) Ishida, M.; Zheng, D.; Akehata, T. Evaluation of a chemicallooping-combustion power-generation system by graphic exergy analysis. Energy 1987, 12 (2), 147-154.

(99) Ishida, M.; Jin, H. A novel combustor based on chemicallooping reactions and its reaction kinetics. J. Chem. Eng. Jpn. 1994, 27 (3), 296-301.

(100) Ishida, M.; Jin, H. G. A new advanced power-generation system using chemical-looping combustion. Energy 1994, 19 (4), 415-422.

(101) Ishida, M.; Jin, H. Chemical-looping combustion power generation plant system. US5447024A, November 7th 1994, 1995.

(102) Ishida, M.; Jin, H. G. A novel chemical-looping combustor without NOx formation. Ind. Eng. Chem. Res. 1996, 35 (7), 24692472

(103) Van Looij, F. Catalytic Partial Oxidation of Methane to Synthesis Gas. Doctoral dissertation, Utrecht University, Utrecht, 1994. (104) Stobbe, E. R.; de Boer, B. A.; Geus, J. W. The reduction and oxidation behaviour of manganese oxides. Catal. Today 1999, 47 (1), 161-167.

(105) Mattisson, T.; Lyngfelt, A. Applications of chemical-looping combustion with capture of $\mathrm{CO}_{2}$. Second Nordic Minisymposium on $\mathrm{CO}_{2}$ Capture and Storage; Center for Environment and Sustainability: Chalmers, 2002; pp 46-51.

(106) Rydén, M.; Lyngfelt, A., Hydrogen and power production with integrated carbon dioxide capture by chemical-looping reforming. In Greenhouse Gas Control Technologies 7; Elsevier Science Ltd.: Oxford, 2005; pp 125-134.

(107) Zafar, Q.; Mattisson, T.; Gevert, B. Integrated Hydrogen and Power Production with $\mathrm{CO}_{2}$ Capture Using Chemical-Looping Reforming Redox Reactivity of Particles of $\mathrm{CuO}, \mathrm{Mn}_{2} \mathrm{O}_{3}, \mathrm{NiO}$, and $\mathrm{Fe}_{2} \mathrm{O}_{3}$ Using $\mathrm{SiO}_{2}$ as a Support. Ind. Eng. Chem. Res. 2005, 44 (10), 3485-3496.

(108) Hong, H.; Jin, H. G.; Liu, B. Q. A novel solar-hybrid gas turbine combined cycle with inherent $\mathrm{CO}_{2}$ separation using chemical- looping combustion by solar heat source. J. Sol. Energy Eng. 2006, 128 (3), 275-284

(109) Rydén, M.; Lyngfelt, A.; Mattisson, T. Synthesis gas generation by chemical-looping reforming in a continuously operating laboratory reactor. Fuel 2006, 85 (12), 1631-1641.

(110) Chiesa, P.; Lozza, G.; Malandrino, A.; Romano, M.; Piccolo, V. Three-reactors chemical looping process for hydrogen production. Int. J. Hydrogen Energy 2008, 33 (9), 2233-2245.

(111) Gupta, P.; Velazquez-Vargas, L. G.; Fan, L.-S. Syngas Redox (SGR) Process to Produce Hydrogen from Coal Derived Syngas. Energy Fuels 2007, 21 (5), 2900-2908.

(112) Ortiz, M.; de Diego, L. F.; Abad, A.; Garcia-Labiano, F.; Gayan, P.; Adanez, J. Hydrogen production by auto-thermal chemicallooping reforming in a pressurized fluidized bed reactor using $\mathrm{Ni}$ based oxygen carriers. Int. J. Hydrogen Energy 2010, 35 (1), 151-160.

(113) Galvita, V.; Sundmacher, K. Hydrogen production from methane by steam reforming in a periodically operated two-layer catalytic reactor. Appl. Catal., A 2005, 289 (2), 121-127.

(114) Galvita, V. V.; Poelman, H.; Marin, G. B. Hydrogen Production from Methane and Carbon Dioxide by Catalyst-Assisted Chemical Looping. Top. Catal. 2011, 54 (13-15), 907-913.

(115) Mattisson, T.; Lyngfelt, A.; Leion, H. Chemical-looping with oxygen uncoupling for combustion of solid fuels. Int. J. Greenhouse Gas Control 2009, 3 (1), 11-19.

(116) Mattisson, T.; Leion, H.; Lyngfelt, A. Chemical-looping with oxygen uncoupling using $\mathrm{CuO} / \mathrm{ZrO}_{2}$ with petroleum coke. Fuel 2009, 88 (4), 683-690.

(117) Najera, M.; Solunke, R. D.; Gardner, T.; Veser, G. Catalytic $\mathrm{CO}_{2}$ reduction via chemical looping dry reforming. Abstr. Pap. Am. Chem. Soc. 2010, 239, 1.

(118) Najera, M.; Solunke, R.; Gardner, T.; Veser, G. Carbon capture and utilization via chemical looping dry reforming. Chem. Eng. Res. Des. 2011, 89 (9), 1533-1543.

(119) Bhavsar, S.; Najera, M.; Veser, G. Chemical Looping Dry Reforming as Novel, Intensified Process for $\mathrm{CO}_{2}$ Activation. Chem. Eng. Technol. 2012, 35 (7), 1281-1290.

(120) Bhavsar, S.; Najera, M.; Solunke, R.; Veser, G. Chemical looping: To combustion and beyond. Catal. Today 2014, 228, 96105.

(121) Galvita, V. V.; Poelman, H.; Detavernier, C.; Marin, G. B. Catalyst-assisted chemical looping for $\mathrm{CO}_{2}$ conversion to CO. Appl. Catal., B 2015, 164, 184-191.

(122) Hu, J.; Buelens, L.; Theofanidis, S.-A.; Galvita, V. V.; Poelman, H.; Marin, G. B. $\mathrm{CO}_{2}$ conversion to $\mathrm{CO}$ by auto-thermal catalystassisted chemical looping. J. $\mathrm{CO}_{2}$ Utilization 2016, 16, 8-16.

(123) Dharanipragada, N. V. R. A.; Galvita, V. V.; Poelman, H.; Buelens, L. C.; Detavernier, C.; Marin, G. B. Bifunctional Co- and Niferrites for catalyst-assisted chemical looping with alcohols. Appl. Catal., B 2018, 222, 59-72.

(124) Hu, J.; Galvita, V. V.; Poelman, H.; Marin, G. B. Advanced Chemical Looping Materials for CO2 Utilization: A Review. Materials 2018, 11 (7), 1187.

(125) Fan, L.-S.; Li, F. Chemical Looping Technology and Its Fossil Energy Conversion Applications. Ind. Eng. Chem. Res. 2010, 49 (21), 10200-10211.

(126) Fan, L. S. Chemical Looping Systems for Fossil Energy Conversions; Wiley: Hoboken, NJ, 2010.

(127) Adanez, J.; Abad, A.; Garcia-Labiano, F.; Gayan, P.; de Diego, L. F. Progress in Chemical-Looping Combustion and Reforming technologies. Prog. Energy Combust. Sci. 2012, 38 (2), 215-282.

(128) Fan, L.-S.; Zeng, L.; Wang, W.; Luo, S. Chemical looping processes for $\mathrm{CO}_{2}$ capture and carbonaceous fuel conversion prospect and opportunity. Energy Environ. Sci. 2012, 5 (6), 72547280 .

(129) Fan, L. S.; Zeng, L.; Luo, S. W. Chemical-Looping Technology Platform. AIChE J. 2015, 61 (1), 2-22.

(130) Nandy, A.; Loha, C.; Gu, S.; Sarkar, P.; Karmakar, M. K.; Chatterjee, P. K. Present status and overview of Chemical Looping 
Combustion technology. Renewable Sustainable Energy Rev. 2016, 59, 597-619.

(131) Zhao, X.; Zhou, H.; Sikarwar, V. S.; Zhao, M.; Park, A.-H. A.; Fennell, P. S.; Shen, L.; Fan, L.-S. Biomass-based chemical looping technologies: the good, the bad and the future. Energy Environ. Sci. 2017, 10 (9), 1885-1910.

(132) Luo, M.; Yi, Y.; Wang, S. Z.; Wang, Z. L.; Du, M.; Pan, J. F.; Wang, Q. Review of hydrogen production using chemical-looping technology. Renewable Sustainable Energy Rev. 2018, 81, 3186-3214.

(133) Scheffe, J. R.; Steinfeld, A. Oxygen exchange materials for solar thermochemical splitting of $\mathrm{H}_{2} \mathrm{O}$ and $\mathrm{CO}_{2}$ : a review. Mater. Today 2014, 17 (7), 341-348.

(134) Agrafiotis, C.; Roeb, M.; Sattler, C. A review on solar thermal syngas production via redox pair-based water/carbon dioxide splitting thermochemical cycles. Renewable Sustainable Energy Rev. 2015, 42, 254-285.

(135) Block, T.; Schmücker, M. Metal oxides for thermochemical energy storage: A comparison of several metal oxide systems. Sol. Energy 2016, 126, 195-207.

(136) Voitic, G.; Hacker, V. Recent advancements in chemical looping water splitting for the production of hydrogen. RSC $A d v$. 2016, 6 (100), 98267-98296.

(137) Al-Shankiti, I.; Ehrhart, B. D.; Weimer, A. W. Isothermal redox for $\mathrm{H}_{2} \mathrm{O}$ and $\mathrm{CO}_{2}$ splitting - A review and perspective. Sol. Energy 2017, 156, 21-29.

(138) Gluud, W.; Keller, K.; Schonfelder, R.; Klempt, W. Production of hydrogen. US1816523A, July 28th, 1931, 1931.

(139) Everett, G. Synthetic $\mathrm{CO}_{2}$ acceptor and gasification process therewith. US4191538A, March 4th, 19801980.

(140) Brun-Tsekhovoi, A. R.; Zadorin, A. N.; Katsobashvili, Y. R.; Kourdyumov, S. S., The process of catalytic steam-reforming of hydrocarbons in the presence of carbon dioxide acceptor. In Hydrogen energy progress, VII. Proceedings of the 7th World Hydrogen Energy Conference; Pergamon Press: New York, 1988; pp 885-900.

(141) Han, C.; Harrison, D. P. Simultaneous shift reaction and carbon dioxide separation for the direct production of hydrogen. Chem. Eng. Sci. 1994, 49, 5875-5883.

(142) Silaban, A.; Harrison, D. P. High temperature capture of carbon dioxide: Characteristics of the reversible reaction between $\mathrm{CaO}(\mathrm{s})$ and $\mathrm{CO}_{2}(\mathrm{~g})$. Chem. Eng. Commun. 1995, 137 (1), 177-190.

(143) Silaban, A.; Narcida, M.; Harrison, D. P. Characteristics of the reversible reaction between $\mathrm{CO}_{2}(\mathrm{~g})$ and calcined dolomite. Chem. Eng. Commun. 1996, 146 (1), 149-162.

(144) Nakagawa, K.; Ohashi, T. A novel method of $\mathrm{CO}_{2}$ capture from high temperature gases. J. Electrochem. Soc. 1998, 145 (4), 1344-1346.

(145) Shimizu, T.; Hirama, T.; Hosoda, H.; Kitano, K.; Inagaki, M.; Tejima, K. A twin fluid-bed reactor for removal of $\mathrm{CO}_{2}$ from combustion processes. Chem. Eng. Res. Des. 1999, 77 (A1), 62-68.

(146) Lyon, R. K. Methods and systems for heat transfer by unmixed combustion. WO1996033794A1, October 31st, 1996, 1996.

(147) Kumar, R. V.; Lyon, R. K.; Cole, J. A. Unmixed Reforming: A Novel Autothermal Cyclic Steam Reforming Process. In Advances in Hydrogen Energy; Grégoire Padró, C. E., Lau, F., Eds; Springer: Boston, MA, 2002.

(148) Lyon, R. K.; Cole, J. A. Unmixed combustion: an alternative to fire. Combust. Flame 2000, 121 (1), 249-261.

(149) Dupont, V.; Ross, A. B.; Hanley, I.; Twigg, M. V. Unmixed steam reforming of methane and sunflower oil: A single-reactor process for $\mathrm{H}_{2}$-rich gas. Int. J. Hydrogen Energy 2007, 32 (1), 67-79.

(150) Dupont, V.; Ross, A. B.; Knight, E.; Hanley, I.; Twigg, M. V. Production of hydrogen by unmixed steam reforming of methane. Chem. Eng. Sci. 2008, 63 (11), 2966-2979.

(151) Chen, H.; Zhang, T.; Dou, B.; Dupont, V.; Williams, P.; Ghadiri, M.; Ding, Y. Thermodynamic analyses of adsorptionenhanced steam reforming of glycerol for hydrogen production. Int. J. Hydrogen Energy 2009, 34 (17), 7208-7222.

(152) Pimenidou, P.; Rickett, G.; Dupont, V.; Twigg, M. V. High purity $\mathrm{H}_{2}$ by sorption-enhanced chemical looping reforming of waste cooking oil in a packed bed reactor. Bioresour. Technol. 2010, 101 (23), 9279-9286.

(153) Pimenidou, P.; Dupont, V. Dolomite study for in situ $\mathrm{CO}_{2}$ capture for chemical looping reforming. Int. J. Ambient Energy 2015, 36 (4), 170-182.

(154) Adiya, Z. I. S. G.; Dupont, V.; Mahmud, T. Chemical equilibrium analysis of hydrogen production from shale gas using sorption enhanced chemical looping steam reforming. Fuel Process. Technol. 2017, 159, 128-144.

(155) Abbas, S. Z.; Dupont, V.; Mahmud, T. Modelling of $\mathrm{H}_{2}$ production in a packed bed reactor via sorption enhanced steam methane reforming process. Int. J. Hydrogen Energy 2017, 42 (30), 18910-18921.

(156) Abbas, S. Z.; Dupont, V.; Mahmud, T. Modelling of high purity $\mathrm{H}_{2}$ production via sorption enhanced chemical looping steam reforming of methane in a packed bed reactor. Fuel 2017, 202, 271286.

(157) Abanades, J. C.; Murillo, R.; Fernandez, J. R.; Grasa, G.; Martinez, I. New $\mathrm{CO}_{2}$ Capture Process for Hydrogen Production Combining $\mathrm{Ca}$ and $\mathrm{Cu}$ Chemical Loops. Environ. Sci. Technol. 2010, 44 (17), 6901-6904.

(158) Galvita, V. V.; Poelman, H.; Marin, G. B. Combined chemical looping for energy storage and conversion. J. Power Sources 2015, 286, $362-370$.

(159) Buelens, L. C.; Galvita, V. V.; Poelman, H.; Detavernier, C.; Marin, G. B. Super-dry reforming of methane intensifies $\mathrm{CO}_{2}$ utilization via Le Chatelier's principle. Science 2016, 354 (6311), 449-452.

(160) Kim, S. M.; Abdala, P. M.; Broda, M.; Hosseini, D.; Copéret, C.; Müller, C. Integrated CO2 Capture and Conversion as an Efficient Process for Fuels from Greenhouse Gases. ACS Catal. 2018, 8 (4), 2815-2823

(161) Mattisson, T.; Jardnas, A.; Lyngfelt, A. Reactivity of some metal oxides supported on alumina with alternating methane and oxygen-application for chemical-looping combustion. Energy Fuels 2003, 17 (3), 643-651.

(162) Adánez, J.; de Diego, L. F.; García-Labiano, F.; Gayán, P.; Abad, A.; Palacios, J. M. Selection of Oxygen Carriers for ChemicalLooping Combustion. Energy Fuels 2004, 18 (2), 371-377.

(163) Cho, P.; Mattisson, T.; Lyngfelt, A. Comparison of iron-, nickel-, copper- and manganese-based oxygen carriers for chemicallooping combustion. Fuel 2004, 83 (9), 1215-1225.

(164) Zafar, Q.; Mattisson, T.; Gevert, B. Redox Investigation of Some Oxides of Transition-State Metals $\mathrm{Ni}, \mathrm{Cu}, \mathrm{Fe}$, and $\mathrm{Mn}$ Supported on $\mathrm{SiO}_{2}$ and $\mathrm{MgAl}_{2} \mathrm{O}_{4}$. Energy Fuels 2006, 20 (1), 34-44. (165) Remsen, S.; Dabrowski, B. Synthesis and Oxygen Storage Capacities of Hexagonal $\mathrm{Dy}_{1-\mathrm{x}} \mathrm{Y}_{\mathrm{x}} \mathrm{MnO}_{3+\delta}$. Chem. Mater. 2011, 23 (17), $3818-3827$.

(166) Rydén, M.; Lyngfelt, A.; Mattisson, T. $\mathrm{CaMn}_{0.875} \mathrm{Ti}_{0.125} \mathrm{O}_{3}$ as oxygen carrier for chemical-looping combustion with oxygen uncoupling (CLOU)-Experiments in a continuously operating fluidized-bed reactor system. Int. J. Greenhouse Gas Control 2011, 5 (2), 356-366.

(167) Jin, H. G.; Okamoto, T.; Ishida, M. Development of a novel chemical-looping combustion: Synthesis of a looping material with a double metal oxide of CoO-NiO. Energy Fuels 1998, 12 (6), 12721277.

(168) Jin, H. G.; Okamoto, T.; Ishida, M. Development of a novel chemical-looping combustion: Synthesis of a solid looping material of $\mathrm{NiO} / \mathrm{NiAl}_{2} \mathrm{O}_{4}$. Ind. Eng. Chem. Res. 1999, 38 (1), 126-132.

(169) Mattisson, T.; Lyngfelt, A.; Cho, P. The use of iron oxide as an oxygen carrier in chemical-looping combustion of methane with inherent separation of $\mathrm{CO}_{2}$. Fuel 2001, 80 (13), 1953-1962.

(170) Johansson, M.; Mattisson, T.; Lyngfelt, A. Investigation of $\mathrm{Fe}_{2} \mathrm{O}_{3}$ with $\mathrm{MgAl}_{2} \mathrm{O}_{4}$ for Chemical-Looping Combustion. Ind. Eng. Chem. Res. 2004, 43 (22), 6978-6987.

(171) Galvita, V.; Hempel, T.; Lorenz, H.; Rihko-Struckmann, L. K.; Sundmacher, K. Deactivation of Modified Iron Oxide Materials in the 
Cyclic Water Gas Shift Process for CO-Free Hydrogen Production. Ind. Eng. Chem. Res. 2008, 47 (2), 303-310.

(172) Galvita, V.; Sundmacher, K. Cyclic water gas shift reactor (CWGS) for carbon monoxide removal from hydrogen feed gas for PEM fuel cells. Chem. Eng. J. 2007, 134 (1-3), 168-174.

(173) Rydén, M.; Lyngfelt, A.; Mattisson, T.; Chen, D.; Holmen, A.; Bjørgum, E. Novel oxygen-carrier materials for chemical-looping combustion and chemical-looping reforming; $\mathrm{La}_{x} \mathrm{Sr}_{1-\mathrm{x}} \mathrm{Fe}_{\mathrm{y}} \mathrm{Co}_{1-\mathrm{y}} \mathrm{O}_{3-\delta}$ perovskites and mixed-metal oxides of $\mathrm{NiO}, \mathrm{Fe}_{2} \mathrm{O}_{3}$ and $\mathrm{Mn}_{3} \mathrm{O}_{4}$. Int. J. Greenhouse Gas Control 2008, 2 (1), 21-36.

(174) Murugan, A.; Thursfield, A.; Metcalfe, I. S. A chemical looping process for hydrogen production using iron-containing perovskites. Energy Environ. Sci. 2011, 4 (11), 4639-4649.

(175) Galvita, V. V.; Poelman, H.; Bliznuk, V.; Detavernier, C.; Marin, G. B. $\mathrm{CeO}_{2}$-Modified $\mathrm{Fe}_{2} \mathrm{O}_{3}$ for $\mathrm{CO}_{2}$ Utilization via Chemical Looping. Ind. Eng. Chem. Res. 2013, 52 (25), 8416-8426.

(176) Dharanipragada, N. V. R. A.; Buelens, L. C.; Poelman, H.; De Grave, E.; Galvita, V. V.; Marin, G. B. Mg-Fe-Al-O for advanced $\mathrm{CO}_{2}$ to $\mathrm{CO}$ conversion: carbon monoxide yield vs. oxygen storage capacity. J. Mater. Chem. A 2015, 3 (31), 16251-16262.

(177) Villa, R.; Cristiani, C.; Groppi, G.; Lietti, L.; Forzatti, P.; Cornaro, U.; Rossini, S. Ni based mixed oxide materials for $\mathrm{CH}_{4}$ oxidation under redox cycle conditions. J. Mol. Catal. A: Chem. 2003, 204, 637-646.

(178) Go, K. S.; Son, S. R.; Kim, S. D. Reaction kinetics of reduction and oxidation of metal oxides for hydrogen production. Int. J. Hydrogen Energy 2008, 33 (21), 5986-5995.

(179) Chiron, F.-X.; Patience, G. S. Kinetics of mixed copper-iron based oxygen carriers for hydrogen production by chemical looping water splitting. Int. J. Hydrogen Energy 2012, 37 (14), 10526-10538.

(180) Dharanipragada, N. V. R. A. $\mathrm{CO}_{2}$ Utilization by Chemical Looping: Iron Oxides Characterization by In Situ XRD and XAS. Doctoral dissertation, Ghent University, Ghent, 2017.

(181) Bale, C.; Chartrand, P.; Degterov, S. A.; Eriksson, G.; Hack, K.; Ben Mahfoud, R.; Melancon, J.; Pelton, A. D.; Petersen, S. FactSage thermochemical software and databases. CALPHAD: Comput. Coupling Phase Diagrams Thermochem. 2002, 26, 189-228.

(182) Bale, C. W.; Belisle, E.; Chartrand, P.; Decterov, S. A.; Eriksson, G.; Gheribi, A. E.; Hack, K.; Jung, I. H.; Kang, Y. B.; Melancon, J.; Pelton, A. D.; Petersen, S.; Robelin, C.; Sangster, J.; Spencer, P.; Van Ende, M. A. FactSage thermochemical software and databases. CALPHAD: Comput. Coupling Phase Diagrams Thermochem. 2016, 54, 35-53.

(183) Johansson, M.; Mattisson, T.; Lyngfelt, A. Comparison of oxygen carriers for chemical-looping combustion. Thermal Science 2006, 10 (3), 93-107.

(184) Lyngfelt, A. Oxygen carriers for chemical looping combustion - 4000 h of operational experience. Oil Gas Sci. Technol. 2011, 66 (2), $161-172$.

(185) Tang, M.; Xu, L.; Fan, M. Progress in oxygen carrier development of methane-based chemical-looping reforming: A review. Appl. Energy 2015, 151, 143-156.

(186) Protasova, L.; Snijkers, F. Recent developments in oxygen carrier materials for hydrogen production via chemical looping processes. Fuel 2016, 181, 75-93.

(187) Ishida, M.; Jin, H. G.; Okamoto, T. Kinetic behavior of solid particle in chemical-looping combustion: Suppressing carbon deposition in reduction. Energy Fuels 1998, 12 (2), 223-229.

(188) Ryu, H.-J.; Bae, D.-H.; Han, K.-H.; Lee, S.-Y.; Jin, G.-T.; Choi, J.-H. Oxidation and reduction characteristics of oxygen carrier particles and reaction kinetics by unreacted core model. Korean J. Chem. Eng. 2001, 18 (6), 831-837.

(189) Dharanipragada, N. V. R. A.; Meledina, M.; Galvita, V. V.; Poelman, H.; Turner, S.; Van Tendeloo, G.; Detavernier, C.; Marin, G. B. Deactivation Study of $\mathrm{Fe}_{2} \mathrm{O}_{3}-\mathrm{CeO}_{2}$ during Redox Cycles for $\mathrm{CO}$ Production from $\mathrm{CO}_{2}$. Ind. Eng. Chem. Res. 2016, 55 (20), 59115922.
(190) Sarshar, Z.; Kaliaguine, S. Reduction Kinetics of PerovskiteBased Oxygen Carriers for Chemical Looping Combustion. Ind. Eng. Chem. Res. 2013, 52 (21), 6946-6955.

(191) Thoreton, V.; Pishahang, M.; Mokkelbost, T.; Wiik, K.; Larring, Y. Microstructural Stability of Tailored $\mathrm{CaMn}_{0.875-\mathrm{x}} \mathrm{Fe}_{\mathrm{x}} \mathrm{Ti}_{0.125} \mathrm{O}_{3-\delta}$ Perovskite Oxygen Carrier Materials for Chemical Looping Combustion. Energy Technology 2017, 5 (9), $1579-1587$.

(192) Buelens, L. C.; Dharanipragada, A. N. V. R.; Poelman, H.; Zhou, Z.; Marin, G. B.; Galvita, V. V. Exploring the stability of $\mathrm{Fe}_{2} \mathrm{O}_{3^{-}}$ $\mathrm{MgAl}_{2} \mathrm{O}_{4}$ oxygen storage materials for $\mathrm{CO}$ production from $\mathrm{CO}_{2}$. J. $\mathrm{CO}_{2}$ Utilization 2019, 29, 36-45.

(193) Buelens, L. C.; Van Alboom, A.; Poelman, H.; Detavernier, C.; Marin, G. B.; Galvita, V. V. $\mathrm{Fe}_{2} \mathrm{O}_{3}-\mathrm{MgAl}_{2} \mathrm{O}_{4}$ for $\mathrm{CO}$ production from $\mathrm{CO}_{2}$ : Mössbauer spectroscopy and in situ X-ray diffraction. ACS Sustainable Chem. Eng. 2019, 7, 9553-9565.

(194) Hu, J.; Galvita, V. V.; Poelman, H.; Detavernier, C.; Marin, G. B. A core-shell structured $\mathrm{Fe}_{2} \mathrm{O}_{3} / \mathrm{ZrO}_{2} @ \mathrm{ZrO}_{2}$ nanomaterial with enhanced redox activity and stability for $\mathrm{CO}_{2}$ conversion. J. $\mathrm{CO}_{2}$ Utilization 2017, 17, 20-31.

(195) Hu, J.; Galvita, V. V.; Poelman, H.; Detavernier, C.; Marin, G. B. Catalyst-assisted chemical looping auto-thermal dry reforming: Spatial structuring effects on process efficiency. Appl. Catal., B 2018, 231, 123-136.

(196) Nakagawa, K.; Ohashi, T. High temperature $\mathrm{CO}_{2}$ absorption using lithium zirconate powder; Electrochemical Society Inc.: Pennington, 1998; Vol. 98, pp 370-376.

(197) Ohashi, T.; Nakagawa, K., Effect of potassium carbonate additive on $\mathrm{CO}_{2}$ absorption in lithium zirconate powder. In Symposium on Solid-State Chemistry of Inorganic Materials II; Kauzlarich, S. M., McCarron, E. M., Sleight, A. W., Zurloye, H. C., Eds.; Materials Research Society: Boston, 1999; Vol. 547, pp 249254.

(198) Essaki, K.; Nakagawa, K.; Kato, M. Acceleration effect of ternary carbonate on $\mathrm{CO}_{2}$ absorption rate in lithium zirconate powder. Nippon Seramikkusu Kyokai Gakujutsu Ronbunshi 2001, 109 (10), 829-833.

(199) Kato, M.; Nakagawa, K. New series of lithium containing complex oxides, lithium silicates, for application as a high temperature $\mathrm{CO}_{2}$ absorbent. Nippon Seramikkusu Kyokai Gakujutsu Ronbunshi 2001, 109 (11), 911-914.

(200) Kato, M.; Yoshikawa, S.; Nakagawa, K. Carbon dioxide absorption by lithium orthosilicate in a wide range of temperature and carbon dioxide concentrations. J. Mater. Sci. Lett. 2002, 21 (6), 485487.

(201) Zhang, S.; Zhang, Q.; Wang, H.; Ni, Y.; Zhu, Z. Absorption behaviors study on doped $\mathrm{Li}_{4} \mathrm{SiO}_{4}$ under a humidified atmosphere with low $\mathrm{CO}_{2}$ concentration. Int. J. Hydrogen Energy 2014, 39 (31), 17913-17920.

(202) Seggiani, M.; Stefanelli, E.; Puccini, M.; Vitolo, S. $\mathrm{CO}_{2}$ sorption/desorption performance study on $\mathrm{K}_{2} \mathrm{CO}_{3}$-doped $\mathrm{Li}_{4} \mathrm{SiO}_{4}$ based pellets. Chem. Eng. J. 2018, 339, 51-60.

(203) Yang, X.; Liu, W.; Sun, J.; Hu, Y.; Wang, W.; Chen, H.; Zhang, Y.; Li, X.; Xu, M. Alkali-Doped Lithium Orthosilicate Sorbents for Carbon Dioxide Capture. ChemSusChem 2016, 9 (17), 2480-2487.

(204) Seggiani, M.; Puccini, M.; Vitolo, S. Alkali promoted lithium orthosilicate for $\mathrm{CO}_{2}$ capture at high temperature and low concentration. Int. J. Greenhouse Gas Control 2013, 17, 25-31.

(205) Mejía-Trejo, V. L.; Fregoso-Israel, E.; Pfeiffer, H. Textural, Structural, and $\mathrm{CO}_{2}$ Chemisorption Effects Produced on the Lithium Orthosilicate by Its Doping with Sodium $\left(\mathrm{Li}_{4-\mathrm{x}} \mathrm{Na}_{\mathrm{x}} \mathrm{SiO}_{4}\right)$. Chem. Mater. 2008, 20 (22), 7171-7176.

(206) Kato, M.; Nakagawa, K.; Essaki, K.; Maezawa, Y.; Takeda, S.; Kogo, R.; Hagiwara, Y. Novel $\mathrm{CO}_{2}$ Absorbents Using LithiumContaining Oxide. Int. J. Appl. Ceram. Technol. 2005, 2 (6), 467-475. (207) Kato, M.; Essaki, K.; Nakagawa, K.; Suyama, Y.; Terasaka, K. $\mathrm{CO}_{2}$ absorption properties of lithium ferrite for application as a hightemperature $\mathrm{CO}_{2}$ absorbent. Journal of the Ceramic Society of Japan 2005, 113 (1322), 684-686. 
(208) Ortiz-Landeros, J.; Romero-Ibarra, I. C.; Gómez-Yáñez, C.; Lima, E.; Pfeiffer, H. $\mathrm{Li}_{4+\mathrm{x}}\left(\mathrm{Si}_{1-\mathrm{x}} \mathrm{Al}_{\mathrm{x}}\right) \mathrm{O}_{4}$ Solid Solution Mechanosynthesis and Kinetic Analysis of the $\mathrm{CO}_{2}$ Chemisorption Process. J. Phys. Chem. C 2013, 117 (12), 6303-6311.

(209) Lee, S. C.; Choi, B. Y.; Lee, T. J.; Ryu, C. K.; Soo, Y. S.; Kim, J. C. $\mathrm{CO}_{2}$ absorption and regeneration of alkali metal-based solid sorbents. Catal. Today 2006, 111 (3-4), 385-390.

(210) Lee, S. C.; Chae, H. J.; Lee, S. J.; Choi, B. Y.; Yi, C. K.; Lee, J. B.; Ryu, C. K.; Kim, J. C. Development of regenerable MgO-based sorbent promoted with $\mathrm{K}_{2} \mathrm{CO}_{3}$ for $\mathrm{CO}_{2}$ capture at low temperatures. Environ. Sci. Technol. 2008, 42 (8), 2736-2741.

(211) Li, L.; Li, Y.; Wen, X.; Wang, F.; Zhao, N.; Xiao, F. K.; Wei, W.; Sun, Y. H. $\mathrm{CO}_{2}$ Capture over $\mathrm{K}_{2} \mathrm{CO}_{3} / \mathrm{MgO} / \mathrm{Al}_{2} \mathrm{O}_{3}$ Dry Sorbent in a Fluidized Bed. Energy Fuels 2011, 25 (8), 3835-3842.

(212) Li, L.; Wen, X.; Fu, X.; Wang, F.; Zhao, N.; Xiao, F. K.; Wei, W.; Sun, Y. H. $\mathrm{MgO} / \mathrm{Al}_{2} \mathrm{O}_{3}$ Sorbent for $\mathrm{CO}_{2}$ Capture. Energy Fuels 2010, 24, 5773-5780.

(213) Han, K. K.; Zhou, Y.; Chun, Y.; Zhu, J. H. Efficient MgObased mesoporous $\mathrm{CO}_{2}$ trapper and its performance at high temperature. J. Hazard. Mater. 2012, 203, 341-347.

(214) Han, S. J.; Bang, Y.; Kwon, H. J.; Lee, H. C.; Hiremath, V.; Song, I. K.; Seo, J. G. Elevated temperature $\mathrm{CO}_{2}$ capture on nanostructured $\mathrm{MgO}-\mathrm{Al}_{2} \mathrm{O}_{3}$ aerogel: Effect of $\mathrm{Mg} / \mathrm{Al}$ molar ratio. Chem. Eng. J. 2014, 242, 357-363.

(215) Gupta, H.; Fan, L.-S. Carbonation-Calcination Cycle Using High Reactivity Calcium Oxide for Carbon Dioxide Separation from Flue Gas. Ind. Eng. Chem. Res. 2002, 41 (16), 4035-4042.

(216) Li, Z. S.; Cai, N. S.; Huang, Y. Y.; Han, H. J. Synthesis, experimental studies, and analysis of a new calcium-based carbon dioxide absorbent. Energy Fuels 2005, 19 (4), 1447-1452.

(217) Li, Z. S.; Cai, N. S.; Huang, Y. Y. Effect of preparation temperature on cyclic $\mathrm{CO}_{2}$ capture and multiple carbonationcalcination cycles for a new Ca-based $\mathrm{CO}_{2}$ sorbent. Ind. Eng. Chem. Res. 2006, 45 (6), 1911-1917.

(218) Martavaltzi, C. S.; Lemionidou, A. A. Parametric Study of the $\mathrm{CaO}-\mathrm{Ca}_{12} \mathrm{Al}_{14} \mathrm{O}_{33}$ Synthesis with Respect to High $\mathrm{CO}_{2}$ Sorption Capacity and Stability on Multicycle Operation. Ind. Eng. Chem. Res. 2008, 47 (23), 9537-9543.

(219) Martavaltzi, C. S.; Lemonidou, A. A. Development of new $\mathrm{CaO}$ based sorbent materials for $\mathrm{CO}_{2}$ removal at high temperature. Microporous Mesoporous Mater. 2008, 110 (1), 119-127.

(220) Wu, S. F.; Li, Q. H.; Kim, J. N.; Yi, K. B. Properties of a nano $\mathrm{CaO} / \mathrm{Al}_{2} \mathrm{O}_{3} \mathrm{CO}_{2}$ sorbent. Ind. Eng. Chem. Res. 2008, 47 (1), 180184.

(221) Florin, N. H.; Blamey, J.; Fennell, P. S. Synthetic CaO-Based Sorbent for $\mathrm{CO}_{2}$ Capture from Large-Point Sources. Energy Fuels 2010, 24, 4598-4604.

(222) Florin, N.; Fennell, P. Synthetic CaO-based Sorbent for $\mathrm{CO}_{2}$ Capture. Energy Procedia 2011, 4, 830-838.

(223) Mastin, J.; Aranda, A.; Meyer, J. New synthesis method for $\mathrm{CaO}$-based synthetic sorbents with enhanced properties for hightemperature $\mathrm{CO}_{2}$ capture. Energy Procedia 2011, 4, 1184-1191.

(224) Luo, C.; Zheng, Y.; Ding, N.; Zheng, C. G. Enhanced cyclic stability of $\mathrm{CO}_{2}$ adsorption capacity of $\mathrm{CaO}$-based sorbents using $\mathrm{La}_{2} \mathrm{O}_{3}$ or $\mathrm{Ca}_{12} \mathrm{Al}_{14} \mathrm{O}_{33}$ as additives. Korean J. Chem. Eng. 2011, 28 (4), $1042-1046$.

(225) Zhou, Z. M.; Qi, Y.; Xie, M. M.; Cheng, Z. M.; Yuan, W. K. Synthesis of $\mathrm{CaO}$-based sorbents through incorporation of alumina/ aluminate and their $\mathrm{CO}_{2}$ capture performance. Chem. Eng. Sci. 2012, $74,172-180$.

(226) Broda, M.; Muller, C. R. Synthesis of Highly Efficient, CaBased, $\mathrm{Al}_{2} \mathrm{O}_{3}$-Stabilized, Carbon Gel-Templated $\mathrm{CO}_{2}$ Sorbents. $\mathrm{Adv}$. Mater. 2012, 24 (22), 3059-3064.

(227) Koirala, R.; Reddy, G. K.; Smirniotis, P. G. Single Nozzle Flame-Made Highly Durable Metal Doped Ca-Based Sorbents for $\mathrm{CO}_{2}$ Capture at High Temperature. Energy Fuels 2012, 26 (5), 31033109 .
(228) Zhang, M.; Peng, Y.; Sun, Y.; Li, P.; Yu, J. Preparation of CaO$\mathrm{Al}_{2} \mathrm{O}_{3}$ sorbent and $\mathrm{CO}_{2}$ capture performance at high temperature. Fuel 2013, 111, 636-642.

(229) Kierzkowska, A. M.; Poulikakos, L. V.; Broda, M.; Müller, C. R. Synthesis of calcium-based, $\mathrm{Al}_{2} \mathrm{O}_{3}$-stabilized sorbents for $\mathrm{CO}_{2}$ capture using a co-precipitation technique. Int. J. Greenhouse Gas Control 2013, 15, 48-54.

(230) Lu, H.; Khan, A.; Pratsinis, S. E.; Smirniotis, P. G. FlameMade Durable Doped-CaO Nanosorbents for $\mathrm{CO}_{2}$ Capture. Energy Fuels 2009, 23 (1), 1093-1100.

(231) Koirala, R.; Gunugunuri, K. R.; Pratsinis, S. E.; Smirniotis, P. G. Effect of Zirconia Doping on the Structure and Stability of CaOBased Sorbents for $\mathrm{CO}_{2}$ Capture during Extended Operating Cycles. J. Phys. Chem. C 2011, 115 (50), 24804-24812.

(232) Broda, M.; Müller, C. R. Sol-gel-derived, CaO-based, $\mathrm{ZrO}_{2-}$ stabilized $\mathrm{CO}_{2}$ sorbents. Fuel 2014, 127, 94-100.

(233) Reddy, G. K.; Quillin, S.; Smirniotis, P. Influence of the Synthesis Method on the Structure and $\mathrm{CO}_{2}$ Adsorption Properties of $\mathrm{Ca} / \mathrm{Zr}$ Sorbents. Energy Fuels 2014, 28 (5), 3292-3299.

(234) Wang, B.; Song, X.; Wang, Z.; Zheng, C. Preparation and Application of the Sol-Gel Combustion Synthesis-Made $\mathrm{CaO} /$ $\mathrm{CaZrO}_{3}$ Sorbent for Cyclic $\mathrm{CO}_{2}$ Capture Through the Severe Calcination Condition. Chin. J. Chem. Eng. 2014, 22 (9), 991-999.

(235) Zhao, M.; Bilton, M.; Brown, A. P.; Cunliffe, A. M.; Dvininov, E.; Dupont, V.; Comyn, T. P.; Milne, S. J. Durability of $\mathrm{CaO}-\mathrm{CaZrO}_{3}$ Sorbents for High-Temperature $\mathrm{CO}_{2}$ Capture Prepared by a Wet Chemical Method. Energy Fuels 2014, 28 (2), 1275-1283.

(236) Buelens, L. C.; Poelman, H.; Detavernier, C.; Marin, G. B.; Galvita, V. V. $\mathrm{CO}_{2}$ sorption properties of $\mathrm{Li}_{4} \mathrm{SiO}_{4}$ with a $\mathrm{Li}_{2} \mathrm{ZrO}_{3}$ coating. J. $\mathrm{CO}_{2}$ Utilization 2019, under revision.

(237) Kierzkowska, A. M.; Pacciani, R.; Müller, C. R. CaO-Based $\mathrm{CO}_{2}$ Sorbents: From Fundamentals to the Development of New, Highly Effective Materials. ChemSusChem 2013, 6 (7), 1130-1148.

(238) Bhatta, L. K. G.; Subramanyam, S.; Chengala, M. D.; Olivera, S.; Venkatesh, K. Progress in hydrotalcite like compounds and metalbased oxides for $\mathrm{CO}_{2}$ capture: a review. J. Cleaner Prod. 2015, 103, $171-196$.

(239) Dou, B. L.; Wang, C.; Song, Y. C.; Chen, H. S.; Jiang, B.; Yang, M. J.; Xu, Y. J. Solid sorbents for in-situ $\mathrm{CO}_{2}$ removal during sorption-enhanced steam reforming process: A review. Renewable Sustainable Energy Rev. 2016, 53, 536-546.

(240) Memon, M. Z.; Zhao, X.; Sikarwar, V. S.; Vuppaladadiyam, A. K.; Milne, S. J.; Brown, A. P.; Li, J.; Zhao, M. Alkali Metal $\mathrm{CO}_{2}$ Sorbents and the Resulting Metal Carbonates: Potential for Process Intensification of Sorption-Enhanced Steam Reforming. Environ. Sci. Technol. 2017, 51 (1), 12-27.

(241) Gao, W. L.; Zhou, T. T.; Gao, Y. S.; Louis, B.; O’Hare, D.; Wang, Q. Molten salts-modified $\mathrm{MgO}$-based adsorbents for intermediate-temperature $\mathrm{CO}_{2}$ capture: A review. J. Energy Chem. 2017, 26 (5), 830-838.

(242) Samanta, A.; Zhao, A.; Shimizu, G. K. H.; Sarkar, P.; Gupta, R. Post-Combustion $\mathrm{CO}_{2}$ Capture Using Solid Sorbents: A Review. Ind. Eng. Chem. Res. 2012, 51 (4), 1438-1463.

(243) Yang, H.; Xu, Z.; Fan, M.; Gupta, R.; Slimane, R. B.; Bland, A. E.; Wright, I. Progress in carbon dioxide separation and capture: $A$ review. J. Environ. Sci. 2008, 20 (1), 14-27.

(244) Wang, J.; Huang, L.; Yang, R.; Zhang, Z.; Wu, J.; Gao, Y.; Wang, Q.; O'Hare, D.; Zhong, Z. Recent advances in solid sorbents for $\mathrm{CO}_{2}$ capture and new development trends. Energy Environ. Sci. 2014, 7 (11), 3478-3518.

(245) Winter, M. Web Elements; The University of Sheffield and Web Elements Ltd.

(246) Abbott, L. S. Process of and apparatus for producing hydrogen. US1345905A, November 6th, 1915, 1920.

(247) Marshall, J. W. H. Method for the production of hydrogen. US2198560A, April 29th 1938, 1940.

(248) Barr, F. T. Production of hydrogen. US2449635A, March 19th 1943 (Canada), 1948. 
(249) Dahl, I. M.; Blom, R. Chemical Looping Combustion. US8672671B2, March 18, 2014, 2014.

(250) Reuter, G.; Schnabel, W.; Lausch, H. Process of calcining limestone in a rotary kiln. US4259081A, March 31st, 1981, 1981.

(251) Zhao, Z.; Chen, T.; Ghoniem, A. F. Rotary Bed Reactor for Chemical-Looping Combustion with Carbon Capture. Part 2: Base Case and Sensitivity Analysis. Energy Fuels 2013, 27 (1), 344-359.

(252) Zhao, Z.; Chen, T.; Ghoniem, A. F. Rotary Bed Reactor for Chemical-Looping Combustion with Carbon Capture. Part 1: Reactor Design and Model Development. Energy Fuels 2013, 27 (1), 327343.

(253) Johansson, E.; Mattisson, T.; Lyngfelt, A.; Thunman, H. A $300 \mathrm{~W}$ laboratory reactor system for chemical-looping combustion with particle circulation. Fuel 2006, 85 (10), 1428-1438.

(254) Johansson, M.; Mattisson, T.; Lyngfelt, A. Use of NiO/ $\mathrm{NiAl}_{2} \mathrm{O}_{4}$ particles in a $10 \mathrm{~kW}$ chemical-looping combustor. Ind. Eng. Chem. Res. 2006, 45 (17), 5911-5919.

(255) Linderholm, C.; Abad, A.; Mattisson, T.; Lyngfelt, A. $160 \mathrm{~h}$ of chemical-looping combustion in a $10 \mathrm{~kW}$ reactor system with a NiObased oxygen carrier. Int. J. Greenhouse Gas Control 2008, 2 (4), 520530.

(256) Rydén, M.; Jing, D.; Källén, M.; Leion, H.; Lyngfelt, A.; Mattisson, T. CuO-Based Oxygen-Carrier Particles for ChemicalLooping with Oxygen Uncoupling - Experiments in Batch Reactor and in Continuous Operation. Ind. Eng. Chem. Res. 2014, 53 (15), $6255-6267$.

(257) Lyngfelt, A.; Leckner, B. A $1000 \mathrm{MW}_{\text {th }}$ boiler for chemicallooping combustion of solid fuels - Discussion of design and costs. Appl. Energy 2015, 157, 475-487.

(258) Mattisson, T.; Keller, M.; Linderholm, C.; Moldenhauer, P.; Rydén, M.; Leion, H.; Lyngfelt, A. Chemical-looping technologies using circulating fluidized bed systems: Status of development. Fuel Process. Technol. 2018, 172, 1-12.

(259) Adanez, J.; Gayan, P.; Celaya, J.; de Diego, L. F.; GarciaLabiano, F.; Abad, A. Chemical looping combustion in a $10 \mathrm{~kW}_{\text {th }}$ prototype using a $\mathrm{CuO} / \mathrm{Al}_{2} \mathrm{O}_{3}$ oxygen carrier: Effect of operating conditions on methane combustion. Ind. Eng. Chem. Res. 2006, 45 (17), 6075-6080.

(260) Hanak, D. P.; Anthony, E. J.; Manovic, V. A review of developments in pilot-plant testing and modelling of calcium looping process for $\mathrm{CO}_{2}$ capture from power generation systems. Energy Environ. Sci. 2015, 8 (8), 2199-2249.

(261) Marx, K.; Bolhar-Nordenkampf, J.; Proll, T.; Hofbauer, H. Chemical looping combustion for power generation-Concept study for a $10 \mathrm{MW}_{\text {th }}$ demonstration plant. Int. J. Greenhouse Gas Control 2011, 5 (5), 1199-1205.

(262) Arias, B.; Diego, M. E.; Abanades, J. C.; Lorenzo, M.; Diaz, L.; Martínez, D.; Alvarez, J.; Sánchez-Biezma, A. Demonstration of steady state $\mathrm{CO}_{2}$ capture in a $1.7 \mathrm{MW}_{\text {th }}$ calcium looping pilot. Int. J. Greenhouse Gas Control 2013, 18, 237-245.

(263) Chang, M. H.; Huang, C. M.; Liu, W. H.; Chen, W. C.; Cheng, J. Y.; Chen, W.; Wen, T. W.; Ouyang, S.; Shen, C. H.; Hsu, H. W. Design and Experimental Investigation of Calcium Looping Process for 3-kW $\mathrm{kW}_{\mathrm{th}}$ and 1.9- $\mathrm{MW}_{\mathrm{th}}$ Facilities. Chem. Eng. Technol. 2013, 36 (9), 1525-1532.

(264) Dieter, H.; Hawthorne, C.; Zieba, M.; Scheffknecht, G. Progress in Calcium Looping Post Combustion $\mathrm{CO}_{2}$ Capture: Successful Pilot Scale Demonstration. Energy Procedia 2013, 37, $48-56$.

(265) Kremer, J.; Galloy, A.; Strohle, J.; Epple, B. Continuous $\mathrm{CO}_{2}$ Capture in a $1-\mathrm{MW}_{\text {th }}$ Carbonate Looping Pilot Plant. Chem. Eng. Technol. 2013, 36 (9), 1518-1524.

(266) Ströhle, J.; Junk, M.; Kremer, J.; Galloy, A.; Epple, B. Carbonate looping experiments in a $1 \mathrm{MW}_{\text {th }}$ pilot plant and model validation. Fuel 2014, 127, 13-22.

(267) Alonso, M.; Diego, M. E.; Pérez, C.; Chamberlain, J. R.; Abanades, J. C. Biomass combustion with in situ $\mathrm{CO}_{2}$ capture by $\mathrm{CaO}$ in a $300 \mathrm{~kW}_{\text {th }}$ circulating fluidized bed facility. Int. J. Greenhouse Gas Control 2014, 29, 142-152.
(268) Ströhle, J.; Orth, M.; Epple, B. Design and operation of a 1 $\mathrm{MW}_{\text {th }}$ chemical looping plant. Appl. Energy 2014, 113, 1490-1495.

(269) Sharma, R.; May, J.; Alobaid, F.; Ohlemuller, P.; Strohle, J.; Epple, B. Euler-Euler CFD simulation of the fuel reactor of a $1 \mathrm{MW}_{\text {th }}$ chemical-looping pilot plant: Influence of the drag models and specularity coefficient. Fuel 2017, 200, 435-446.

(270) Kim, K.; Yang, S.; Baek, J.-I.; Ryu, C. K.; Choi, M.; He, Y.; Shin, K.; Lee, G. New fabrication of mixed oxygen carrier for CLC: Sludge and scale from a power plant. Fuel 2013, 111, 496-504.

(271) Fan, L.; Li, F.; Ramkumar, S. Utilization of chemical looping strategy in coal gasification processes. Particuology 2008, 6 (3), 131142.

(272) Zeng, L.; Luo, S. W.; Sridhar, D.; Fan, L. S. Chemical looping processes - particle characterization, ionic diffusion-reaction mechanism and reactor engineering. Rev. Chem. Eng. 2012, 28 (1), 1-42.

(273) Tong, A.; Bayham, S.; Kathe, M. V.; Zeng, L.; Luo, S.; Fan, L.$S$. Iron-based syngas chemical looping process and coal-direct chemical looping process development at Ohio State University. Appl. Energy 2014, 113, 1836-1845.

(274) Rad, M. H.; Imanieh, M. H.; Nadarajah, A. Perovskite ceramics and recent experimental progress in reactor design for chemical looping combustion application. Chem. Pap. 2015, 69 (5), 627-649.

(275) Dahl, I. M.; Bakken, E.; Larring, Y.; Spjelkavik, A. I.; Håkonsen, S. F.; Blom, R. On the development of novel reactor concepts for chemical looping combustion. Energy Procedia 2009, 1 (1), 1513-1519.

(276) Hakonsen, S. F.; Blom, R. Chemical Looping Combustion in a Rotating Bed Reactor - Finding Optimal Process Conditions for Prototype Reactor. Environ. Sci. Technol. 2011, 45 (22), 9619-9626.

(277) Noorman, S.; Annaland, M. V.; Kuipers, H. Packed bed reactor technology for chemical-looping combustion. Ind. Eng. Chem. Res. 2007, 46 (12), 4212-4220.

(278) Heidebrecht, P.; Hertel, C.; Sundmacher, K. Conceptual analysis of a cyclic water gas shift reactor. Int. J. Chem. React. Eng. 2008, 6, 1495.

(279) Heidebrecht, P.; Sundmacher, K. Thermodynamic analysis of a cyclic water gas-shift reactor (CWGSR) for hydrogen production. Chem. Eng. Sci. 2009, 64 (23), 5057-5065.

(280) De Vos, Y.; Jacobs, M.; Van Der Voort, P.; Van Driessche, I.; Snijkers, F.; Verberckmoes, A. Optimization of spray dried attritionresistant iron based oxygen carriers for chemical looping reforming. Chem. Eng. J. 2017, 309, 824-839.

(281) De Vos, Y.; Jacobs, M.; Van Driessche, I.; Van der Voort, P.; Snijkers, F.; Verberckmoes, A. Processing and characterization of Febased oxygen carriers for chemical looping for hydrogen production. Int. J. Greenhouse Gas Control 2018, 70, 12-21.

(282) Adanez, J.; Abad, A.; Mendiara, T.; Gayan, P.; de Diego, L. F.; Garcia-Labiano, F. Chemical looping combustion of solid fuels. Prog. Energy Combust. Sci. 2018, 65, 6-66. 